\title{
Vofkori Mária \\ Társadalmi és gazdasági változások az udvarhelyszéki Havasalján a 17-18. században
}

\author{
A sorozatot szerkeszti \\ Dávid Gyula \\ Megjelent \\ a magyar Múvelődési és Közoktatási Minisztérium \\ támogatásával
}

ISBN 973-98579-0-6

AZ ERDÉLYI MÚZEUM-EGYESÜLET KIADÁSA

KOLOZSVÁR 1999 


\section{TARTALOM}

\section{Bevezetés}

Demográfiai változások az udvarhelyszéki Havasalján a 17-18. században
a) A vizsgált tájegység
b) A lakosság száma
c) Föld és ember

A havasaljai falvak társadalmi és gazdasági helyzete a 17-18. században

a) Társadalmi szerkezet

b) Havasalja falvainak gazdasága

\section{Függelék}

Úrbéri összeírások az 1713, 1785-86. és 1820. évekből 


\section{Bevezetés}

Társadalomtörténet, gazdaságtörténet, institúciótörténet - és ezt a sort még folytathatnánk tovább -, megannyi különböző megközelítésmódja a történeti fejlödés menetének. De bármennyire megosztott is a társadalomtudományok területe, valamennyi ugyanazt az egyetlen, egységes társadalmi valóságot elemzi. Ez a társadalmi valóság egy idő és tér által behatárolt organikus egység, melynek sajátos fejlődéstörténete van. Ezt hiánytalanul megismerni, bemutatni - ez lenne a társadalommal foglalkozó tudományok feladata, ez az a tökéletesség, amely felé valamennyi résztudomány - a maga területén - törekszik. Ami állandóan változó komponense ennek a folyamatnak, az a megközelités módja, mikéntje, a megközelítés maga. Minden diszciplína, részdiszciplína máshonnan és másképpen tekint a társadalmi valóságra, annak más és más komponenseit vizsgálja a maga sajátos eszközeivel. Megkockáztathatnánk azt a feltevést is, hogy a megközelítések száma végtelen, de maradjunk inkább annál a könnyebben elfogadható és ellenőrizhető kijelentésnél, hogy nem kevés. Ehhez a problémakörhöz kapcsolódik szorosan egy másik: a létjogosultságé. Vajon van-e létjogosultsága minden megközelítésnek, bármely megközelítésnek? Vajon bizonyos diszciplínák módszerei nem vezetnek-e a valóság, a társadalmi és történeti valóság túlzott felaprózásához, olyan felaprózáshoz, melynek következménye a részletek eluralkodása, a sematizmus, leegyszerüsítés? Vagy nem fog-e épp ennek az ellenkezője történni? Miért és meddig jó helytörténettel foglalkozni? Van-e létjogosultsága, értelme a tájegységek történetének?

Úgy véljük, hogy a 20. század történetírása és különösen az utolsó félévszázad historiográfiája megválaszolta ezeket a kérdéseket. Bármennyire megosztott is a társadalomtudományok területe, valamennyi ugyanazt az egyetlen, egységes társadalmi valóságot elemzi. Ennek a megállapításnak a jegyében született újjá a francia történetírás is. ${ }^{1}$ A sokat vitatott, sokat idézett Annales köré csoportosuló historikusok azt vallották, legyen az a megközelítés akár szociológiai, történeti-szociológiai, történeti-statisztikai, filozófiai (és még folytathatnánk a sort), és vizsgálja bár a társadalom sejtszerüen müködő komponensét, a családot vagy a nagyobb organizmusokat: a falut, vármegyét, fejedelemséget, valamennyi ugyanazt a célt követi. Amit így kimondtak, az nem volt más, mint a társadalomtudományok egységének hitvallása, amelytől eljutottak egészen az „embertudományok” egységének szentelt vitákig. ${ }^{2}$

Ezt az elméleti alapvetést tartjuk magunkénak. Amit müvelünk, helytörténet és tájtörténet, Paul Leuilliot szavaival élve: „lazított csomójú história”. ${ }^{3}$ Úgy véljük, hogy illeszkedik abba a vonulatba, amelyet a német történetírás Ortsgeschichte, Landesgeschichte, Territorialgeschichte címszókkal jelöl, ${ }^{4}$ valamint abba is, amely az angol történetírásban az úgynevezett

${ }^{1}$ Bloch, Marc: A történelem védelmében. Bp., 1974. 29-53; Baker, Alan R.H.: A történeti geográfia és az Annales történeti iskola közötti kapcsolatokra vonatkozó megjegyzések. Világtörténet, 1989. 3. sz. 6-29.

${ }^{2}$ Morazé, Charles: L'Histoire et l'unité des sciences de l'homme. Annales, 1968. 2. sz. 233-240. L. még Stahl, Henri H.: Sociologie „concretă” şi istorie. Revista de filozofie, 1968. 4. sz. 390.

${ }^{3}$ Leuilliot, Paul: Problèmes de la Recherche: V. - Défense et illustration de l'histoire locale. Annales, 1967. 22. évf. 1. sz. 755.

${ }^{4}$ Imreh István: Az EME honismereti-helytörténeti pályázatáról. Erdélyi Múzeum, 1993. 3-4. sz. 136143. 
cambridge-i csoport megalapítói, E.A. Wrigley és Peter Laslett, ${ }^{5}$ illetve H.L. Gray, W.G. Hoskins, A. Macfarlane, Margaret Spufford és mások nevéhez füződik. ${ }^{6}$

A történeti-társadalmi folyamatok nemcsak időben, hanem térben, földrajzi dimenziókban, helyhez kötötten is zajlanak. A hely meghatároz, de egyben be is határol egy társadalmat, keret, melytöl nem lehet elvonatkoztatni. A hely, ahol vizsgálódásaink folynak, sajátos fejlödéstörténete folytán kezelhető egy egységként, rész-egészként, az őt körülölelő - természeti, társadalmi - környezettel együtt egy életegészként, végül pedig mondjuk ki: egy tájegységként. Tudatában vagyunk minden ilyesfajta felosztás, elhatárolás többé-kevésbé önkényes voltának. A résznek a történeti-társadalmi valóság szövevényes egészéből való kiragadása nem is lehet más. De mivel az egész, annak müködési mechanizmusa csak a rész pontos ismerete által válik megközelíthetővé, olyan folyamat ez, amelyre a vizsgálódó, a kutató s így a tudomány is módszerei által rákényszerül.

A résznek, rész-egésznek, egy tájegységnek a kiválasztása mégsem teljesen önkényes. Már a rész-egész kifejezés önmagában szól erről, nemcsak sejtetve, hanem kimondva azt, hogy minden, amit ezzel meg lehet jelölni, valami közöset, valami felismerhetöt is hordoz, hordozza ugyanazt a - nem pejoratív értelemben vett - bélyeget, megjegyzettséget. Ha az általunk vizsgált tájegység esetében első látásra fel szeretnők ezt villantani, akkor - valódi és átvitt értelemben is - fentről, a havasról kell indulnunk.

Udvarhelyszék két legnagyobb erdőbirtokos falujának a Görgényi-havasokra és a Hargitára messze felnyúló erdői összeérnek valahol fenn a hegyen. A két falu: Oroszhegy és Zetelaka. Egymásnak szomszédai (Oroszhegynek keleti szomszédja Zetelaka, Zetelakának nyugati szomszédja Oroszhegy), de a két falu vonzáskörébe, azokkal életformát megosztva kisebb falvak is tartoznak; Oroszhegyhez még öt, Zetelakához három. A közigazgatás is kapocs köztük az évszázadok folyamán, de ennél jobban együvé tartozóvá teszi valamennyit a sovány föld, a kétszer soha nem kaszálható rét, a gyalog pár órányira fekvő város: Székelyudvarhely, de mindenekelött és -felett az erdő, ${ }^{7}$ amely behatárolja létüket egy bizonyos, jól meghatározott területre, és így eleve meghatározza az életviteli lehetőségeket, irányt szab a jövőbeni fejlődésnek. A tíz falut tekinthetjük és vizsgálhatjuk egy tájegységként. Már kutatásaink elején szembesültünk azonban a névadás kényszerével, ami elől nem lehet kitérni, ami szükséges kívánalom a forrásanyag ${ }^{8}$ könnyebb kezelhetősége szempontjából is, és ami itt részünkről még

${ }^{5}$ Cambridge Group for the History of Population and Social Structure. Tevékenységét 1964-ben kezdte meg E.A. Wrigley és Peter Laslett irányításával. Megalapítója is E.A. Wrigley.

${ }^{6}$ Lásd a felsorolt szerzők következő müveit: Wrigley, E.A. - Schofield, R.S.: The Population History of England 1541-1874. Cambridge, 1981; Laslett, Peter: The World We Have Lost. London, 1983; Uö: Household and Family in Past Time. Cambridge, 1972; Gray, H.L.: English Field Systems. Cambridge, 1915; Hoskins, W.G.: The Midland Peasant. London, 1965; Uö: The English Landscape. Oxford, 1958; Macfarlane, A.: The Origins of English Individualism. New York, 1978; Spufford, M.: Contrasting Communities: English Villages in the sixteenth and seventeenth Centuries. Cambridge, 1974.

${ }^{7}$ Bedő Albert: A magyar állam erdöségeinek gazdasági és kereskedelmi leírása. I. Bp., 1885. 513: „10 000 holdon felüli erdőbirtokok: Zetelaka község, Oroszhegy község."

${ }^{8}$ Alapforrások: Székely Oklevéltár. Szabó Károly-Szádeczky Lajos-Barabás Samu kiad. I-VIII. Kv. 1872-1934. (A továbbiakban SzOk1.); Udvarhelyszék Levéltára, az Országos Levéltár Kolozs megyei Igazgatóságán (A továbbiakban UszLt.) 1614-es conscriptio. Székely láda. 56. sz. (VIII. 1.); 1713. évi összeírások. Magyar Országos Levéltár (A továbbiakban MOL.) Vegyes conscriptiók. F. 49. folytatás a következö oldalon... 
annyira sem esetleges, mint a közigazgatási felosztások, egybesorolások bármelyike, ezek ugyanis nem mindig figyelnek az együvé, egy járásba, egy megyébe sorolt települések immanens jellegzetességeire, a földrajzi, gazdasági, néprajzi, jogi azonosságokat jelző tényezőkre, hanem a számba vehetőség, bizonyos dolgok könnyebb áttekinthetősége a szempontjuk. A tíz meggyőződésünk szerint együvé tartozó - falu mindegyike tipikusan havasaljai település, ennek megfelelö életmóddal, amelyet szintén nevezhetnénk havasaljainak. Egy falu nevét kiemelni és arról nevezni el a tájegységet, nem tartjuk szerencsésnek, úgy véljük tehát, az lehet a tájegység neve, ami legtöbbet elmond a tíz faluról együtt, de külön-külön is, ez pedig nem más, mint: Havasalja. Esetleg havasaljai falvak. De mivel havasaljai falvak még vannak Udvarhelyszéken, szeretnénk pontosítani: a Homoródtól keletre eső havasaljai falvakról van szó, amelyeket egy tájegységként ezentúl egyszerüen csak Havasaljának fogunk nevezni.

Amire nem törekszünk, az a falvak monografikus bemutatása. Havasalját egységként szemléljük, társadalmára egy sajátos, de nem egyedi életforma megtestesítőjeként tekintünk, célunk ennek modellértékü bemutatása. Mivel vizsgálódásunk főként népesedéstörténeti (demográfiai) jellegü, túlnyomórészt a történeti statisztika módszereit alkalmaztuk, minthogy a felhasznált forrásanyag milyensége és mennyisége ezt egyaránt megkövetelte. Demográfia, néptörténet, tájtörténet szorosan kapcsolódnak egymáshoz. Amire törekszünk, az nem egyszerü megszámlálás, nem „matematikai demográfia”, hanem a matematika segítségével megalkotott szociológiai gazdaság- és néptörténet. Meg kell keresnünk és ilyen összefüggésben kell vizsgálnunk a keretet, a régiót, az alakulatot ahhoz, hogy azt összevetve másokkal, rá tudjunk mutatni egy jelen esetben demográfiai - átlag körüli szóródás jelentéktelenségére vagy jelentékenységére.

Ez a könyv a kolozsvári Babeş-Bolyai Egyetemen 1997-ben megvédett doktori disszertációm kiadásra átdolgozott és rövidített változata.

Ezúton is szeretnék köszönetet mondani a disszertáció tudományos irányítójának, Magyari András professzornak, valamint opponenseimnek: Nicolae Bocşan professzornak, Simion Retegan és Szabó Miklós akadémiai fókutatóknak, akik szakmai észrevételeikkel hozzájárultak végleges formájának kialakításához.

Külön köszönet illeti Imreh Istvánt, egykori tanáromat, a székely faluközösségek tudós kutatóját, aki egész munkámban útbaigazítóm és tanácsadóm volt, továbbá Kiss András főlevéltárost, aki a levéltári kutatásaimhoz és a levéltári anyag sajtó alá rendezéséhez nyújtott messzemenő segítséget, valamint Bakács Bernadettet, a Magyar Országos Levéltár kutatóját az ottani kutatásaimban nyújtott eligazításért.

4 csomó; 1721. évi összeírások. MOL. Vegyes conscriptiók. F. 49. 8. csomó. 1722. évi összeírások. MOL. Vegyes conscriptiók. F. 49. 12. csomó; 1750-i országos összeírás. MOL. F. 50. 61. téka. 3. csomó; 1785-86-os úrbéri összeírás. MOL. F. 51. 23-24. csomó; Conscriptio Czirakyana. 1819-1820. MOL. F. 52. 118. kötet; Vö. Az elsö magyarországi népszámlálás (1784-1787). Szerk. Danyi Dezső és Dávid Zoltán. Bp. 1960; Trócsányi Zsolt: Erdélyi kormányhatósági levéltárak. Bp., 1973; - Uő: Erdélyi összeírások. A történeti statisztika forrásai. Bp., 1957. Szerk. Kovacsics József; Endes Miklós: Csík-, Gyergyó-, Kászonszékek (Csík megye) földjének és népének története 1918-ig. Bp., 1994. (Reprint.) 


\section{Demográfiai változások az udvarhelyszéki Havasalján a 17-18. században}

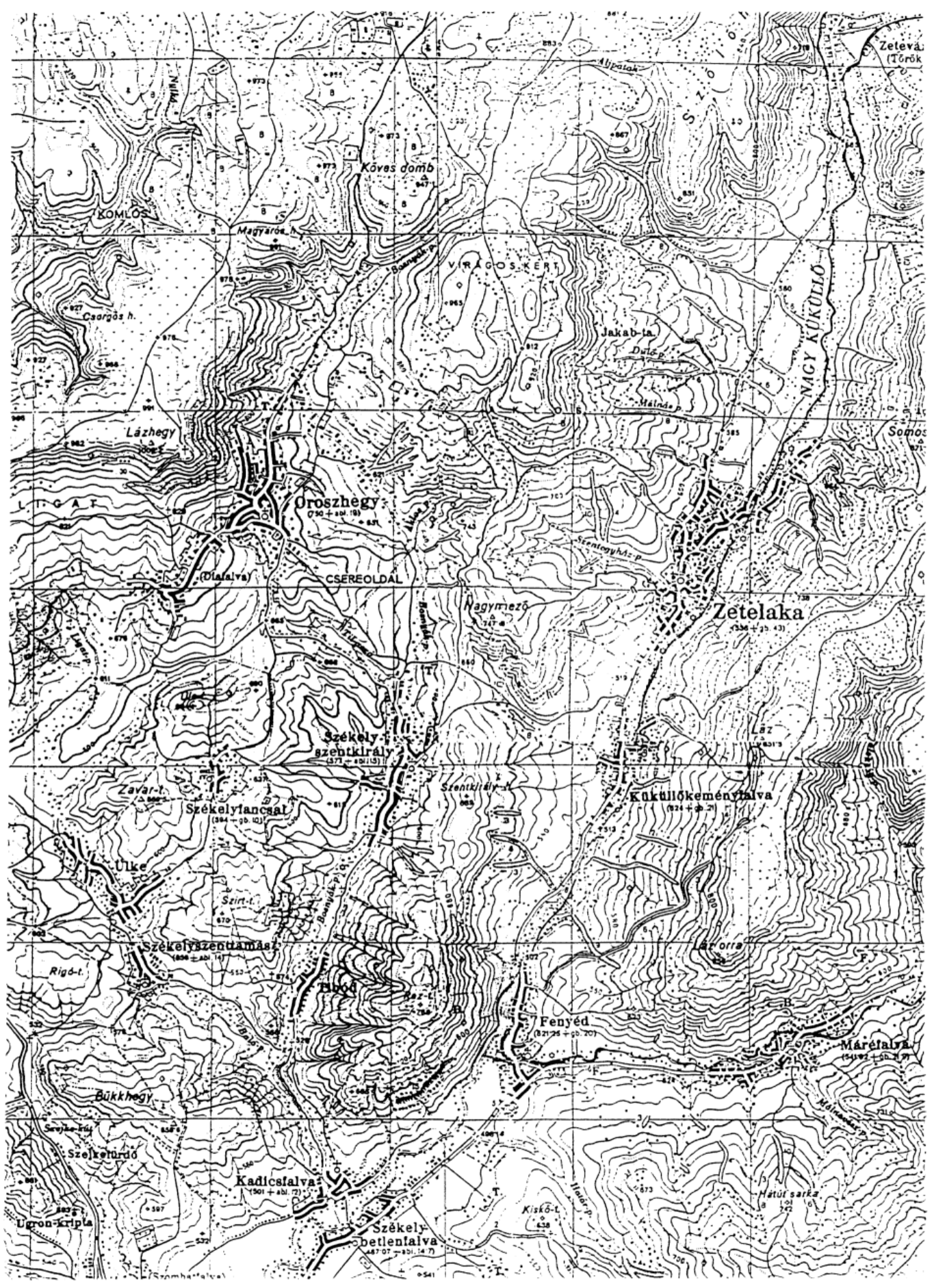




\section{a) A vizsgált tájegység}

Mielött rátérnénk a kimondottan népesedéstörténeti vizsgálódásra, szükségesnek tartjuk Havasalja tíz falvának földrajzi bemutatását, hisz amint már említettük, ez az a táj, ami nemcsak meghatároz, de be is határol egy életegészet, lévén, hogy a geohistóriai meghatározottság is fontos összetevője, eleme annak, amit úgy hívunk, hogy társadalmi valóság. A földrajzi bemutatás során a tájegységen belül egy tömbként kezeljük Oroszhegyet és azt az öt falut Szentkirályt, Ülkét, Fancsalt, Tibódot és Szenttamást -, melyekkel a századok folyamán nemcsak gazdaságilag, hanem közigazgatásilag is összetartozott, és hasonlóképpen Zetelakát, Küküllőkeményfalvát, Máréfalvát és Fenyédet, melyeket valamilyenféle csoportosításban a közös igazgatás, adminisztráció is mindig összefogott.

Oroszhegy tipikus havasaljai település a Hargita alján, a Deskő vagy Örhegy (1009 méter) déli lábánál, a Bosnyák és Ballé patak völgyföjében. Ma is községközpontja annak az öt falunak, melyekkel a századok folyamán gazdaságilag, közigazgatásilag összetartozott. Oroszhegytől délre, a Bosnyák patak mentén terül el Szentkirály és Tibód, a Ballé patak völgyében pedig ott sorjázik Szenttamás és Ülke. Fancsal Ülkétől északkeletre, a Ballé patak bal oldali mellékága, az Ülkén is átfolyó Fancsal pataka mentén terül el. ${ }^{9}$

Székelyudvarhelytől legtávolabb, tőle 12 km-re Oroszhegy fekszik. Tipikus havasaljai halmazfalu. Tengerszint feletti magassága 625-800 méter, de a vulkáni fennsíkon elterülő határrész eléri az 1000-1025 métert is. A Bosnyák patak menti két falu, Tibód és Szentkirály közül Szentkirály esik északabbra, közelebb Oroszhegyhez (4 km-re), de távolabb az anyavárostól, 9 kilométernyire tőle. Tengerszint feletti magassága 550-600 méter, míg az Udvarhelytől 6 kilométernyire eső Tibódé csak 525-530, mutatván, hogy Tibód „lennebb vagyon”. (Tibód kis sorfalu a Bosnyák patak bal partján, északi szomszédja pedig halmazfalu.)

A Ballé patak völgyi falvak közül a Ballé bal oldali mellékága, a Fancsal pataka menti Fancsal a legészakibb. Oroszhegytől csak 3,5 kilométernyire van, de a várostól 9 kilométer választja el. Halmaztelepülés, tengerszint feletti magassága 600-625 méter. Fancsaltól délnyugatra, Udvarhelytől 7 kilométer távolságra, 550-575 méter tengerszint feletti magasságban a Felszegre, Alszegre és Hegymegre oszló halmazfalu, Ülke következik, tőle délre, 5 kilométernyire a várostól, 525-550 méter magasságban az ugyancsak halmazfalu, Szenttamás található. ${ }^{10}$

A tájegység másik tömbjét a Nagy-Küküllő szeli át, ami Udvarhelyszék egyetlen bővizü folyója, lévén a többi - a két Homoród, a Nyikó, a Gagy - csak patakfolyó. A Nagy-Küküllő völgyében, annak felső, hegyvidéki szakaszán, 11 kilométerre Székelyudvarhelytől, 550-575 méter tengerszint feletti magasságban fekszik a tájegység vezérfalva - Zetelaka. Tipikus havasalji halmaztelepülés, nemcsak a tájegység, hanem egész Udvarhelyszék egyik legnagyobb községe. A viszonylag szük völgyben hosszan elnyúló falutestet keletről és északról 871 méter tengerszint feletti magasságú fennsík határolja (a Láz és a Somos tető), nyugatról pedig 750790 méter magas dombsor húzódik délre, a Küküllő felé. Belterületén számos patak ömlik a Nagy-Küküllőbe.

Zetelakától délre, a folyóvölgy egyre jobban szükülő medencéjében fekszik Küküllőkeményfalva. A nagy falutól, Zetelakától, melynek mintegy árnyékában élt, és amelyhez közigazgatásilag tartozott, 2, Udvarhelytől 9 kilométernyire van. Kis útifalu, kevés halmazos góccal a Felszegen, 525-530 méter tengerszint feletti magasságban. Sokat szenvedett a gyakori

\footnotetext{
${ }^{9}$ Lásd az előző térképet.

${ }^{10}$ Vofkori László: Udvarhely vármegye településföldrajza. Székelyudvarhely, 1996. (Kézirat.) 93-105.
} 
árvizektől. Főútja a Gyergyó felé vezető út, ennek mentén, Keményfalvától délre, a NagyKüküllő és a Fenyéd pataka találkozásánál fekszik Székelyudvarhely északkeleti peremközsége - Fenyéd. A város központjától csak 5 kilométer választja el; tengerszint feletti magassága 520540 méter. Úthatásra kialakult sorfalu. A Fenyéd patakán kívül számos patak pásztázza belterületét, környező magaslatai elérik a 856 métert is.

Fenyédtől keletre, a Fenyéd patak szük völgyében, a Cekend tető (820 m) lábánál húzódik az egykori Udvarhelyszék (a mai Hargita megye) egyik leghosszabb sorfaluja, Máréfalva. Udvarhelytöl 9 kilométernyire, a községközponttól, Fenyédtől 4 kilométerre, 540-560 méter tengerszint feletti magasságban fekszik. Tipikus havasaljai útifalu (utcás falu), csupán a templom körül mutat némi halmazos képet. Belterületén több patak is szolgáltat vizet, környező magasságai nem haladják meg számottevően a falut délről határoló Cekend tető magasságát. ${ }^{11}$

Nagyságrendileg, Zetelakát kivéve, valamennyi falu - Udvarhelyszék helységeire oly jellemzően - kis település. Zetelaka ma is Hargita megye négy legnagyobb községének egyike. Mind lakosságszámát, mind gazdasági erejét tekintve megelőzte a tájegység keleti tömbjének NagyKüküllő és Fenyéd pataka menti falvait. 1750-ben például kétszer több lelket számlál Keményfalvánál, több mint kétszer többet a tájegység másik tömbjének vezérfalujánál, Oroszhegynél és közel tizenkilencszer többet, mint Havasalja legkisebb, törpének tekinthető települése, Szenttamás. ${ }^{12}$

Oroszhegy is mindig megelőzte Szentkirályt lakosainak számát és gazdasági erejét illetően. Utánuk ezen a részen Ülke következett, mely a lakosság összlétszámát véve alapul négyszer kisebb Oroszhegynél, két és félszer Szentkirálynál, míg a három nagyságrendileg legkisebb, de egymáshoz hasonlatos falu, Tibód, Szenttamás és Fancsal esetében ez az arány hozzávetölegesen 1/12-ed és 1/7-ed. Nyilván, itt átlagokról és becslésekről van szó azért, hogy elöljáróban érzékeltessük a leglényegesebbet a falvak nagyságrend szerinti megoszlásáról, amely bizonyosféleképpen meghatározta egymáshoz való viszonyukat is. Minden korszaknak megvoltak ugyanis a sajátos nagyságrendbeli módosulásai, melyek, ha a lényegi, az előbbi becslésben jelzett különbségeket döntő módon nem is befolyásolták - Zetelaka, Oroszhegy mindig a tájegység két első falva maradt, Tibód pedig mindig a kicsik közé tartozott, időnként a legkisebb volt -, eredményeztek olyan változásokat, amelyekre figyelmeznünk kell, és amelyekkel részletesebben a továbbiakban foglalkozunk.

A falvak közti ilyetén nagyságrendbeli különbséget érzékelteti Orbán Balázs azzal, hogy müvében közel tíz oldalt szentel egyedül Oroszhegynek, ${ }^{13}$ négy teljes oldalt Zetelakának, ${ }^{14}$ míg filiáinak, Küküllőkeményfalvának és Fenyédnek összesen egy bekezdés jut. ${ }^{15}$ Nem méltatja ennél többre az Oroszhegyhez tartozó öt falut sem, azoknak is csak egy nagyobbacska bekezdést juttat, mondván, hogy „E falukról alig tudunk mást feljegyezni, mint azt, hogy Tiboldban Török Ferenc úr udvarán nemrég egy fazékot fordított ki a szekér kereke, melyben a

\footnotetext{
${ }^{11}$ Uo. 107-111.

${ }^{12}$ 1750. évi országos összeírás. MOL F. 50. 61. csomó. 7. tétel.

${ }^{13}$ Orbán Balázs: A Székelyföld leirása történelmi, régészeti, természetrajzi és népismei szempontból. I. kötet. Pest, 1868. 96-105. (Reprint: Bp., 1968. I-II.)

${ }^{14}$ Uo. 64-68.

${ }^{15}$ Uo. 64 .
} 
Triumviratustól kezdve egész Marcus Aur. Antoniusig minden consul és császárnak volt pénze..."16

„A pápai dézmák regesztrumában az 1332-dik év rovatában” csak Zetelaka és Szenttamás van bejegyezve. ${ }^{17}$ Küküllőkeményfalva Zetelakával alkotott egy egyházat, 1729-ben a zetelaki egyházi anyakönyvek jegyzik a Keményfalván születettek számát is. ${ }^{18} \mathrm{~A}$ máréfalviak és fenyédiek is sokáig egy templomba jártak, Máréfalva külön parokiális temploma ugyanis a hagyomány szerint az öreg Rákóczi György idejében épült fel. ${ }^{19}$ Szenttamás filiái lehettek Tibód, Fancsal, Szentkirály és Ülke. A pápai tizedjegyzék 1333. évi rovata már Oroszhegyet is jelzi „Dominicus Sacerdos de Uriczhegy” bejegyzéssel. Szentkirály hamar megszünhetett Szenttamás filiája lenni, mert ugyancsak Orbán Balázs az, aki a következöket írja: „Szentkirály régen anyamegyéje volt Oroszhegynek. 1606-ban e két falu még egy egyházmegye, csak azután válnak meg." 20

A 16. század és a 17. század eleje azonban már a reformáció időszaka. Bár távoli volt ez a vidék, elérték az egyházmegújítás hullámai. „... a 16-ik században annyira elterjedt volt a reformatio e vidéken is, hogy úgy Zetelakán, mint Oroszhegy és Szentkirályon is reformatus lelkészek voltak” - írja Orbán Balázs. „Zetelaki reformatus lelkészek közül tudjuk Baczoni Andrást, ki hivatalának nem felelvén meg, Rákóczi György által Mikes kérelmére mozdíttatott el, helyébe Oroszhegyi Péter jött, ezt Szentgyörgyi Dávid követte, de ez is olyan rosszul felelt meg hivatásának, hogy hívei által elúzetvén, azok visszatértek a katholikus hitre." ${ }^{21}$ A reformáció nem tud gyökeret verni Udvarhelyszéknek ezen a félreeső, hegyes vidékén. Napjainkban is egységesen katolikus vidék ez, ahol Tibód kivételével minden falunak külön temploma van. A tibódiak ma is Szenttamásra járnak misére.

A faluk határáról máshol, a későbbiekben fogunk szólani. Most annyit bocsátunk előre, hogy a hegyvidéki feltételek körülményei között a szántóhatár - amely felvezet a havasra - szük. Oroszhegy az egykori Udvarhelyszék egyik legmagasabban fekvő települése. Ami böviben jutott a tájegység falvainak, az az erdő. Mint már említettük, Oroszhegy és Zetelaka Udvarhelyszék két legnagyobb erdőbirtokosa volt. ${ }^{22}$

Bár vizsgálódásunk időbeli behatároltságának keretein kívül esik, mégis meg kell említenünk egy Oroszhegy, Zetelaka és Szentkirály vonatkozásában igen figyelemre méltó tényt. Ezt is csak elöljáróban tesszük, a későbbiekben részletesebben is szeretnénk foglalkozni vele, lévén ez a jelenség olyan szál a történeti kutatások bonyolult szerkezetü, sokszor gordiuszinak tünő csomójában, ami az utóbbi évtizedekben keltette föl igazán a kutatók érdeklődését. A 19-20. században mindhárom falu anyaközséggé vált oly módon, hogy lakóinak kirajzásából új települések születtek. Így jött létre Oroszhegy lakói egy részének szállásokra való „hátratelepedéséből” Varság, amely századunk elején már önálló település, továbbá Zetelaka „szórványai”:

\footnotetext{
${ }^{16}$ Uo.

${ }^{17}$ Uo. 65 .

${ }^{18}$ Csíkszeredai Állami Levéltár. F. 47. Egyházi anyakönyvek. 737-738.

${ }^{19}$ Dávid László: A középkori Udvarhelyszék müvészeti emlékei. Bukarest, 1981. 130-132, 203-204.

${ }^{20}$ Orbán Balázs: i.m. 64.

${ }^{21}$ Uo.

${ }^{22}$ Bedő Albert: i.m. 513. - Lásd még: A hitbizományi, valamint a községi és közbirtokossági birtokok területének és mívelési ágak szerinti megoszlásának kimutatása. Bp., 1894. 45. A zetelaki és oroszhegyi erdők 1894-ben a közbirtokossági erdők mintegy felét teszik ki.
} 
Zeteváralja, Ivó, Deság, Sikaszó és Küküllömezö, valamint többségében Szentkirály múlt század végi nyári szállásaiból Üknyéd. Azért többségében, mert itt azzal a viszonylag ritka jelenséggel állunk szemben, hogy Üknyéd nemcsak egy falu, nem kimondottan a szentkirályiak kirajzásából született. Bár ők vannak többségben, az üknyédiek között vannak Oroszhegyről származottak is, mi több, négy család zetelaki. Az egykori nyári szállásoknak tanyákká, majd önálló településekké való alakulása számos, eddig még megválaszolatlan kérdést vet fel. A ma Oroszhegy községközponthoz tartozó Üknyéd, melyet tulajdonképpen három falu „telepesei” hoztak létre, annyit már első látásra elárulni látszik, hogy Havasalja falvai valóban együvé tartoztak, egy tájegységet alkottak, és ennek az együvétartozásnak a módozatai, a mikéntje továbbra sem kerültek be a történeti kutatás látókörébe.

Ez az a táj, amely keretet ad egy életformának és a maga földrajzi sajátosságaival bizonyos mértékben meg is határozza, be is határolja azt. Ilyen sajátos tájegység nem egy van Erdélyben. Gondoljunk csak az Avasra, Hátszeg-vidékre (Țara Hațegului) vagy Fogaras-vidékre (Țara Făgăraşului). ${ }^{23}$ A faluközösség, amely alapsejtje valamennyinek, öriz bizonyos hasonló, mindenütt fellelhetö, általánosnak mondható hagyományokat az élet bármely szektorában, mégis mindegyik tájegység sajátos rész-egészként fejlödött a történelmi időben. Sajátos földrajzi feltételek szabta keretben, külön történeti, jogi, igazgatási hagyományokat alakítva, amelyek együttese egy életforma, azaz egy tájegység vonatkozásában: $a z$ életforma. Végső soron ez határozta meg a népesedéstörténetet is, keretet szabva a lakosság számának.

\section{b) A lakosság száma}

Adataink alapján népesedéstörténeti szempontból két kérdéskörre, illetve azok miértjeire kell válaszolnunk: a) Milyen a tájegységen belüli települések nagyságrendje és hogyan változott vagy változott-e ez egyáltalán a történelmi idő folyamán? b) Mit mutatnak a lakosság összlétszámát jelző népesedési mutatók? Csökkenést, növekedést, szinuszgörbe szerinti változást vagy épp stagnálást? Nyitott, minden újra fogékony, esetleg népesedésrobbanásra alkalmas rész-egészről van itt szó, vagy épp annak ellenkezőjéről, egy zárt, esetleg elzárt, hagyományba merevedett közösségröl?

a) Kezdjük a települések nagyságrendjével.

Havasalja lakossága a 17-18. század folyamán a következőképpen alakult ${ }^{24}$ :

(I.)

\begin{tabular}{|l|l|r|r|r|r|}
\hline & & $\mathbf{1 6 1 4}$ & $\mathbf{1 7 2 1}$ & $\mathbf{1 7 5 0}$ & $\mathbf{1 7 8 6}$ \\
\hline 1. & Fenyéd & 175 & 215 & 245 & 364 \\
\hline 2. & Máréfalva & 235 & 230 & 325 & 479 \\
\hline 3. & Küküllökeményfalva & 140 & 150 & 175 & 222 \\
\hline 4. & Zetelaka & 395 & 1030 & 1230 & 1597 \\
\hline 5. & Szenttamás & 55 & 60 & 65 & 78 \\
\hline
\end{tabular}

${ }^{23}$ R. Vuia: Ţara Hațegului şi regiunea pădurienilor. Studiu antropo-geografic şi etnografic. Cluj, 1926; Ştefan Meteş: Situaţia economică a românilor din Țara Făgăraşului. I. Cluj, 1935; Uő: Vieața agrară, economică a românilor din Ardeal şi Ungaria. I. Buc., 1921; D. Prodan: Problema iobăgiei în Transilvania. 1700-1848. Buc., 1989.

${ }^{24}$ UszLt. 1614-es conscriptio. Székely láda. 56. sz. (VIII. 1.); 1721. évi összeírások. MOL. Vegyes conscriptiók. F. 50. 8. csomó; Az első magyarországi népszámlálás (1784-1787). 362-367. (Ahhoz, hogy abszolút számokhoz jussunk, a conscriptiókban feltüntetett családfók számát beszoroztuk a már elfogadott és a szakirodalomban általánosan használt 5-ös szorzóval.) 


\begin{tabular}{|c|l|r|r|r|r|}
\hline & & $\mathbf{1 6 1 4}$ & $\mathbf{1 7 2 1}$ & $\mathbf{1 7 5 0}$ & $\mathbf{1 7 8 6}$ \\
\hline 6. & Fancsal & 85 & 65 & $(93)$ & 112 \\
\hline 7. & Szentkirály & 300 & 255 & 270 & 438 \\
\hline 8. & Tibód & 95 & 25 & 75 & 130 \\
\hline 9. & Ülke & 135 & 130 & 165 & 284 \\
\hline 10. & Oroszhegy & 365 & 410 & 545 & 868 \\
\hline & Összesen & $\mathbf{1 9 8 0}$ & $\mathbf{2 5 7 0}$ & $\mathbf{3 1 8 8}$ & $\mathbf{4 5 7 2}$ \\
\hline
\end{tabular}

Az egyes falvak százalékos megoszlása a tájegységen belül ${ }^{25}$ a következő:

(II.)

\begin{tabular}{|l|l|r|r|r|r|}
\hline & & $\mathbf{1 6 1 4}$ & $\mathbf{1 7 2 1}$ & $\mathbf{1 7 5 0}$ & $\mathbf{1 7 8 6}$ \\
\hline & & \multicolumn{1}{|c|}{$\%$} & $\%$ & $\%$ & $\%$ \\
\hline 1. & Fenyéd & 8,84 & 8,36 & 7,68 & 7,96 \\
\hline 2. & Máréfalva & 11,87 & 8,95 & 10,19 & 10,48 \\
\hline 3. & Küküllőkeményfalva & 7,07 & 5,83 & 5,50 & 4,85 \\
\hline 4. & Zetelaka & 19,95 & 40,08 & 38,58 & 34,93 \\
\hline 5. & Szenttamás & 2,78 & 2,33 & 2,05 & 1,70 \\
\hline 6. & Fancsal & 4,29 & 2,55 & 2,91 & 2,47 \\
\hline 7. & Szentkirály & 15,15 & 9,92 & 8,48 & 9,58 \\
\hline 8. & Tibód & 4,80 & 0,97 & 2,35 & 2,84 \\
\hline 9. & Ülke & 6,82 & 5,06 & 5,17 & 6,21 \\
\hline 10. & Oroszhegy & 18,43 & 15,95 & 17,09 & 18,98 \\
\hline & Összesen & $\mathbf{1 0 0 , 0 0}$ & $\mathbf{1 0 0 , 0 0}$ & $\mathbf{1 0 0 , 0 0}$ & $\mathbf{1 0 0 , 0 0}$ \\
\hline
\end{tabular}

A tájegység vezérfaluja, a nagyságrendileg legnagyobb település kétségtelenül a Nagy-Küküllö menti Zetelaka. Vezető szerepét a 18. században mindvégig megőrzi. 1721-ben a tíz falu lakosságának 40,08 százaléka él ebben a faluban, és ez az arány a század második felében is mindvégig 30 és 40 százalék között marad. A tájegység nyugati tömbjének legnagyobb faluja, Oroszhegy a lakosságszámot véve alapul a 17. század első felében még közel állhatott Zetelakához. A két nagy „erdőbirtokos” lélekszáma az 1614-es conscriptio tanúságtétele szerint csaknem megegyezik: Oroszhegy 365, Zetelaka pedig ennél alig több: 395 lelket számlál. A tájegységen belüli második helyét igen, de a lakosság összlétszámában való hasonlóságot (a mennyiségi mutatóknak ezt a közelségét) azonban az előbbi nem tudja megörizni. A Bosnyák és Ballé patakok menti falucsoport vezérfalva marad ugyan, de Havasalján Zetelaka után mindig csak a második, mégpedig olyan különbséggel, hogy míg Zetalakán az összlakosság 30-40 százaléka él a 18. században, addig Oroszhegyet csak annak 15-20 százaléka mondhatja lakóhelyéül. A fennmaradó nyolc falu nagyságrendileg három csoportra osztható: közepes, kicsi és törpe településekre.

Fenyéd, Máréfalva, Szentkirály - közepes falvak. A tájegységen belüli rangsorban Máréfalva és Szentkirály felváltva osztoznak a harmadik-negyedik helyen, Fenyéd mindig az ötödik. Átlagosan 45-95 családföt számlálnak és a tájegységen belül az összlakosság 7,68-10,58 százalékát képviselik. A hatodik és hetedik helyet elfoglaló Küküllőkeményfalva és Ülke már kicsi falvak (Keményfalva egészen a 18. század közepéig hatodik helyen van a tájegységben, csak az 1786-os népszámlálás alkalmával adja át helyét Ülkének, ahol ekkor 62 tényleges lakossal többet számlálnak össze). A század közepén 35 család él Keményfalván, 33 Ülkében, ez a tájegység lakosságának 5,50, illetve 5,17 százalékát jelentette. Ennél is kevesebbet tett ki az összlakosságból az a maroknyi ember, akik a három nagyon kicsinek számító faluban:

\footnotetext{
${ }^{25}$ Uo.
} 
Fancsalban, Tibódon és Szenttamáson laktak. Ha egy 16. századi átlagos méretű falu 15-20 házat számlált, akkor itt három törpetelepüléssel (hameau, Weiler) állunk szemben, ${ }^{26}$ ugyanis a családfők száma 1750-ig nem éri el a 20-at. Vannak olyan kirívó esetek is, mint az 1721-es tibódi népességszám, mikor a conscriptorok mindössze öt családföt írtak össze.

A családfók és a házak száma természetesen nem egyezik meg számszerüen, mint ahogy különbség van a conscriptiókban feltüntetett ház és lakás között is. Az 1750-es conscriptio tanúsága szerint például Szenttamáson 13 családfőnek 11 lakóháza van, egy libertinus és a faluban élő vagus nem rendelkezik lakóházzal. Ugyanakkor Tibódon 15 családnak is mindössze 11 lakóháza van, három jobbágy és egy jobbágy özvegye valószínüleg a máséban lakik. ${ }^{27} \mathrm{~A}$ század második felére sem változik alapvetően ez a helyzet. A rendelkezésünkre álló forrásnak, a II. József korabeli népszámlálásnak köszönhetően meg tudjuk mondani, hogy Tibódon 1786ban 27, Szenttamáson 17, Fancsalban 23 ház volt, és azt is, hogy egy házban átlagosan egy öt személyt számláló család lakhatott, de arról, hogy miképpen aránylik egymáshoz a családfők és házak, a családfök és lakások száma, ezúttal nem tudunk szólani, ${ }^{28}$ igaz, a települések nagyságrendjének vizsgálatánál ennek nincs is elsődleges fontossága. A házak száma azt mutatja, hogy a három falu, Fancsal, Tibód és Szenttamás a század viszonylatában valóban törpetelepülések. Házaik száma a század végén is alig haladja meg azt, ami a településtörténészek szerint a 16. században átlagnak, átlagfalunak számított. Szenttamás a tájegységen belül nagyságrendben majdnem mindig az utolsó, a tizedik, a legkisebb. (A 1720-as évek elején, a vészterhes években „veszíti el” Tibód javára utolsó helyezését.) A tájegység lakosságának átlagosan 2 százalékát képviseli. A nyolcadik és kilencedik helyen Tibód és Fancsal osztozik, felváltva. Itt - változóan - a tájegység lakosságának 2,50-2,90 százaléka él.

Zetelaka és Oroszhegy primátusát a tájegységen belül elsősorban gazdasági tényezők magyarázzák. Ha csak a köves, agyagos, négy ökörrel is nehezen szántható föld biztosította volna számukra a megélhetést, akkor nehezen tudták volna megtartani nagyságrendileg az első helyet a tájegységen belül. Ennek a két falunak azonban ott volt még az oly sokat emlegetett nagy kiterjedésű erdőbirtoka. (Az oroszhegyi és zetelaki erdők nemcsak a tájegységen belül, hanem széki viszonylatban is a legnagyobb erdőbirtokok voltak.) Ez a hatalmas kiterjedésü havas birtok jövedelempótló foglalkozást kínált. Oroszhegyi Mihály Deák már 1655-ben megénekli a fenyőfa és a zsindelycsinálás felettébb hasznos voltát, mondván, hogy egész Erdély és különösen városai:

Ez gazdag városok hová lennének el,

és mind az többi is Erdélyben ezekkel,

hogy ha nem éltetnék dészkával, sendellyel,

minden alkotmányok el pusztulna széllyel. ${ }^{29}$

Zetelaka, akárcsak Oroszhegy, valóságos „zsendelygyár” volt, rengeteg fürészmalommal a Nagy-Küküllőn, és azért tudta Oroszhegyet, a tájegység valamennyi falvát, de majdnem a szék valamennyi települését is megelőzni népességszám, földrajzi - és időnként gazdasági - nagyság

\footnotetext{
${ }^{26}$ Maksay Ferenc: A magyar falu középkori településrendje. Bp., 1971. 93-103. L. még Bloch, Marc: Les caractères originaux de l'histoire rurale française. 2. kiad. Paris, 1955.

${ }^{27}$ MOL. Gub. Trans. F. 50. 61. csomó. 3. tétel.

${ }^{28}$ Az elsö magyarországi népszámlálás (1784-1787). 362, 364, 366.

${ }^{29}$ Idézi Haáz Ferenc: Udvarhelyszéki famesterségek. Kolozsvár, 1942. 68-69.
} 
szempontjából, mert kiváltságos szabad székely település, privilegizált hely volt. ${ }^{30}$ Legelső írott kiváltságát, mely szerint beligazgatása és igazságszolgáltatása tekintetében önkormányzattal bírt, Bethlen Gábor fejedelemtől kapta 1622. szeptember 25-én. Az 1630. március 11-iki udvarhelyszéki székgyülésen kihirdetett privilégium a következőket foglalta magába: „E falu lakói oly kopár havasok közti vidéken laknak, hol mindennapi élelmöket is alig tudják megszerezni; azért öket és utódaikat, hogy inkább gyarapodhassanak, minden rovatal, adó, segély és kamarai nyereség, úgyszintén minden hadi szemle s rendes és rendkívüli hadi szolgálatok alól kivette $\mathrm{s}$ mentesítette oly föltétel alatt, hogy a fejedelem és fejedelmi utódai számára évenként 100000 zsendelyt szállítsanak Fejérvárra; és hogy jólétök növekedjék s ők az országnak nagyobb hasznára legyenek, következő szabadságokat és előjogokat adta nekik és utódaiknak: 1. Udvarhelyszék kapitányaitól, királybíráitól függetlenek legyenek s a fejedelem fejérvári udvara gondviselőjétől függjenek, de azoktól is csak e védlevél értelmében. Az udvarhelyszéki tiszteknek nyomozást tartani, tölük bírságot venni szabad ne legyen, közöttük büntetési joga csak a fejérvári gondviselőnek legyen. 2. Szabad egy bírót és 12 esküdtet választaniok szokásaik és rendszabályaik szerint. 3. 25 forintos perügyeket végleg elintézhetnek, ha ezt meghaladja az ügy, akkor is, de az elégedetlen fél Fejérvárra fölviheti. 4. Senki közülük magát jobbágyságra le nem kötheti, földjére jobbágyot nem telepíthet, közteher alól senkit kivonniok nem szabad; aki ezt tenné, fogassék el s csak kezességen bocsáttassék el; ha valaki elszöknék, öröksége s ingóságai, javai foglaltassanak el a község számára. 5. Udvarhelyszék tiszteinek bárminő fizetési vagy szolgálati rendeletei és kényszerítése ellen magukat oltalmazhassák, s e közbeni magukviseletért csak a fejérvári udvar gondviselöje elött legyenek feleletre vonhatók." 31 Zetelakát sok mindentől óvta, sok minden alól felmentette privilégiuma, bár ennek megtartása nem bizonyult egyszerünek az évszázadok folyamán. A szék sokszor megpróbálta maga alá vonni Zetelakát (és vele együtt Udvarhelyszék másik kiváltságos helyét, Oláhfalut is), a község pedig protestált, védte a privilégium által biztosított jussát. 1702-ben születik egy

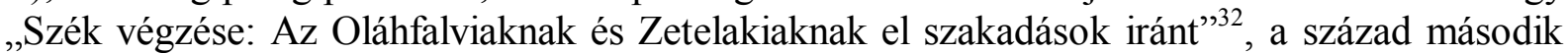
felében, 1777-ben a „Tekéntetes Nemes Szüntelen folyó Tábla” foglalkozik megint a privilégiumüggyel, a szék hozzá folyamodik ez ügyben, kérve, „hogy az Nemes Tábla azt meg írja, hogy Constitutio alatt lévő Privilegiumát Zetelaka úgy purificáltatta, hogy az Székkel egy helyre Contribuál; Oláhfalunak más az állapottya, mert eö in Transenta lévén Udvarhely és Csík Székek között minden Transentát Supportálnak, Zetelaka pedig szánt s vet, mind szintén Székünkbe akár mellyik falu, derék gazda lévén deszkát, sendelyt készít, melynek nagyobb részét in loco disztribálya, tehát kérése importunitás". ${ }^{33}$ Az egykor megadott és törvényesen soha vissza nem vont elöjog ellenére Zetelaka nem menekedhetett meg minden köztehertől. A „Nemes Udvarhelyszéki Tisztség” is gyakran követeli a részvételt a szék terheiben, utak, hidak megjavításában. 1791. április 26-án kelt levelében azzal fenyegeti meg az oláhfalvi magisztrátust a szék vezetősége, a „Nemes Udvarhelyszéki Tisztség”, hogy ha el nem küldi a 100 szál fenyőgerendát a Budvára alá felállítandó hídra, akkor ,azontul az Oláhfalvi Szekerek a Küküllőn lévő Hidakon sohult által nem bocsáttatnak, Minthogy a Zetelakiak már három Nagy Hidakra administrálván fát, arra nem eröltethetnek, másunnan pedig ki nem telik". Ilyen és

\footnotetext{
${ }^{30}$ Orbán Balázs: i.m. I. 65. L. még Benkő Elek - Demeter István - Székely Attila: Középkori mezőváros a Székelyföldön. Kolozsvár, 1997. 37-38.

31 Jakab Elek - Szádeczky Lajos: Udvarhely vármegye története a legrégibb idöktöl 1849-ig. Csíkszereda, 1994. 346-347. (Reprint.)

${ }^{32}$ UszLt. Közigazgatási akták. 1702. évi 3. sz. irattartó. 4.

${ }^{33}$ UszLt. Közigazgatási akták. 1777. évi 88. sz. irattartó.
} 
hasonló kérések okot szolgáltatnak a falvak - jelen esetben Oláhfalu és Zetelaka - közti kisebbnagyobb ellentétre, viszálykodásra is, egymásnak a széki hatóságoknál történő bepanaszolására. A privilégium, a mentesség megerősíttetése azonban mindennél fontosabb. Így 1791ben „A Zetelaki Communitas ide az Ország Gyülésére bé nyujtván alázatos Instantiáját, melyben kéri a Tekintetes Nemes Statusokat, hogy eö felsége eleibe terjesztvén ezen kérését, méltoztattnék Privilegiumokat confirmáltattni”. ${ }^{34}$ Az 1791-es országgyülés protocollumában Zetelaka mint taxás hely van feltüntetve, Bíró Miklós és Szegedi Pál küldöttek által képviseltetvén magát. ${ }^{35}$

Ugyancsak itt született végzés afelől, hogy mivel „a Regalisták [Hivatalosok] számából sok érdemes Hazafiak ki-hagyattak, és Regalissal nem hivattottak vólna. Ezek iránt végeztetett: hogy ezen tzikkelyben ki-jegyzett panaszlók közül Oláh-falu és Zetelaka, mivel ezeknek Követtyei az Ország Gyülésére az előtt-is meg-jelentek, adassék által a Fő Igazgató Tanátsnak, hogy számokra-is Regalis irattassék." ${ }^{\text {,3 }}$

Szigethy Gyula Mihály udvarhelyi kollégiumi professzor 1829-ben még úgy beszél Zetelakáról - és Oláhfaluról is - mint privilégiummal rendelkező „,véghelyekről”, amelyeknek külön „,királybírájuk”, 12 esküdtből álló magisztrátusuk van, és amelyek egészen „Fejérvárig lehordják a sendelyt, hisz fö foglalkozásuk a deszka-fürészelés és sendely-csinálás".

Tehát az erdő és a privilégium biztosította Zetelaka prosperitását, stabil első helyét a tájegységen belül demográfiai szempontból is. (Az 1722-es conscriptio is úgy jegyzi Zetelakát, mint: „Pagus Privilegiatus Zetelaka” ${ }^{37}$ ) A többi település, a másik kilenc falu közül egyedül Oroszhegy rendelkezik hasonló kiterjedésü erdőséggel, de előjoggal ő sem. A tájegység nagyságrendileg közepes és törpe falvai erdőből nem birtokolnak túl sokat. Az ülkeiek még a tüzifát sem mindig szerzik könnyen. 1785-ben az ülkei „béeskettettek” azt vallják, hogy „Tüzi és épület $\mathrm{Fa}$ az falunkhoz közél nintsen, de vagyon havasunk $\mathrm{s}$ abból élünk; melynek alkalmatlan az Utya és nehezen jutunk hozzá" ${ }^{38}$ Hasonlóképpen szólnak erdejükről a szenttamásiak is: „Tüzi fánk pedig ben az határunkban igen kevés vagyon, hanem az havason többecske vagyon, az honnan két napok alatt hozzuk meg a fánkat." 39

Mindezek mellett a települések nagyságrendjét a földrajzi tényezők is befolyásolták, hisz nem véletlen, hogy 1614-ben a legnagyobb számú apró, törpe település Udvarhelyszéken található.

\footnotetext{
${ }^{34}$ UszLt. Közigazgatási akták. 1791. évi 247. sz. irattartó.

${ }^{35}$ Uo.

${ }^{36}$ Uo.

${ }^{37}$ MOL. F. 49. Vegyes conscriptiók. 12. csomó. 7. sz. 87-88.

${ }^{38}$ MOL. F. 51. 1785-1786-i úrbéri összeírás. 24. csomó.

${ }^{39}$ Uo.
} 
A települések lélekszám szerinti megoszlása 1614-ben ${ }^{40}$ a következő:

(III.)

\begin{tabular}{|l|c|c|c|c|}
\hline & Udvarhelyszék & Marosszék & $\begin{array}{c}\text { Csík-Gyergyó- } \\
\text { Kászonszék }\end{array}$ & Háromszék \\
\hline 250 alatti lélekszám & 101 & 100 & 6 & 31 \\
\hline 250 feletti lélekszám & 29 & 16 & 42 & 63 \\
\hline Összesen & $\mathbf{1 3 0}$ & $\mathbf{1 1 6}$ & $\mathbf{4 8}$ & $\mathbf{9 4}$ \\
\hline
\end{tabular}

Udvarhelyszék és Marosszék a legtöbb kistelepüléssel rendelkező székek a Székelyföldön 1614-ben. Udvarhelyszék településeinek 77,69 százaléka kevesebb mint 50 családfôt - 250 lelket - számlál. Utánuk Háromszék következik 31 és Csík-Gyergyó-Kászonszék csak hat 250 léleknél kevesebbet számláló helységgel. (A családokat öt tagból állónak vettük.) Nagyságrend szerint tehát Havasalja falvai ekkor szervesen illeszkednek Udvarhelyszék keretébe és látható nagyságrendi eltéréseket mutatnak Háromszék, de különösképpen Csík-Gyergyó-Kászonszék falvaitól.

Hogy ez a kép változott-e a 18. század végére, arra, ha nem is pontos, de hozzávetőleges választ adhatnának a II. József-féle népszámlálás adatai, de az értékelés itt a vártnál is több nehézségbe ütközik. Először is az 1786-os számbavétel alól kivétettek azok a székely falvak, ahol határőrkatonaság volt, másodszor pedig az összeírás nem a régi, hagyományos vármegyei és széki beosztás szerint történt, hanem a II. József-féle új területi beosztás szerint, ${ }^{41}$ mely Marosszéket Küküllő megyéhez, Háromszéket Kászonszékkel együtt a Barcasághoz és FelsöFehér megye egyes részeihez csatolta, míg Csík- és Gyergyószékek Udvarhelyszékkel együtt alkották Udvarhely megyét. Ilyen körülmények között a régi területi egységek demográfiai és történeti nyomonkövetése nem kis nehézséget okoz. Összehasonlító adatként azonban szükségesnek látjuk megemlíteni, hogy az ekképp létrejött Udvarhely megye 168 települése közül 86-nak 300 alatti volt a lélekszáma, ami arra enged következtetni, hogy Udvarhelyszék megőrizte a túlnyomórészt kis településekből álló struktúráját. Ennek kapcsán nyilván felvetődik a kérdés: miért éppen Udvarhely- és Marosszéknek ilyen a településhálózata? Miért van épp ezekben a székekben olyan sok - napjainkig életképes - kis település? Udvarhelyszék vonatkozásában a válasz egy részét a földrajz, illetve a geohistória adja meg. A Csíki- és Gyergyóimedencétől eltérően, ahol nagy kiterjedésű, nehezebben védhető, nagyobb folyók által szabdalt sík területeket lát az arra utazó, Udvarhelyszéken nem talál mást, mint egy vulkáni fennsíkot és a Küküllő dombvidékét, melyet patakvölgyek szaggatnak, de bővizü, nagy folyója a NagyKüküllő kivételével tulajdonképpen nincs. Ez a patakok, patakfolyók - mint amilyen például a Nyikó, a két Homoród, a Gagy - által szaggatott, dimbes-dombos vidék a kis településeknek kedvez. A szék Havasaljához hasonló részein pedig, melyekre az erdő, a csapadékosság és a gyengén termő erdőtalaj jellemző, érdekes ellentét alakul ki a rendelkezésre álló, voltaképpen nagy kiterjedésü föld és a belőle irtás útján állandóan használhatóvá tett csekély hányad között, amely ezeken a helyeken többnyire a törpefalukat vagy az egészen szórt településrendet tette általánossá. ${ }^{42}$

${ }^{40}$ UszLt. Székely láda, 56. sz. (VIII. 1. Az 1614-es conscriptio). Vö. Imreh István- Pataki József: $A$ székely falu gazdasági-társadalmi szerkezete a XVI. század végén és a XVII. század elején. = Székely felkelés 1595-1596. Buk., 1979.

${ }^{41}$ Némethy Artúr: Magyarországi törvényhatóságok beosztásának változásai 1526 után. Statisztikai Közlemények, 1958. II. évf. 3-4. 111-112. L. még Thirring Gusztáv: Magyarország népessége II. József korában. Bp., 1938. 14-18.

${ }^{42}$ Maksay Ferenc: i.m. 103. 
b) Ahhoz, hogy egy árnyaltabb demográfiai képet adhassunk a tájegységről, különösen a lakosságszám 18. század eleji változásairól, szükségesnek tartottuk a következő táblázat beiktatását, melyben csak Havasaljának a Ballé és Bosnyák patakok menti, Oroszhegy környéki falvai szerepelnek, a Küküllő menti négy falu nem, ugyanis Fenyéd, Máréfalva, Keményfalva és Zetelaka kimaradt az 1713-as összeírásból.

Oroszhegy és környékének lakossága a 17-18. század folyamán a következőképpen alakult: ${ }^{43}$

(IV.)

\begin{tabular}{|l|l|r|r|r|r|r|}
\hline & & $\mathbf{1 6 1 4}$ & $\mathbf{1 7 1 3}$ & $\mathbf{1 7 2 2}$ & $\mathbf{1 7 5 0}$ & $\mathbf{1 7 8 6}$ \\
\hline 1. & Oroszhegy & 365 & 220 & 435 & 545 & 868 \\
\hline 2. & Szentkirály & 300 & 105 & 275 & 270 & 438 \\
\hline 3. & Ülke & 135 & 130 & 155 & 165 & 284 \\
\hline 4. & Fancsal & 85 & 70 & 75 & $(93)$ & 112 \\
\hline 5. & Tibód & 95 & 50 & 25 & 75 & 130 \\
\hline 6. & Szenttamás & 55 & 35 & 70 & 65 & 78 \\
\hline & Összesen & $\mathbf{1 0 3 5}$ & $\mathbf{6 1 0}$ & $\mathbf{1 0 3 5}$ & $\mathbf{( 1 2 1 3 )}$ & $\mathbf{1 9 1 0}$ \\
\hline
\end{tabular}

A 18. század elején 1614-hez viszonyítva a népesedési mutatók egyértelmü csökkenését figyelhetjük meg. Van falu, mint Szentkirály, amely lakosságának egyharmadát vesztette el a századfordulón és a század első évtizedeiben, van, amelyik közel felét, mint Tibód és Szenttamás. A következő évtizedben sem javult számottevően a helyzet, az 1722-es mutatók a stagnálásnál alig jeleznek egyebet. Minek köszönhető ez a demográfiai mélypont?

A századelő első olyan nagy eseménye, ami lakosságtizedelő lehetett volna, a II. Rákóczi Ferenc által vezetett kuruc szabadságharc volt. Hogy milyen mértékben tudható be ennek az első évtized végén bekövetkezett népességcsökkenés, ahhoz hasznos útmutatóul szolgál a kuruc hadseregnek 1704 őszén Radvánszky János parancsára történt összeírása. ${ }^{44}$ Ebben a lajstromban Oroszhegy 37, Szentkirály 29, Ülke 14, Fancsal 14 és Szenttamás 8 családfővel szerepel (Tibód hiányzik az összeírásból). Figyelembe véve, hogy ez a lajstrom csak a katonák számát adja és vannak már szép számmal (különböző okok miatt) mentesítettek is, a családfök száma reálisnak tünik; mivel viszont ez közelebb áll az 1614-es átlaghoz, mint az 1713-ashoz, arra következtethetünk, hogy a 17. század folyamán a népességszám meglehetősen stagnált, és a lakosságot nem az 1704 elötti harcok és zavargások tizedelték meg igazán. Ha itt figyelmezünk arra a közismert tényre is, hogy a háborúk (amennyiben a kérdéses terület nem hadszíntér) - természetesen itt a 17-18. századról van szó - nem annyira lakosságtizedelők, mint más természeti jellegű katasztrófák és járványok, lévén hogy csak az aktív férfilakosságot, a katonaköteleseket, tehát a lakosságnak csak egy rétegét érintik, míg az utóbbiak a lakosság teljes egészét, az összlakosságot, még helytállóbbnak tünik a következtetés, hogy nem a kuruclabanc harcoknak köszönhető a század eleji demográfiai csökkenés. Az 1711-ig tartó kuruc háborúnak a következményeként természetesen voltak a Székelyföldnek, így tájegységünk oroszhegyi részének is számottevőbb veszteségei, de még mielött a nagymajtényi síkon letörött volna a zászló, 1708 végén kelet felől behurcolták Erdélybe a pestist. „,.. bocsátá Isten mind Erdélyre, mind Magyarországra: a pusztító döghalált, melyhez hasonló soha Erdélyben nem volt, miolta ember kezdette lakni. Az elmúlt esztendőben Havasalföldiben Bukuresten kezdő-

${ }^{43} \mathrm{Az}$ 1614, 1750, 1786-ik évekre 1. a 16. sz. jegyzetet; 1713. évi összeírások. MOL. Vegyes conscriptiók. F. 49. 4. csomó. 12. tétel. 5-16; 1722. évi összeírások. MOL. Vegyes conscriptiók. F. 49. 12. csomó. 7. tétel. 89-100.

${ }^{44}$ Magyari András: II. Rákóczi Ferenc erdélyi hadserege. Bukarest-Kolozsvár, 1994. 422-423, 425. 
dék a pestis, oda Törökországból jött” ${ }^{\text {,45 }}$ - írja Cserei Mihály. 1710-ben még javában dühöng a járvány, az áldozatok száma egyre nő. „De mindenek felett a pestis grassála az egész országban” mondja ugyancsak Cserei Mihály erről az esztendőről is. „Elsőben a lovak, marhák, disznók, kutyák kezdének dögleni. Segesvárott, minekutána harmadfél ezeren, és Marosvásárhelyen is annyin megholtanak volna pestisben, Udvarhelyszéken tizennyolcezeren, Marosszéken szintén annyin." $\mathrm{Az}$ egyre nagyobb veszteségeket sáskajárás, „egyéb földi férgek” és marhavész dühöngése tetézte. ${ }^{47} \mathrm{~A}$ járvány harmadik éve 1711. A megholtak száma igen nagy. „Erdélyben még ugyan senki számba nem vette, mivel a pestis a mai napig is meg nem szünt, de gondolom nincs héja a százezernek, kik eddig a pestisben megholtanak, bizony fegyver miatt is sok ezeren hullottanak el. Rettenetes nagy ítélete Istennek rajtunk, mégsem térünk meg" ${ }^{, 48}$ - veszi számba és siratja az elpusztultakat Cserei uram. Ebben az évben sem jár egyedül a „mirigy”, mert „rettenetes baromdög”, nagy marhavész volt az egész országban.

A lakosságnak még nem is volt ideje kiheverni ennek a három évig tartó járványnak és a szatmári békének a következményeit, mert 1717 nyarán újból pestist hurcoltak be. Ehhez a csapáshoz még az is járult, hogy 1717 pünkösdjétől 1718 szeptemberéig nem volt eső. „,.. akkora éhség lett a mi Hazánkban, hogy az éhségtől kényszeríttetve némely erősebbek erőszakkal csoportosan gabonát s más eleségeket tulajdonosaiktól elraboltak, hárs, bikk, cserfák hajait, a két utóbbiaknak makkjait stb., különbözö gyökereket, nádat még polyvát is egyben roncsolva, és pogácsa vagy kenyér formára megsütve enni kénytelenek voltak [...] Szóval akkora éhség volt, hogy némely falvakban annyin holtak el éhség, mint pestis miatt." ${ }^{49}$ Maga a ragály pedig csak 1720-ban szünt meg. ${ }^{50}$

Ezek azok a tényezők, amelyek a 18. század eleji demográfiai mélypontot magyarázzák Havasalja Oroszhegyhez tartozó hat falvában. A lakosság lassan tér magához. Lassú, de stabil, nyomon követhető növekedést csak 1750 után kezd mutatni a tájegységnek ez a része.

Most azonban nézzük meg, hogy mi történt ugyanebben az időszakban, a 17. század fordulóján és a 18. század első két évtizedében a másik négy faluval, a Küküllő mentiekkel. Mint már említettük, az 1713-as összeírásban nem szerepelnek. Az 1704 őszén Radvánszky János parancsára összeírt erdélyi kuruc hadsereg lajstromába csak Fenyéd és Küküllökeményfalva vétetett fel: Fenyéd 15, Keményfalva 10 emberrel szerepel a lajstromban, ${ }^{51}$ Zetelaka és Máréfalva, a két „,nagyfalu” hiányzik belöle. Hogy későbben részt vettek-e az erdélyi kuruc hadseregben, annak harcaiban, nem tudhatjuk bizonyosan. Az összeírásból való kimaradásuk nem zárja ezt ki. Bizonyára voltak zetelaki, máréfalvi áldozatai is a kuruc szabadságharcnak, és „az országban grassáló pestis”, majd később a nagy szárazság őket sem kerülte el. Az 1721-es conscriptio szerint három falu - Fenyéd, Máréfalva, Küküllőkeményfalva - lakossága szám-

\footnotetext{
${ }^{45}$ Cserei Mihály: Erdély históriája [1661-1711]. Sajtó alá rendezte, bevezetővel és jegyzetekkel ellátta Bánkúti Imre. Bp., 1983. 432.

${ }^{46}$ Uo. 443.

${ }^{47}$ Réthly Antal: Időjárási események és elemi csapások Magyarországon 1701-1800-ig. Bp., 1970. 52.

${ }^{48}$ Cserei Mihály: i.m. 473.

${ }^{49}$ Réthly Antal: i.m. 71. Az idézet forrása: Benkő Károly: Csík, Gyergyó és Kászon leírása. Kolozsvár, 1853. 84.

${ }^{50}$ Ua. 88.

${ }^{51}$ Magyari András: i.m. 424.
} 
belileg stabilizálódást, lassú növekedést mutat. (Fenyéden 40-nel, Keményfalván 10-zel nőtt a lélekszám 1614-hez viszonyítva, Máréfalván pedig annyira állandósult, hogy öt híján elérte az akkori 235-ös lélekszámot.) Egyetlen kivétel, egyetlen rendhagyó eset - Zetelaka.

A tájegység kilenc falvának lélekszáma a conscriptiók bizonyságtétele szerint 1721-22-ben - a vészterhes évek, évtizedek után - valahol az 1614-es átlag körül mozog. Valamennyivel kevesebb, valamennyivel több annál, de az eltérés sehol nem számottevő. Ez természetes is, hiszen épp csak hogy elkezdődött a háborúk, mirigy, marhavész, sáskajárás és szárazság utáni újjáéledés. A lábadozás időszaka ez, az az idő, amikor még hallani a Cserei Mihályéhoz hasonló számbavétel feletti sirámokat. A veszteség még inkább jelen, mint múlt idejü. Egy falu a havasaljai tíz településböl másként viselkedik. Vagy nem vesztett olyan sokat, vagy gyorsabban épült. Zetelaka lakóinak száma 1721-re majdnem megháromszorozódott 1614-hez képest. (1614-ben 395 lelket számlált, míg 1721-ben 1030-at, 1722-ben 1080-at.)

A falu hiányzott 1704-ben az erdélyi kuruc hadsereg összeírásaiból, de a harcokban azért még részt vehetett. A századelői dögvész, marhavész, szárazság ugyan nem ismert határokat, kivételeket. Zetelaka hatalmas erdeje, hegyi fekvése, a lakosság erdei, havasi (nyári) szállásokra való felhúzódása magyarázhatja, hogy a pusztítás itt nem olyan méretü, mint másutt. Azt, hogy Zetelaka nem a környező falvak mértékében, azokhoz hasonlóan szenvedte meg, élte át a vészterhes időket, a 18. századból fennmaradt egyházi anyakönyvek is mutatják. ${ }^{52}$

Ezeknek megfelelően a születések száma Zetelakán 1705-1728 között a következőképpen alakult:

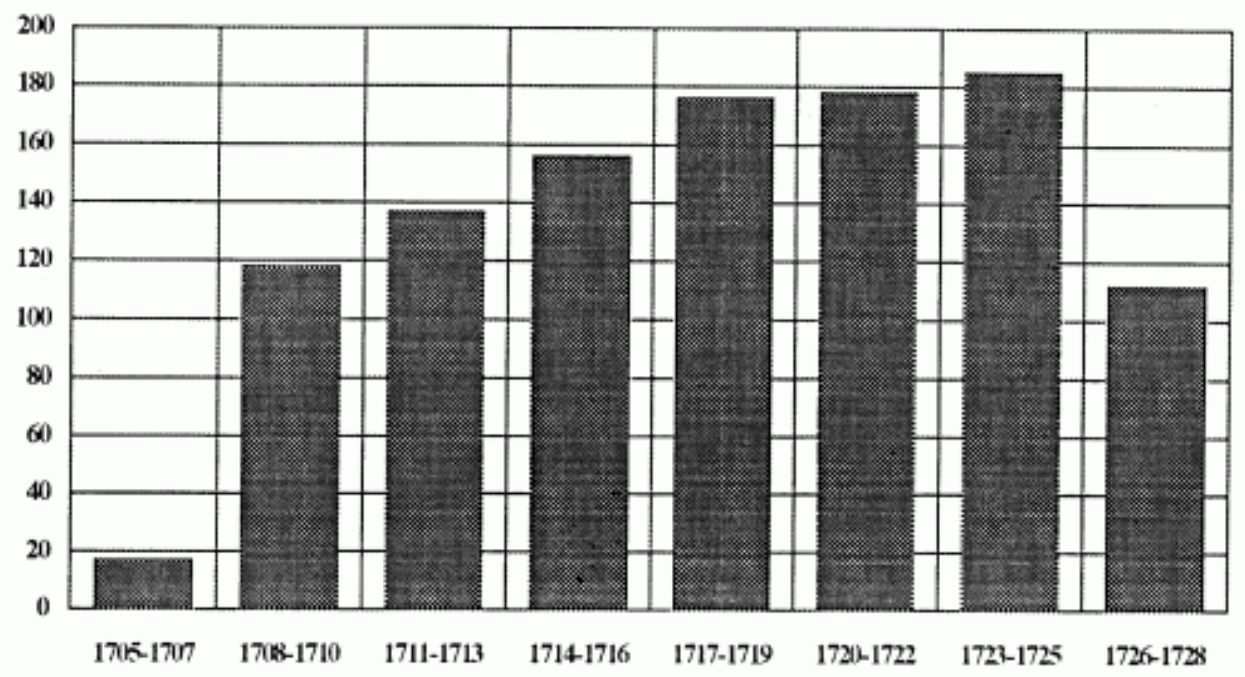

Látható, hogy a születések száma 1708-tól kezdve (ez a pestis behurcolásának éve) folyamatosan növekedö tendenciát mutat egészen 1725-ig. A 18. század első negyedének végén 1723-1725 között - a születések száma Zetelakán eléri a század eddigi legmagasabb szintjét, a 185-öt. Mivel a halálozások és esketések hiányosan vannak feljegyezve (az esketettek például csak 1719-től 1728-ig), népszaporulatot jelző mutatókat nem tudunk összeállítani. A születéseket viszont tovább tudjuk követni, egészen 1798-ig, a század végéig, azzal a kevés különbséggel, hogy 1729-től 1798-ig a zetelaki és küküllőkeményfalvi keresztelteket egyazon anyakönyvbe írták be. ${ }^{53}$

\footnotetext{
${ }^{52}$ Csíkszeredai Állami Levéltár. F. 47. Egyházi anyakönyvek. 737-738.

${ }^{53}$ Uo. A tájegység többi településének 18. századi - 19. század eleji egyházi anyakönyvei nem maradtak fenn.
} 
Ezek szerint a születések száma Zetelakán és Keményfalván 1729 és 1798 között a következöképpen alakult:

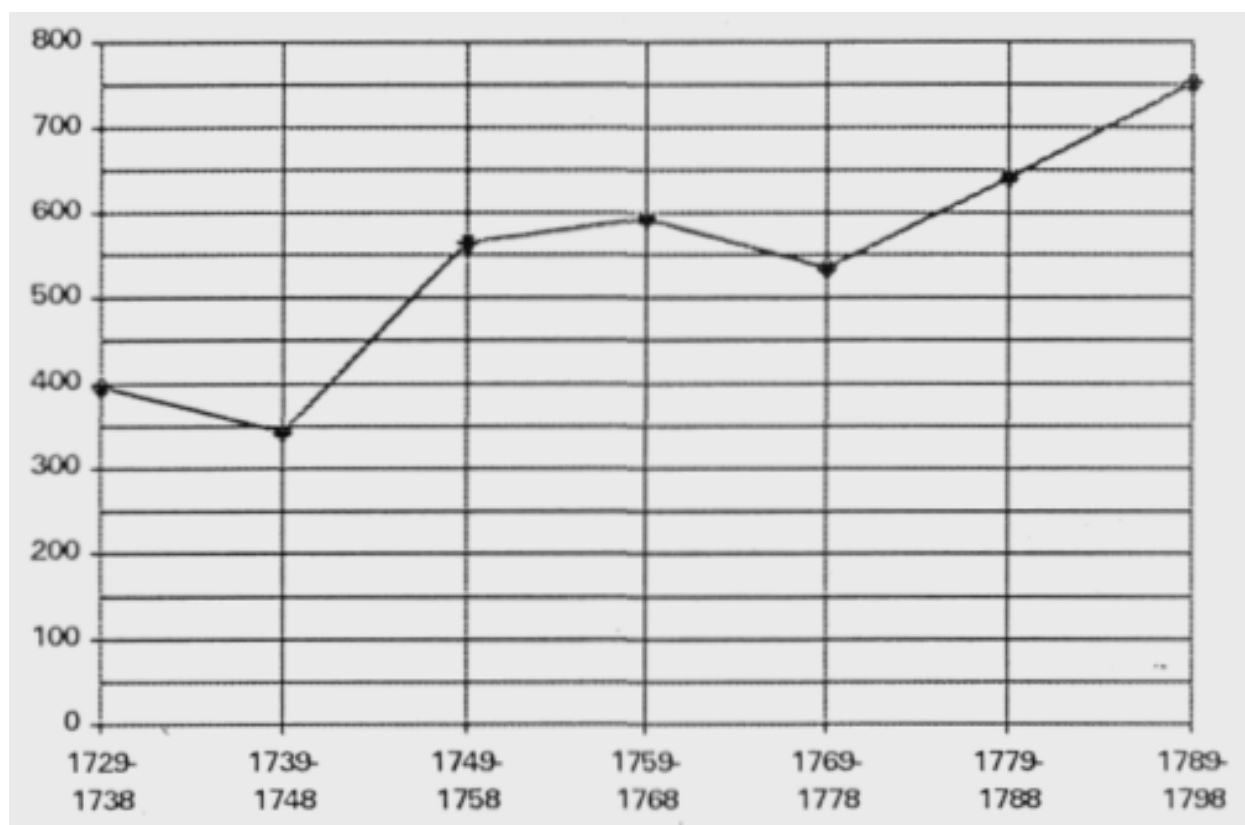

Az 1748 körüli visszaesést kivéve a század második felében is felfelé ívelő tendenciát mutat a születések száma Zetelakán. De ekkor ez a folyamatos növekedés már Havasalja valamennyi falujára jellemző. Így hát számok tükrözte tényként kell elfogadnunk azt, hogy a századelőn, eltérően a tájegység összes többi településétől, Zetelaka növekedett.

Még mindig a tényeknél, azok bemutatásánál maradva, még az értelmezés és summázás előtt szeretnénk beiktatni ide a következő táblázatot, amelyet - bár vizsgált korszakunk időhatárait meghaladja - a teljes kép, a történelmi térben és időben való biztosabb tájékozódás szempontjából fontosnak vélünk.

(V.)

\begin{tabular}{|c|c|c|c|c|c|c|c|c|c|c|c|}
\hline & \multicolumn{2}{|c|}{1721} & \multicolumn{2}{|c|}{1750} & \multicolumn{2}{|c|}{1786} & \multicolumn{2}{|c|}{1857} & \multicolumn{2}{|c|}{1992} \\
\hline & & lélek & $\%$ & lélek & $\%$ & lélek & $\%$ & lélek & $\%$ & lélek & $\%$ \\
\hline 1. & Fenyéd & 215 & 8,36 & 245 & 7,68 & 364 & 7,96 & 509 & 6,46 & 909 & 7,56 \\
\hline 2. & $\begin{array}{l}\text { Máré- } \\
\text { falva }\end{array}$ & 230 & 8,95 & 325 & 10,19 & 479 & 10,48 & 974 & 11,78 & 2017 & 16,79 \\
\hline 3. & $\begin{array}{l}\text { Kemény- } \\
\text { falva }\end{array}$ & 150 & 5,83 & 175 & 5,50 & 222 & 4,85 & 443 & 5,38 & 695 & 5,78 \\
\hline 4. & \begin{tabular}{|l} 
Zete- \\
laka
\end{tabular} & 1030 & 40,08 & 1230 & 38,58 & 1597 & 34,93 & 2659 & 32,16 & 4602 & 38,31 \\
\hline 5. & $\begin{array}{l}\text { Szent- } \\
\text { tamás }\end{array}$ & 60 & 2,33 & 65 & 2,05 & 78 & 1,70 & 120 & 1,45 & 116 & 0,96 \\
\hline 6. & Fancsal & 65 & 2,55 & (93) & 2,91 & 112 & 2,47 & 175 & 2,11 & 146 & 1,21 \\
\hline 7. & $\begin{array}{l}\text { Szent- } \\
\text { király }\end{array}$ & 255 & 9,92 & 270 & 8,48 & 438 & 9,58 & 780 & 9,43 & 1078 & 8,97 \\
\hline 8. & Tibód & 25 & 0,97 & 75 & 2,35 & 130 & 2,84 & 120 & 1,45 & 192 & 1,60 \\
\hline 9. & Ülke & 130 & 5,06 & 165 & 5,17 & 284 & 6,21 & 501 & 6,06 & 424 & 3,55 \\
\hline 10. & $\begin{array}{l}\text { Orosz- } \\
\text { hegy }\end{array}$ & 410 & 15,95 & 545 & 17,09 & 868 & 18,98 & 1986 & 24,02 & 1833 & 15,27 \\
\hline & Össz. & 2570 & 100,00 & 3188 & 100,00 & 4572 & 100,00 & 8267 & 100,00 & 120 & 100,00 \\
\hline
\end{tabular}


Ez a táblázat magába foglalja a 18. századi két legátfogóbb összeírás - az 1750-es adóösszeírás és az 1786-os népszámlálás - Havasalja demográfiájára vonatkozó adatait, nyújt egy 19. század közepi fogódzót, valamint megadja az utolsó 20. század végi népszámlálás még hivatalosan közzé nem tett adatait. ${ }^{54}$ Ami első pillantásra szembetünhet bárkinek, az a települések tájegységen belüli majdnem katonásnak mondható sorrendje ebben a két és fél évszázados, rövidnek nem mondható történelmi időben. Zetelaka mindvégig első, Fenyéd ötödik, Szenttamás tizedik marad, Ülke és Keményfalva felváltva osztozik a hatodik-hetedik helyen, de változás, alapvető változás nem történik. Ez egyrészt a forrásaink viszonylagos megbízhatóságára, másrészt pedig arra enged következtetni, hogy itt egy behatárolt életterü, részben zárt, esetleg hagyományba is merevedett közösségről van szó, olyanról, ahol a kis falu kicsi, a közepes közepes maradt, de megmaradt, sok mindent túlélve és sok mindennek ellenállva a századok folyamán. De ne engedjünk még az értelmezés kényszerének és nézzük meg, mekkora volt falvanként a növekedés és hogy aránylik ez a szék lakosságának növekedéséhez.

Vegyük az utóbbit. Udvarhely-, Keresztúr- és Bardóc-fiúszék településeinek száma 1614 és 1750 között mintegy 129 (nem számítva Udvarhely városát, de beleszámítva Keresztúrfalvát). A szék összlakossága 1614-ben 24 935, Havasaljáé 1980. Havasalja ekkor a széki összlakosság 7,49 százalékát képviselte. 1750-re ez 11,60 százalékra nőtt, lévén ekkor a szék lakossága 27460 , a tájegységé pedig 3188. A szék összlakosságának növekedése 1614-től 1750-ig 10,12 százalék, Havasaljáé 29,79, tehát jóval magasabb, mint a széki átlag. ${ }^{55}$ Ezt a növekedést ebben az időszakban és különösen a 18. század első felében épp a tájegység havasaljai volta, viszonylagos elzártsága tehette lehetővé.

Havasalja lakosságának falvankénti százalékos növekedése a következőképpen alakult a 17-18. század folyamán:

(VI.)

\begin{tabular}{|r|l|c|c|c|}
\hline & & 1614-töl 1721-ig & 1721-töl 1750-ig & 1750-töl 1786-ig \\
\hline 1. & Fenyéd & 22,85 & 13,95 & 48,57 \\
\hline 2. & Máréfalva & $-2,12$ & 41,30 & 47,38 \\
\hline 3. & Küküllökeményfalva & 7,14 & 16,66 & 26,85 \\
\hline 4. & Zetelaka & 160,75 & 19,41 & 29,83 \\
\hline 5. & Szenttamás & 9,09 & 8,33 & 20,00 \\
\hline 6. & Fancsal & $-23,52$ & 43,07 & 20,43 \\
\hline 7. & Szentkirály & $-15,00$ & 5,88 & 62,22 \\
\hline 8. & Tibód & $-73,68$ & 200,00 & 73,33 \\
\hline 9. & Ülke & $-3,70$ & 26,92 & 72,12 \\
\hline 10. & Oroszhegy & 12,32 & 32,92 & 59,26 \\
\hline
\end{tabular}

A mínusszal jelzett számok természetesen csökkenést jelentenek, a századelő katasztrófa sújtotta évtizedeinek következményét jelzik. A legkiemelkedőbb eset, Tibód 200 százalékos növekedése 1721-1750 között az azelötti 73,68 százalékos csökkenés után pedig nem jelez mást, csupán azt, hogy Tibód lakóinak száma 25-ről 75-re emelkedett, mert a ragály, háború, szárazság sújtotta időszak alatt csaknem elpusztult a falu (a conscriptorok 1721-ben és 1722ben is csak öt családföt találtak itt).

\footnotetext{
${ }^{54}$ Vofkori László: Erdély közigazgatási és etnikai földrajza. Vörösberény, 1996. 132-133.

${ }^{55}$ Indokoltnak látszik, hogy a század második felére is elvégezzük ezeket a számításokat, de forrásaink nem teszik lehetővé, az összeírások itt ugyanis úrbéri conscriptiók, a II. József- féle népszámlálás pedig nem követi a régi területi-közigazgatási beosztást.
} 
Mivel egy demográfiai adatsor önmagában nem értelmezhető, egy 200 százalékos növekedésnek ugyanis nincs adott esetben önmagában semmilyen különös, rendhagyó következménye (mint azt az elöbbi példával is igazoltuk), s minthogy forrásaink milyensége és mennyisége ebben a században (nemcsak Havasalja, hanem Erdély számos tájegységének viszonylatában) lehetetlenné teszi a demográfiai kép olyan, a teljesség igényével történő bemutatását, amelyben tényleges, természetes szaporulattal, a népfelesleg különböző válfajaival számolhatnánk, fokozott figyelmet kell szentelnünk a tényezők azon együttesének, amelyek befolyásolják a népesedéstörténetet, a demográfiai mutatókat, és amelyek forrásaink típusainak köszönhetően rendelkezésünkre is állnak. Természetesen a gazdaságra gondolunk itt, elsősorban a mezőgazdaságra, hisz Erdély népessége és ezen belül a Székelyföldé még a 19-20. század fordulóján is túlnyomórészt agrárnépesség. Havasalja lakói az 1785-86-os, valamint az 1819-20-as úrbéri összeírások exameneiben egyhangúlag földművesnek mondják magukat. A népsürüség- és különösen az agrárnépsürüség-számításban különleges jelentősége van a földminőségbeli különbségeknek, a müvelési ágak helyi fontosságának (Csík és Udvarhely vármegye szántója például Erdély leggyengébb minőségü szántóterülete $\left.{ }^{56}\right)$.

\section{c) Föld és ember}

A teljesebb demográfiai kép érdekében vessünk egy pillantást Havasalja társadalmi szerkezetére és az azt meghatározó gazdasági keretre.

Tájegységünk társadalmi megoszlását összefoglaló alábbi táblázatunkról előrebocsátanánk, hogy az 1786-os népszámlálás adatai azért nem szerepelnek benne, mert a népszámlálás csak a jogi és tényleges népesség számát adja, az egyes társadalmi kategóriákat külön nem tünteti fel. A táblázatban szereplő „szabad” lovon és gyalog katonáskodót jelöl. Ezek a conscriptiókban primipilus, pixidarius és libertinus néven szerepelnek. (Az összesítésből Fancsal 1750-es adatai hiányoznak. $)^{57}$

(VII.)

\begin{tabular}{|l|r|r|r|}
\hline & $\mathbf{1 6 1 4}$ & $\mathbf{1 7 2 2}$ & $\mathbf{1 7 5 0}$ \\
\hline Armalista & 1 & 9 & 8 \\
\hline Szabad & 270 & 431 & 471 \\
\hline Jobbágy & 86 & 55 & 75 \\
\hline Zsellér & 39 & 11 & 45 \\
\hline Egyéb & - & 45 & 20 \\
\hline Összesen & $\mathbf{3 9 6}$ & $\mathbf{5 5 1}$ & $\mathbf{6 1 9}$ \\
\hline
\end{tabular}

A havasaljai falvak társadalmi megoszlása is megerősíti azt a következtetést, melyet más tájegységek, a székely székek és az egész Székelyföld vonatkozásában már számszerüen igazoltak a kutatók, nevezetesen, hogy a székely társadalom nem is teljességében nemesi és nem is összességében eljobbágyosodott társadalom. Összetevő komponensei közül legszámosabb a szabad kategória, a primipilusok, pixidariusok, libertinusok rétege, és ez az évszázadok folyamán nem veszít nagyságából és erejéből. Havasalja falvai esetében enyhe növekedést mutat, és arányát más kategóriákhoz (jobbágy, zsellér) viszonyítva akkor is megőrzi, amikor a

\footnotetext{
${ }^{56}$ Venczel József: A székely népfelesleg. Hitel, Kolozsvár, 1942. VII. évf. 1. 20.

${ }^{57}$ Lásd a 16. és 35 . sz. jegyzetet.
} 
vészteljes időkben az összlakosság száma erősen lecsökken. ${ }^{58}$ Ezt a megoszlást illusztrálja az alábbi grafikon is, mégpedig a század egyik legreprezentatívabb esztendejében, 1750-ben, amely nemcsak azért viszonyítási év számunkra, mert a század közepén van, annak mondhatni vízválasztója, nemcsak azért, mert ekkor történt a század legátfogóbb, legnagyobb horderejü összeírása, hanem azért is, mert eddig tartott, eddig elhúzódott az az időszak, amit az első negyedszázad katasztrófái határoztak meg, és amelyet talán a tévedés kockázata nélkül nevezhetünk a regenerálódás idejének.

A 18. század második felének és a 19. század elejének legfontosabb conscriptiói úrbéri összeírások, melyek a szolgáló emberek létszámára, vagyoni állapotukra és urukhoz füződő viszonyukra derítenek fényt. Az 1785-ös úrbéri conscriptio tanúsága szerint Havasalján 144 szolgáló ember volt, 104 jobbágy és 40 zsellér $^{59}$, míg a Conscriptio Czirakyana a tíz faluban 44 jobbágyot és 35 zsellért ír össze. ${ }^{60}$ 1777-ben Zetelaka privilegizált községben 290 libertinust, 26 jobbágyot, 17 zsellért, 1 vagust és 5 cigányt talál a szántók és kaszálók hozamára kíváncsi hatalom. ${ }^{61}$ 1778-ban az Oroszhegy környéki hat faluban, Ülkében, Fancsalban, Tibódon, Szenttamáson és Szentkirályon 10 armalistát, 270 libertinust, 69 jobbágyot és 15 zsellért írnak össze az agrárkapacitást számba vevő conscriptorok. ${ }^{62}$

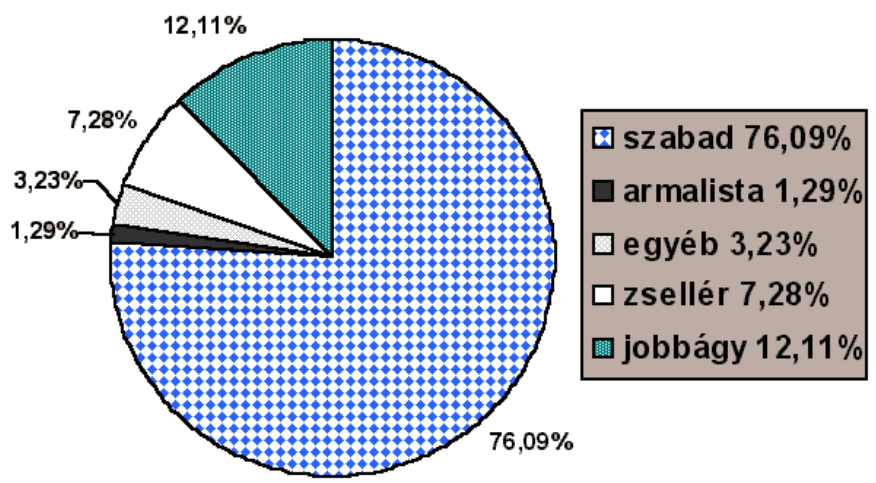

A különböző társadalmi rétegeket nem választotta el merev válaszfal. A falu, amely megkívánta a közösségben való müködést, nem is kedvezett ennek. A társadalmi mozgás több irányú, de a kor dokumentumai leggyakrabban az elszegényedés, a birtokvesztés révén történő státusváltozást jelzik. „Az elmúlt Esztendőben nagyon el szegényedtem, és sokkal meg adosottam, nyomorék feleségem neveletlen gyermekem tarto, nintsen egyebem egy benvalo joszágon rajta lévő Házzal, ell adván szántom zálogára"63 - hangzik zetelaki Orbány Ignátz panasza,

${ }^{58}$ 1713-ban, a ragály és éhínség idején, az Oroszhegyhez tartozó hat faluban az összcsaládfök 63,11 százalékát a szabadok alkották. Természetesen a szabadok nagy részaránya a faluközösségen belül nemcsak a Székelyföldre jellemző. Így volt ez máshol is, hisz hasonló feltételek hasonló életmódhoz vezetnek, mint például Moldva răzeşi falvaiban, valamint a havasalföldi moşneni communitásokban. Vö. Stahl, Henri H.: A régi román falu és öröksége. Bp., 1992. 75-82.

${ }^{59}$ 1785-86-os úrbéri összeírás. MOL. F. 51. 23-24. csomó.

${ }^{60}$ Conscriptio Czirakyana. 1819-1820. MOL. F. 52. 118. kötet.

${ }^{61}$ UszLt. Közigazgatási akták. 1777. évi 88. sz. irattartó.

${ }^{62}$ UszLt. Közigazgatási akták. 1778. évi 91. sz. irattartó.

${ }^{63}$ UszLt. Közigazgatási akták. 1835. évi 570. sz. irattartó. 
kinek a székhez kellett fordulnia azért, hogy a bíró hatalmaskodással meg ne vegye birtokát, az ő szabad jószágát „betsű árán”, „holott találtatott olyan érdemes Uri Ember a ki ád 600 száz [!] forintot zálogára". ${ }^{64}$

A századforduló után az 1809-es év, a nemesi felkelés éve az, amikor általánosan fontossá válik, hogy ki melyik rendhez, milyen társadalmi kategóriához tartozik. „Mü Nemes Udvarhelyszékben Oroszhegyben lakok akik az ide aláb Nevünket subskribálytattyuk Adgyuk az Bizonság tevő Levelünket iljen Dologroll hogy Czincziri András Oroszhegyben ált fel, it lakot mindenkor de mi nem tudgyuk soha a mü idenkben Urat szolgáltak volna" ${ }^{65}$ - bizonyítják négy „Oroszhegyben lako Nemes személyek” ${ }^{\text {"6 }}$. A régi székely szabadságjogok és kiváltságok visszaadásának garanciája nélkül, a már adózó székelység vonakodott felkelni. A szék levéltárában sokasodnak azok a panaszlevelek, melyek valamelyik családtag zászló alá sorolás alóli felmentését kérik, „mint hogy egy fiam vagyon/: a ki lustráltis:/ mustráltis"67 - mondja Fenyédi Sándor Lőrincz, „Mint, hogy az fijam Máréfalvi kissebb Pál István el irattatott gyalog katonának az Insurectióba tehát ez okon ilj méltó mentségemet kéntelenítettem Nagyságod és a Tekintetes Permanens Comisio eleibe feladnom a véget hogy az írt fijam gazdának mellettem meg maradgyon, mint hogy a jobb karom ez elött öszve romlott s törött ugy hogy sem fel emelni jól nem tudom, sem szántani sem vetni, még tsak egy tisztességes létzet is vélle nem tudok vágni” ${ }^{68}$ - panaszolja Máréfalvi Öreg Pál István, kérvén alázatosan a „méltóságos Liber Báró kiráj Bíró Urat” és a „Tekintetes Commisiot”, hogy méltóztassanak ,az írt fijamat mellettem gazdának meg hagyni, mint hogy ezekről recognoscálhat az egész Marefalvi communitás is".

Az ilyen és ehhez hasonló eseményekkel együtt a mindennapokkal való viaskodás nem változtatott számottevően Havasaljának az előbbiekben bemutatott társadalomszerkezetén, és itt hadd idézzük az angol (és európai) tradicionális társadalmak, közösségek egyik kiváló ismerőjét, Peter Laslett-et, aki az Elvesztett világban azt mondja, hogy „forradalom, visszavonhatatlan változás, amely magát a társadalmi szerkezetet változtatja meg [...] majdnem soha nem történhetett meg a tradicionális, patriarchális, iparosodás előtti társadalmakban". ${ }^{69}$

Még figyelmeznünk kell valamire, ami adalék a még pontosabb népesedéstörténeti képhez, és az nem más, mint a következő:

Mekkora területen lakott ez a népesség? Hány telken, mekkora szántón gazdálkodott? Mekkora volt a faluhatár? Megannyi nagyságrendre vonatkozó kérdés, ami elválaszthatatlan a népesedési adatoktól, hisz ezek a gazdasági potenciál függvényei is.

Mivel forrásaink bizonyos időszakokra nem szolgáltatnak adatokat, és főleg a század első felében történő összeírások nem országosak, hanem meglehetősen esetlegesen vesznek számba vidékeket - kérdéseinket röviden megválaszolandó -, ismét csak a Bosnyák és Ballé patakok menti hat falut, Oroszhegyet és környékét vesszük szemügyre. A tájegység Küküllő menti

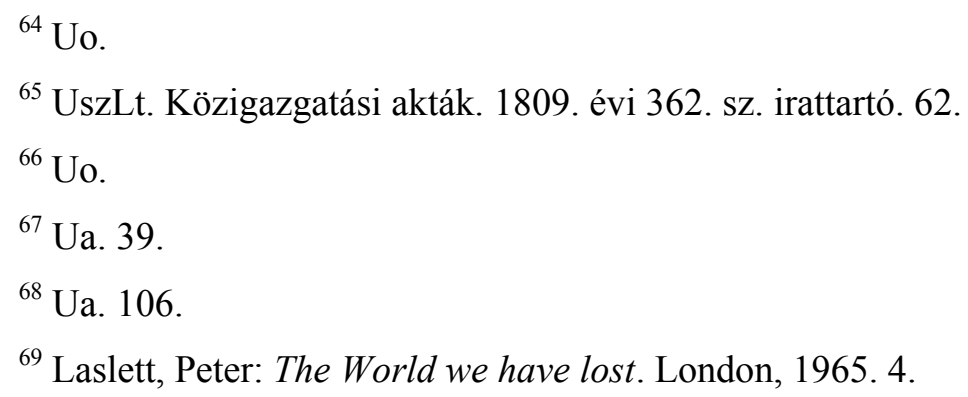


felével, az egész tájegységgel ilyen szempontból részletesen a következő fejezetben foglalkozunk, adataink viszont az egész tájegységre nézve reprezentatívak.

A birtokolt szántóföld és igaerő Oroszhegyen és környékén a 18. században a következöképpen alakult:

(VIII.)

\begin{tabular}{|l|c|c|c|c|}
\hline & \multicolumn{2}{|c|}{ Szántó } & \multicolumn{2}{c|}{ Igaerö } \\
\hline & $\begin{array}{c}\text { Összesen } \\
\text { köböl }\end{array}$ & $\begin{array}{c}\text { Egy családföre eső } \\
\text { köböl }\end{array}$ & $\begin{array}{c}\text { Összesen } \\
\text { ökör + ló }\end{array}$ & $\begin{array}{c}\text { Egy családfóre eső } \\
\text { ökör + ló }\end{array}$ \\
\hline 1713 & 1217 & 10,79 & 306 & 2,50 \\
\hline 1722 & 2543,25 & 12,28 & 506 & 2,44 \\
\hline 1750 & 2718,50 & 12,13 & 477 & 2,12 \\
\hline
\end{tabular}

A conscriptiók tanúsága szerint ez a határ nem tág. Még akkor sem, ha figyelembe vesszük, hogy forrásaink megalkotói adókivetésben gondolkodva vették számba a földbirtokot, melynek során az itt-ott való kedvezés eléggé szokásos gyakorlattá vált, ami aztán szükségszerúen azzal járt együtt, hogy a lajstromokban kissé megfogyatkozott a föld. Ami még fontosabb, hogy ez a határ nem növekszik számottevően. Nem növekedhet, mert az erdő szorításában él, az irtással elhódítható szántó pedig ilyen és ehhez hasonló hegyvidéki körülmények között nem lehet igen nagy terület. Az egy családföre eső szántó (köbölben) mégsem sokkal kisebb, mint a Székelyföld hasonló természeti adottságokkal rendelkező tájegységein. Például 1713-ban Kászonszék négy falujában az egy családföre eső szántó 10,73 köböl, Oroszhegy falvaiban 10,79. Ugyanez 1721-ben ott 13,78, Oroszhegyen 12,28. ${ }^{70}$ Az 1750-es adatok között sincs számottevő nagyságrendbeli különbség, ami arra enged következtetni, hogy a Székelyföld különbözö vidékein egy alapvetően azonos termelési mód létezett és őrződött meg a maga hagyományszerüségében.

A szántóhatár tehát szük, nincs hová terjeszkedni, az igaerő sem sok. Egy családfőre átlagban két, két és fél ökör vagy ló jut. Ezek a körülmények is magyarázzák részben azt a demográfiai tényt, amit az elözőkben már bemutattunk, nevezetesen, hogy a három törpetelepülés: Fancsal, Tibód és Szenttamás lélekszáma két évszázadon át alig változott (75-200 között ingadozott). Olyan lélekszámnövekedést, ami figyelemre méltó, csak a nagy és közepes falvak mutatnak: Zetelaka, Máréfalva, Oroszhegy és a 20. században Szentkirály.

A természetes szaporulat és a tényleges szaporulat közti különbség a népfelesleg. A Székelyföld népfeleslege két részre oszlik: egyik fele gyarapítja a helybeli székelységet, ez az álló népfelesleg, a másik „mozgó elemmé” lesz, elvándorol, ez a mozgó népfelesleg. ${ }^{71}$ Ennek elvándorlása különösen jól nyomon követhető az 1881 utáni évtizedekben, de létezett a 17. és 18. századokban is, ezeket „,méltán nevezhetjük a romlás századainak, amikor általános és bevett szokás, hogy a székek állandóan boldogtalanságukról panaszkodnak" ${ }^{72}$ A mozgó népfelesleg elvándorlását megakadályozandó, a népesedésben beálló feszültségeket enyhítendő és megoldandó a 18. században is születtek rendeletek, melyekben megparancsolták, hogy ahol „Moldvára menő utak és ösvények vadnak, azokra mindenütt szorgalmatos vigyázások legyen minden tisztviselőnek; ha marhástól, feleségestől innet Erdélyből az szegénység által akarna

\footnotetext{
${ }^{70}$ Imreh István-Pataki József: Kászonszéki krónika 1650-1750. Bp., L. 1992. 117,

${ }^{71}$ Venczel József: i.m. 25-28.

${ }^{72}$ Uo. 31.
} 
menni, el ne bocsássák, hanem megtartóztassák..."73 Csakhogy guberniumi rendelettel nem lehetett megállítani ezt a folyamatot. Akkor sem, később sem. Ha táblázatainkat (különösen a VI. táblázatot) szemléljük, ahol azt láthatjuk, hogy pl. Fenyéd lakossága 1750-töl 1786-ig 48,57 százalékkal nőtt, arra kell gondolnunk, hogy ez a növekedés nem más, mint ez alatt az idő alatt képződött népfelesleg. Azt mondhatjuk erről a növekedésről, hogy már jelentős, de természetesen mindig valamihez viszonyítva, példánk esetében az 1721-es állapotokhoz mérve.

Havasaljával kapcsolatos demográfiai vizsgálódásaink során találkoztunk egy olyan jelenséggel, amellyel a későbbiekben részletesebben foglalkozunk majd, és amelyre a néprajzkutatók is felfigyeltek. A mozgó népfelesleget, esetenként az álló népfelesleg egy részét, bizonyos falvak úgy vezetik le, hogy a havasi, eredetileg csak nyári szállásaikból kirajzással új településeket hoznak létre. A folyamat nyilván nem 18. századi, hanem későbbi. Az új, hegyi települések közül némelyek a 19. század fordulója után, a 20. század elején képesek teljes önállósulásra is, községgé válnak, mint például az oroszhegyiek szállásokra való „feltelepedéséböl” alakult Varság.

Összefoglalva az eddigieket, Havasaljáról a következőket mondhatjuk:

A 18. század folyamán és a 19. század elején (különösen a 18. század második felében) a tájegység lakossága gyarapodott, de robbanásszerü változás nem történt itt. Falvai szervesen illeszkednek Udvarhelyszék kishelységekből álló településhálózatába. Havasalja hagyományőrző közösségnek az élettere. Nehezen éri el a változás, és nehezen ad teret a változásnak. (A változás szempontjából gyors és pozitív eredményt a társadalom strukturális átépítése, az agrár életforma felszámolása hozhatna.) Fejlődése úgy sajátos, ahogy az egész Székelyföldé az.

\footnotetext{
${ }^{73}$ Uo.
} 


\section{A havasaljai falvak társadalmi és gazdasági helyzete \\ a 17-18. században}

\section{a) Társadalmi szerkezet}

Jóllehet olyannyira sajátos, még sincs kizárólagosan székely sors, rokonítható az sok más népcsoport adott időszakbeli, azonos okok nyomán kialakuló életútjával.

Az előbbiekben részben már bemutatott tájegység, az udvarhelyszéki Havasalja, ez a több falut magába foglaló formáció, amely gazdasági, társadalmi egységként, életkeretként müködik egy kisközösség számára, szintén nem kizárólagosan székely sajátosság. Európában és itt a Kárpátmedencében sem rokontalan. Jelen esetben mégsem a rokonságra, a rokoníthatóságra figyelmezünk (azt csak jelezni szeretnénk), hanem a sajátosságokra, Havasaljának mint a székelységen belül is sajátos szerepet betöltő tájegységnek a specifikumaira.

Vizsgálódásaink többfókuszúak: a társadalmi rétegződés, majd a gazdaság fejlődésének sajátos menetét szeretnők megvilágítani, és mivel a társadalom elválaszthatatlan az intézményeitől, fényt szeretnénk deríteni ezen intézmények - elsősorban a faluközösség - mechanizmusaira, melyek a közösségi létet a maga egészében - általános és sajátos elemeivel együtt müködtetik. Két kérdéscsoport köré tömörítenénk mondanivalónkat:

a) Társadalomtörténeti vonatkozásban: mivel magyarázható Havasalján a szabadrendủek dominációja? Miért nem a szolgáló emberek, a colonusok, inquilinusok, subinquilinusok száma nő? Kinek a jobbágya a jobbágy?

b) Milyen volt a viszony a tájegységen belül a különböző társadalmi rétegek között? Milyen itt az egyes rétegek gazdasági súlya, fontossága? Milyenek a mindennapok, a gazdálkodás, az emberközi viszonyok? Van-e ellentét, társadalmi feszültség?

A két kérdéskörre adandó válaszok kirajzolják Havasaljának mint tipikusan hegyvidéki székely tájegységnek a sajátosságait a gazdasági, társadalmi, demográfiai és intézményes élet mechanizmusával együtt. Ezt a képet a történeti valóság ezen felsorolt komponenseire nézve modellértékünek tekinthetjük.

Tekintsük át mindenekelött - most már nem kimondottan a népesedés történetére figyelmezve Havasalja társadalmi rétegződését, amelyet a következő táblázatban összesítünk. ${ }^{74}$

(IX.)

\begin{tabular}{|l|r|r|r|}
\hline & \multicolumn{1}{|c|}{$\mathbf{1 6 1 4}$} & \multicolumn{1}{|c|}{$\mathbf{1 7 2 2}$} & \multicolumn{1}{|c|}{$\mathbf{1 7 5 0}$} \\
\hline Armalista & 1 & 9 & 8 \\
\hline Primipilus & 100 & 177 & - \\
\hline Libertinus & 170 & 254 & 471 \\
\hline Jobbágy & 86 & 55 & 75 \\
\hline Zsellér & 39 & 11 & 12 \\
\hline Ház nélküli zsellér & - & - & 33 \\
\hline Kóborló & - & 37 & 13 \\
\hline Egyéb & - & 8 & 7 \\
\hline Összesen & $\mathbf{3 9 6}$ & $\mathbf{5 5 1}$ & $\mathbf{6 1 9}$ \\
\hline
\end{tabular}

${ }^{74}$ A számok családföket jelölnek. A táblázatban a pixidariusok kategóriáját a libertinusokkal együtt tüntettük fel. (Az adatokra vonatkozóan lásd a bevezetés 8. sz. jegyzetét.) 
(Zárójelben szeretnénk ismételten megjegyezni, hogy használt forrásaink, a különböző típusú conscriptiók sem mentesek - mint általában az írott történelmi források - a bizonytalanságtól, következetlenségtől, sokszor nehéz követni a tollforgató, a scriba „,szubjektív” szemléletmódját, ennek ellenére hosszabb időszak - félévszázad, évszázad - bővebb adatsorai biztosabb támpontokat, trendeket kínálnak, és lehetővé teszik, hogy a megoszlásokat, arányokat pontosabban mérhessük fel.)

Havasalján a Bethlen Gábor országlásától számított másfél évszázadban állandósult, majd megnövekedett a szabad családfök száma. 1750-ben az armalista, primipilus, pixidarius és libertinus családfők az összcsaládfők 77,85 százalékát teszik ki. Ez a lófó és gyalog székely többség a 18. század közepén nagyobb a székelyföldi átlagnál, és nagyobb például a kászonszéki átlagnál is, ami a maga 67,38 százalékával a Székelyföld egészében szintén kiemelkedően magas arány. ${ }^{75}$ Ezen a vegyes jogállású székelységen belül, ahol jobbágyok és zsellérek szabadrendiekkel együtt élnek, az alávetettek, a szolgáló emberek létszáma - forrásaink tanúsága szerint - állandósult. 1614-ben 125 szolgáló ember van Havasalján, ez a szám 1722-re a századelő katasztrófáinak betudhatóan 66-ra csökken, de 1750-re ismét a stabilitást tükröző 120-as számmal jegyzi a nagy országos adóösszeírás a tíz falu jobbágyainak, inquilinusainak és subinquilinusainak számát. A szolgáló emberek számbeli, gazdasági súlyáról, a faluközösségben elfoglalt helyükről, szerepéről sokat árulnak el a 18. század második felének és a 19. század elejének úrbéri összeírásai, a már többször említett, idézett 1785-ös úrbéri összeírás és a Conscriptio Czirakyana. Bár ezek csak a szolgáló népességre vonatkozóan szolgáltatnak adatokat, az adóösszeírásokkal való együttes használatuk - mivel adataik kiegészítik egymást közelebb visz a történeti valóság megismeréséhez.

„Határunk kettő vagyon, mellyeknek edgyüttvéve a negyedik része a tiszta és elegyes búzát, úgy a rosot jól meg trágyázva meg termi, a többi részein a Soványság, kövek, kősziklák és haszontalan hegyek miatt meg nem teremnek" - felelik az 1785-ös úrbéri összeírás examenjének negyedik pontjára az Oroszhegyen felesketettek. ${ }^{76}$ A szántóhatár bevallások szerinti leírása azonos képet nyújt a 18. század elején, második felében és a 19. század első negyedének végén is Havasalja valamennyi falvában. 1722-ben a conscriptor Szenttamásról, a tájegység legkisebb communitásáról szintén a következőket írja: „Egy zárt völgyben fekszik, csekély hasznú és szárazság idején gyakran elapadó patak mellett. Két részre osztott határa van, részben déli, részben északi fekvésü; váltóforgóban négy ökörrel szoktak szántani, a szükséges trágyázással őszi és tavaszi vetésre közepes termésre alkalmas." "77 Ha fokozottan figyelembe vesszük a források hibalehetőségeit, azt, hogy az úrbéri összeírások kérdéseire adott feleletek is szabványosítottak, nem mentesek az öket papírra vető írástudó kordivatnak megfelelő kincstári nyelvi fordulataitól, valamint azt, hogy a parasztoknak nem állt érdekében pontosan bevallani az általuk bírt teljes földmennyiséget, még akkor is a megélhetést nyújtó határ képe megbízhatóan kirajzolódik ezekből a forrásokból. „,...agyagos határunkat két fordulloban használljuk, s inkább négy ökörrel mint kettővel mivelhettjük" - vallják az investigatoroknak a szentkirályiak 1820. július 29 -én. ${ }^{78}$ A határ köves, agyagos, nehezen mívelhető, egészében véve szük, kevés, és minden egyes falunál, mindkét úrbéri összeírás alkalmával

\footnotetext{
${ }^{75}$ Imreh István - Pataki József: Kászonszéki krónika. 42.

${ }^{76}$ 1785-86-os úrbéri összeírás. MOL. F. 51. 23. csomó. 4.

${ }^{77}$ 1722. évi összeírások. Vegyes conscriptiók. MOL. F. 49. 12. csomó. 7. tétel. 89-90.

${ }^{78}$ Conscriptio Czirakyana. 1819-1820. MOL. F. 52. 118. kötet. 194.
} 
elhangzik - 1820-ban tételesen, azonos szavakkal megfogalmazva, ugyanabba a formulába öntve -, hogy ,a Határnak felit közepes Joságunak, a más felit alább valónak lehet venni”. ${ }^{79}$ A határ terméketlenségét, azt, hogy falunként felibe vagy negyedibe ha megterem a búza, rozs, haricska, és az is csak jó trágyázással, a havasaljai körülmények okozzák. Közel a havas. Szorításában ilyenné vált a gabonatermesztés, és ilyen is maradt. Irtással lehetne meg- és visszahódítani területet, szántót a falu számára, de 1785-ben egyáltalán nem, 1820-ben pedig összesen három faluban írtak össze irtásföldet. ${ }^{80}$

Ez a határ földrajzi adottságainak következtében csak egy bizonyos lélekszámot tudott eltartani. Havasalja nem az a hely, amely alkalmas lett volna nagy jobbágytelepítésekre. A természetes szaporulatnak köszönhetően így is aprózódik a telek, a szabadrendüeké és jobbágyoké egyaránt, ezért olyan gyakoriak a conscriptiókban az 1/4, 1/8, 1/12-ed nagyságrendű belső telkek (amelyekről így sem tudjuk egészen pontosan megmondani, hogy mekkorák, hisz a Székelyföldön és így Havasalján sem volt egy szabványosított, törvény szentesítette teleknagyság, amelyhez valamennyi telek mérhető lett volna). Természetesen nemcsak a telek aprózódik, hanem a hozzá tartozó külső appertinentia is.

A határ terméketlensége mellett más is útját állta, kedvét szegte a Havasaljára való olyan méretű jobbágytelepítésnek, ami változtathatott volna a társadalmi struktúrán. A földközösségként is müködő faluközösségben a közhatárból való részesedés kulcsszerepe, amint az Approbatae Constitutiones is kimondja, ${ }^{81}$ már a 17. századtól kezdve az antiqua sessióra van kiosztva. Aki nem rendelkezett antiqua sessióval (vagy másképp mondva belsőséggel, üléshellyel, régi telekkel, ős házhellyel, intravillanummal, nyilas házhellyel és még folytathatnánk a sort), azt nem illette rész a közhatárból, nem jussolt nyilat. Dósa Elek 1861-ben megjelent nagy összefoglaló jogtudományi munkájában az Approbatae Constitutionesre hivatkozva értekezik a régi telkekről, megállapítva, hogy a közhatár használata ,a belső régi telkek birtokarányában illeti azok tulajdonosait". ${ }^{82} \mathrm{Az}$ antiqua sessio olyan rendelkezési arányosságnak a rögzítője, amelyet csak a közösség egésze, Havasalja falvai esetében pedig az elegyes lakosságú faluközösség módosíthat. Közhatárból foglalt, falu földjéből felfogott, irtott belsőséget például nem lehet régi telekszámba venni, sem pedig egy egész telket földarabolással szaporítani. Szokásból lett törvényerejü feltétel az is, hogy a belsőséget „hatvan esztendőktől fogva egyformán antiqua sessiónak" tekintsék. ${ }^{83}$ A commune terrenum, a közhatár fogalomköre tág. Szántó, szénarét, erdő, minden ide tartozott, ami véglegesen felosztva nem volt, minden a régi telkek appertinentiájának, járultságának volt tekinthető. Általában az ,,antiqua” lesz később a kulcs, a részesedési arány meghatározója az egyénivé váló mezőgazdasági területekhez a végleges felosztásnál.

Havasalján így hát amellett, hogy a mostoha természeti feltételek nem vonzották a székely vagy vármegyei nagybirtokosokat, a többségében szabadrendű birtokosok vigyáztak arra, hogy belső telket senki ne idegeníthessen el, s így új colonusokat senki ne telepíthessen a falu által

\footnotetext{
${ }^{79}$ Ua. 455.

${ }^{80}$ Ua. $125-455$.

${ }^{81}$ 1540-1848. évi erdélyi törvények. Corpus Juris Hungarici. Bp. 1900. 101-102.

${ }^{82}$ Dósa Elek: Erdélyhoni jogtudomány. Kolozsvár, 1861. II. 196-197.

${ }^{83}$ Kilyéni Székely Mihály: A Nemes Székely Nemzetnek Constitutiója, Privilégiumai és a Jószág leszállását tárgyazó némelly törvényes itéletei, több hiteles Leveles-tárakból egybe-szedve. Buda, 1818. 257.
} 
elismert intravillanumra. Ezért vallják 1820-ban egyhangúlag a parasztok, hogy „a telkek eladása nemcsak hogy nem szabad, sőt meg is van tiltva". ${ }^{84}$

Bár a két úrbéri összeírás a tájegység valamennyi jobbágyát ősjobbágyként tünteti fel, többségükben nem telepített jobbágyságról van szó, hanem olyanokról, akik az idő folyamán elszegényedés, földzálogosítás okán jutottak szabadsorból függőségbe. Ez a függőségbe jutás $\mathrm{s}$ az elszegényedési folyamat nem erősödik tovább a 18. században s a 19. század első negyedében. A conscriptiók arról tanúskodnak, hogy a szabadrendüek megtartották gazdasági erejüket, társadalmi befolyásukat.

Ahhoz, hogy árnyaltabb legyen a kép, nézzük meg közelebbröl földesúr és szolgáló ember viszonyát.

A földesurak és szolgáló emberek száma Havasalján 1785-ben és 1820-ban községenként a következőképpen alakul. ${ }^{85}$

(X.)

\begin{tabular}{|c|l|c|c|c|c|c|c|c|c|}
\hline \multicolumn{2}{|c|}{} & \multicolumn{4}{|c|}{$\mathbf{1 7 8 5}$} & \multicolumn{4}{c|}{1820} \\
\cline { 2 - 10 } & Földesúr & Jobbágy & Zsellér & Összesen & Földesúr & Jobbágy Zsellér & Összesen \\
\hline 1. & Fenyéd & 7 & 22 & 6 & 28 & 9 & 7 & 10 & 17 \\
\hline 2. & Máréfalva & 12 & 9 & 8 & 17 & 7 & 10 & 3 & 13 \\
\hline 3. & $\begin{array}{l}\text { K. Kemény- } \\
\text { falva }\end{array}$ & 2 & 3 & - & 3 & 3 & 1 & - & 1 \\
\hline 4. & Zetelaka & 9 & 17 & 22 & 39 & 12 & 3 & 8 & 11 \\
\hline 5. & Szenttamás & 2 & 1 & 1 & 2 & - & - & - & - \\
\hline 6. & Fancsal & $*$ & $*$ & $*$ & $*$ & - & - & - & - \\
\hline 7. & Szent-király & 10 & 21 & - & 21 & 9 & 12 & 1 & 13 \\
\hline 8. & Tibód & 5 & 10 & 1 & 11 & 7 & 5 & 10 & 15 \\
\hline 9. & Ülke & 3 & 3 & 1 & 4 & 3 & 2 & 1 & 3 \\
\hline 10. & Orosz-hegy & 5 & 18 & 1 & 19 & 6 & 4 & 2 & 6 \\
\hline & Összesen & $\mathbf{5 5}$ & 104 & $\mathbf{4 0}$ & $\mathbf{1 4 4}$ & $\mathbf{5 6}$ & $\mathbf{4 4}$ & $\mathbf{3 5}$ & $\mathbf{7 9}$ \\
\hline
\end{tabular}

Táblázatunkból látható, hogy 45 év viszonylatában a birtokos nemesek száma valójában nem változik. 1785-ben a tíz faluban 55, 1820-ban 56 (szolgáló emberrel bíró) nemes volt. A birtokosok számának falunkénti változása sem számottevő, legfennebb eggyel-kettővel nő vagy csökken, hisz összegük is csak így lehet állandó. 1785-töl 1820-ig két falu, Fancsal és Szenttamás teljesen szabadok lakta településsé vált a két úrbéri összeírás tanúsága szerint. Fancsal az 1785-ös összeírásból hiányzik, így reá vonatkozólag nincs összehasonlítási alapunk, Szenttamáson viszont 1785-ben is csak két földesúr, birtokos nemes volt, Tekintetes Kadicsfalvi Török Pál úr és Tekintetes Szombatfalvi János úr, az előbbinek lévén egy féltelkes és házas, külső tartozékok nélküli örökös jobbágya, az utóbbinak pedig egy ház nélküli, másoknál lakó örökös jobbágy-zsellér cigánya. Külső appertinentiával, szántóval, kaszálóval egyik szolgáló ember sem rendelkezett, Török Pál uram jobbágyának féltelke is összesen 726 négyszögöl, azaz 0,45 kataszteri hold volt. Ennek a két vagyontalan jobbágy-zsellérnek vész nyoma a conscriptiók lapjain, de ez a két falu, Fancsal és Szenttamás tájegységbeli súlyán mit sem változtat, továbbra is Havasalja két legkisebb falujaként tarthatjuk őket számon,

\footnotetext{
${ }^{84}$ Conscriptio Czirakyana. 1819-1820. MOL. F. 52. 118. kötet, 130, 167, 198, 231, 279, 342, 416, 454.

${ }^{85}$ 1785-86-os úrbéri összeírás. MOL. F. 51. 23-24. csomó. (Fancsal hiányzik ebböl a conscriptióból. ); Conscriptio Czirakyana. 1819-1820. MOL. F. 52. 118. kötet. 125-455.
} 
legfennebb annyival egészítve ki ezt, hogy a 18. század végére, a 19. század elejére lakossági összetételüket tekintve homogénné váltak.

A két szenttamási jobbágytartó neve is sejteni engedi már, hogy a tájegység földesurainak többsége bebíró földesúr (extraneus): nem laknak a faluban, de birtokot, jobbágyot bírnak ott. Az egyik legnagyobb földbirtokosnak számít a környéken a Kadicsfalvi Török család, ennek is különösképpen az egyik tagja, Kadicsfalvi Török Pál, akinek például 1785-ben Oroszhegyen, Szentkirályon, Ülkében, Tibódon, Szenttamáson és Zetelakán egyaránt vannak birtokai, és a felsorolt falvakban összesen 32 szolgáló emberrel bír. ${ }^{86}$ A 32 szolgáló ember Havasalja viszonylatában nagy számnak tünik, de a tájegység sajátosságait aláhúzandó meg kell jegyeznünk, hogy az alávetettek nagy száma nem jelentett egyúttal nagy földbirtokot is. Kadicsfalvi Török Pál Zetelakán 13 szolgáló emberrel bírt (5 ösjobbággyal, 3 inquilinussal és 5 subinquilinussal), de ennek a 13 embernek nem volt a faluban egyetlen négyszögölnyi intravillanuma és szántója sem, mindössze 2 hold szénarétet mondhattak magukénak, pontosabban ennyi volt uruké birtokjog szerint és az övék használati jog szerint. ${ }^{87}$ „Mi Török Pál ur Jobbágyai Molnár György még legény lévén semmit nem szolgálok, én Molnár János pedig széna tsinálással és faragással mint egy két hetet szolgálok egy Esztendőbe mit hogy más Házába lakom Házbért Benedek Ferentznének fizetek három Mforintot. Mi fen írt ur Czigány Jobbágyi pedig aratással szolgálánk, míg abba tart, szénában is dolgozunk egy két nap, az után Esztendeig semmit sem"88 - vallják a szolgáló emberek a conscriptornak. Ez a zetelaki példa is rávilágít Havasaljának arra a sajátosságára, hogy a Székelyföldön belül is mint tipikusan hegyvidéki tájegység, alkalmatlanabb földesúri földszerzésre (a székely nagybirtok tetemes része nem az ilyen és ehhez hasonló tájegységben található), valamint a székely jobbágy szolgáltatásainak tartósságára, ami nem urbárium, nem egyezményesített kontraktus szerint történt, hanem a hely sajátosságainak, a földesúr kívánalmainak megfelelően, esetről esetre változva.

A kadicsfalvi, szombatfalvi, malomfalvi, bikafalvi, más szóval a környező falvak bebíró birtokosai mellett kerülnek ki a tájegység szülöttei közül is a szomszéd faluban földet bírók: Fancsalról, Fenyédröl, Szentmihályról, Tibódból. 1785-ben nemes Fancsali Sebestyén Ferenc úr 2140 négyszögölnyi (1,33 kataszteri hold) intravillanumot bír Szentkirályon, ami három jobbágya között oszlik meg, a hozzá tartozó külső appertinentiákkal, szántóval, kaszálóval együtt. Tibódi Dakó József úr pedig egy 2484 négyszögöles (1,5 kataszteri hold) appertinentiás belső telek birtokosa saját falujában, Tibódban, melyen két ősjobbágya van. Ez utóbbi példa azonban a ritkább. Többségben a bebíró birtokosok vannak. A rendelkezésünkre álló adatok alapján megállapíthatjuk, hogy a földesurak többsége az Udvarhely környéki falvakból kerül ki, melyekhez hozzáadódnak a tájegység falvainak tehetősebbjei. Társadalmi hovatartozásukat tekintve tehetősebb primipilusok, legtöbbjüket tekintetesként (spectabili) jegyzik a források. Nagy úr, székely föember, grófi címet viselö illustrissimi comitisként jelzett possessor alig jelenik meg a két úrbéri összeírásban, és jelenlétük sem jelenti feltétlenül azt, hogy abban a faluban megnövekedett a jobbágytelkek és tartozékaik, illetve a jobbágyok

\footnotetext{
${ }^{86}$ 1785-86-os összeírás. MOL. F. 51. 23-24. csomó. L. még Jakab-Szádeczky: Udvarhely vármegye története a legrégibb idöktöl 1849-ig. 528-529. Szerintük Török Pálnak Udvarhelyszéken 1778-ban összesen $28+3$ jobbágya van.

${ }^{87}$ Ua. 24. csomó.

${ }^{88}$ Uo.
} 
száma. 1820-ban például Ülkében gróf Toldalagi László birtoka mindössze egy 2 1/4 „bécsi mérő férejü" puszta telek, melyhez három kataszteri hold szántó is tartozik. ${ }^{89}$

Havasalja példája is igazolja azt a Székelyföld vonatkozásában már elfogadott történelmi tényt, hogy a jobbágytartásnak a vármegyékben és különösen az alföldi megyékben fellelhető módja itt ismeretlen. Nincsenek nagy latifundiumok, nincsenek nagy, több száz, több ezer holdat számláló allodiális földek, a székely nagybirtok felaprózott, és szétszórtan terül el a Székelyföld egész területén. ${ }^{90} \mathrm{Ez}$ a birtokforma nem kedvez a nagy jobbágyfalvak kialakulásának, és különösen nem kedvez a jobbágyok létszámbeli gyarapodásának olyan hegyvidéki tájegységek esetében, mint Havasalja, ahol a határ is szük, növelésének módozatai pedig - a közeli havasnak köszönhetően - gyorsan kimeríthetőek.

Miután az első kérdéskörre - arra, hogy miért marad meg a szabadrendủek dominációja itt, miért nem a szolgáló emberek száma nő, kinek a jobbágya a jobbágy - válaszoltunk, és ismertettük Havasalja társadalmi struktúrájának specifikumait, mindazt, amitől Havasalja a székely hegyvidéki tájegység modellje lehet, foglaljuk össze még egyszer számszerüségekbe a tényeket.

A szolgáló emberek száma Havasalján két évszázad alatt így alakul ${ }^{91}$ :

(XI.)

\begin{tabular}{|r|l|r|r|r|r|r|}
\hline & Szolgáló emberek & $\mathbf{1 6 1 4}$ & $\mathbf{1 7 2 2}$ & $\mathbf{1 7 5 0}$ & $\mathbf{1 7 8 5}$ & $\mathbf{1 8 2 0}$ \\
\hline 1. & Jobbágy & 86 & 55 & 75 & 104 & 44 \\
\hline 2. & Zsellér & 39 & 11 & 12 & 15 & 24 \\
\hline 3. & Ház nélküli zsellér & - & - & 33 & 25 & 11 \\
\hline & Összesen & $\mathbf{1 2 5}$ & $\mathbf{6 6}$ & $\mathbf{1 2 0}$ & $\mathbf{1 4 4}$ & $\mathbf{7 9}$ \\
\hline
\end{tabular}

Az egy földesúrra eső jobbágy-zsellérek száma pedig ${ }^{92}$ :

(XII.)

\begin{tabular}{|c|c|c|c|}
\hline & & \multicolumn{2}{|c|}{ Egy földesúrra eső jobbágy-zsellérek száma } \\
\hline & & $\mathbf{1 7 8 5}$ & 1820 \\
\hline & Fenyéd & 4,00 & 1,88 \\
\hline & Máréfalva & 1,41 & 1,85 \\
\hline & Küküllőkeményfalva & 1,50 & 0,33 \\
\hline & Zetelaka & 4,33 & 0,91 \\
\hline & Szenttamás & 1,00 & - \\
\hline & Fancsal & $*$ & - \\
\hline & Szentkirály & 2,10 & 1,44 \\
\hline & Tibód & 2,20 & 2,14 \\
\hline & Ülke & 1,33 & 1,00 \\
\hline & Oroszhegy & 3,80 & 1,00 \\
\hline & Átlagosan a tájegységben & 2,61 & 1,41 \\
\hline
\end{tabular}

\footnotetext{
${ }^{89}$ Conscriptio Czirakyana. 1819-1820. MOL. F. 52. 118. kötet. 449-455.

${ }^{90}$ Imreh István: Erdélyi hétköznapok. Buk., 1979. 45-55.

${ }^{91}$ Az adatok forrásaira vonatkozóan lásd a bevezetés 8. sz. jegyzetét.

${ }^{92}$ Az adatok forrásai: a már többször idézett 1785-86-os úrbéri összeírás és a Conscriptio Czirakyana. (Az 1785-86-os conscriptióból Fancsal - amint jeleztük - hiányzik.)
} 
A több mint két évszázad alatt nem növekszik számottevően, sőt a 19. század elején megfogyatkozik a szolgáló emberek száma. Havasalja társadalmának kevesebb mint egynegyede minősíthető feudális alávetettségben élőnek. A hasonló földrajzi és gazdasági adottságokkal rendelkező Kászonszékkel összevetve megállapíthatjuk, hogy Havasalján a 18. században több a szabadrendü. 1721-ben Kászonszéken az összlakosság 26,39 százaléka él alávetettségben, Havasalján 1722-ben csak 11,97 százaléka; Kászonban az 1750-es adóösszeírás tanúsága szerint a lakosság 20 százaléka szolgáló ember. Havasalján ugyanebben az évben ez 19,38 százalék. ${ }^{93}$ Az egy földesúrra eső jobbágy-zsellérek száma a 18. század végén és a 19. század elején itt átlagosan 1 és 3 között mozog. Sok faluban nem éri el a kettőt, de van, ahol még az egyet sem. Havasalja falvairól tehát azt mondhatjuk, szabad székelyek falvai ezek. Vegyes jogrendủ a lakosságuk, de az alapszínt ez a tájegység gazdaságilag és társadalmilag egyaránt a primipilusoktól, pixidariusoktól, libertinusoktól kapja.

\section{b) Havasalja falvainak gazdasága}

Miután a statisztikai adatok segítségével szólottunk társadalmi szerkezetről, rendi megoszlásról, ennek a megoszlásnak a miértjéről és arról is, hogy kinek a jobbágya a jobbágy, közelítsük meg ezt a szerkezetet a gazdasági fejlődés nézőpontjából, mert ez az, ami tovább tudja árnyalni az egyes rétegek egymáshoz való viszonyát, amit elsődlegesen azért az határozott meg, hogy itt - ki gazdag, ki szegény.

Paraszti, hagyományos életmódról, faluközösségről lévén szó, ami gazdagította ezt a közösséget, az a föld és az erdő volt. Vessünk egy pillantást az elöbbire.

Az összeírások, ha nem is egységesen, de különösen figyelmezve tüntetik fel a vetésterületet, a szántót, de mivel elsősorban az adóügyre összpontosítanak, soha nem jelzik, hogy az egész müvelés alá fogható földvagyonról van-e szó, vagy csupán az abban az évben bevetett parcellákról. Korabeli utalásokra támaszkodva, valamint Trócsányi Zsolt és Domokos Pál Péter megállapításaiból kiindulva, a szántóhatár egészeként értékeltük a mezőgazdaságilag hasznosítottnak és adóalapnak vett területet. ${ }^{94}$ Havasalja szántóinak milyenségéről már szólottunk. „Vagyon két fordullo Határunk köves oldalas Helljeken fekvő és tsak négy ökörrel mivelhetö $\mathrm{s}$ a legjobb mivelés utánis a Határunknak egy harmad résziben ha vetünk egy véka ősz gabonát" - vallják 1820 júniusában Oroszhegyen a béesketettek a conscriptoroknak. ${ }^{95} \mathrm{~A}$ tájegység valamennyi falujában ilyen a határ, ha nem köves, akkor agyagos, keveset ad, és nem túlzás a két úrbéri összeíráskor $(1785,1820)$ egybehangzóan elmondott és akként is megfogalmazott vélemény, hogy egyharmad része ha közepes, a többi annál rosszabbnak mondható. Ez a határ a kor szóhasználata szerint kétnyomásos, azaz két fordulóban művelik. A Habsburgok regnálása alatt megsokasodnak a hármashatár bevezetésére, a föld gazdaságosabb kihasználására irányuló rendeletek. A tájegység sovány földdel rendelkező falvai - ahol állattartás nélkül a földmüvelés nem tudta biztosítani a megélhetést - tiltakoznak. Nem akarják csökkenteni a legelőt, a nyomáshatárt, hisz a rideg és félrideg állattartásnak részben ez az egyik alapja. „Fenyédi Geréb Ferentz, János és több Fenyédiek Protestációja az hármas Határ

\footnotetext{
${ }^{93}$ Imreh-Pataki: Kászonszéki krónika. 41-91.

${ }^{94}$ Trócsányi Zsolt: Az Északi Partium 1820-ban. A Conscriptio Czirakyana adatai. Bp., 1966. 24-94; Domokos Pál Péter: Háromszék és Csiksszék adóösszeirása. 1703. Agrártörténeti Szemle, 1977. 3-4. szám. 440-441.

${ }^{95}$ Conscriptio Czirakyana. 1819-1820. MOL. F. 52. 118. kötet. 412.
} 
felállítása iránt” már 1707-ben megtörténik. ${ }^{96}$ A felvilágosult abszolutizmus évtizedei alatt a faluközösségi autonómiát korlátozó hatalom már büntetés terhe alatt követeli: „Sok Rendben Kegyelmeteknek közönséges Circularisunkkal értésére adtuk az három Határoknak fel állása iránt jött Felséges királlyi, és Méltóságos Királlyi Gubernium többszöri kemény parantsolásait, meg parantsolván kegyelmeteknek hogy az határokot három édgyenlő részekre osztván az három határokat fel állítsák múlhatatlanul. De mégis találtatnak ollyan faluk, kik eddigis mindazon kemény parantsolatok ellen engedetlenkedtek, és az három határt fel nem állitatták tökéletesen, azért Méltoságos Liber Baro Fő Biro Urunk eo Méltosága, és a Continua Tabla mái Napon Két Vice Király Bíro atyánkfiainak eo Kegyelmeknek meg parantsolta keményen, hogy haladék nélkül mindenik maga processusára ki menvén, az Mely faluk még az három határokat jo moddal és igasságosan fel nem állították, Executiokkal, büntetésekkel mindaddig meg ne szünnyenek, míg eo felsége ebbéli Szent akarattyát nem tellyesittetik. Az mely faluk pedig fel állitották, el bontását azoknak meg ne merészellyék, nagy és kemény büntetés alatt. Mellyeket mindeneknek ezennel adunk értésekre, hogy az kemény Executiokot, büntetéseket el kerülhessék." ${ }^{97}$ Bár a 18. század észleli már a faluközösség alkonyát, autonómiájának - legalábbis viszonylagos autonómiájának - fennmaradását az is bizonyítja, hogy 1820-ban minden rendelet, szabályozási törekvés és fenyegetés ellenére Havasalja mind a tíz falvában kétfordulós a határ. Létezik még a földközösség elemei közül a rétközösség és erdöközösség, és bizonyos értelemben van még közföld, falunyila is. Itt is úgy kell történnie az osztásnak, akárcsak Bágyban, hogy „két nyilat ne bírjanak, mert nem enged meg a Falu edgy nyilnál többet, hogy birjanak". ${ }^{98}$ Az ilyen és ehhez hasonló szabályok is hozzájárulnak a vagyonfelhalmozás gátolásához. (A földközösség korlátozza a módosságot, és teszi ezt a fejlődésnek abban a stádiumában is, amikor a közös szántót már nem osztják periodikusan újra, hisz a kettős vagy hármas vetésforgónak, a közös legelőterületnek köszönhetően fennmarad az ún. termelési kényszer.) A termelés föbb mozzanatait továbbra is a faluközösség határozza meg. Ez a jelenség nem sajátosan székely, nem is sajátosan erdélyi. Analógiákat találunk rá Európa valamennyi paraszttársadalmában, ahol létezett földközösség. J. Thirsk az angol Midland keleti területét kutatva megállapította, hogy a by-law-k (falutörvények, helyhatósági szabályrendeletek) a 12-16. század között világosan bemutatják a közösségi kontroll folyamatát. Ő a közösségi földhasználat alapját a legeltetési jog létében látja. ${ }^{99}$ D.N. McCloskey ezzel kapcsolatban kialakítja a legkisebb kockázatra vonatkozó elméletét. Szerinte a falutörvényekböl világosan kitünik, hogy a közösségi szabályozás célja és lényege mindig a legkisebb kockázat fenntartására irányult. Példaként említi az állatok számának limitálását a tarlón és ugaron való legeltetéskor, ami az állatok fertőzési lehetőségeit csökkentette. Felhívja a figyelmet, hogy már Marc Bloch is hangsúlyozta: a szórt parcellák rendszere a természeti csapások, vihar, szárazság stb. ellen adott védelmet. ${ }^{100}$

\footnotetext{
${ }^{96}$ UszLt. Levéltári mutatók (IV/10.) 1767/14. (A hiányzó irat mutatóbeli tartalma szerint.)

${ }^{97}$ UszLt. Közigazgatási akták. 1778. évi 92. sz. irattartó.

${ }^{98}$ UszLt. Közigazgatási akták. 1711. évi 7. sz. irattartó. 47.

${ }^{99}$ Thirsk, J.: Field System of the East Midlands. = Baker, A. R. H. - Butlin, R. A.: Studies of Field Systems in the British Isles. Cambridge, 1973. 232-280.

${ }^{100}$ McCloskey, D.N.: The Persistence of English Common Fields. = Parker, W. N. - Jones, E. L.: European Peasants and Their Markets. Princeton, 1975. 73-119.
} 
Mindezek után nézzük meg, mekkora volt a 18. században és a 19. század elején a havasaljai szántóhatár, és mennyi jutott átlagban belőle egy családfönek.

Az 1761-62. vetésterület-kimutatás (köbölben és vékában) ${ }^{101}$ :

(XIII.)

\begin{tabular}{|c|c|c|c|c|c|c|c|c|c|c|c|c|}
\hline & \multicolumn{2}{|c|}{ Öszi vetés } & \multicolumn{9}{|c|}{ Tavaszi vetés } \\
\hline & & búza & rozs & búza & zab & árpa & $\begin{array}{l}\text { tön- } \\
\text { köly }\end{array}$ & $\begin{array}{c}\text { ha- } \\
\text { rics- } \\
\text { ka } \\
\end{array}$ & \begin{tabular}{|c|} 
lencse, \\
borsó, zab, \\
kender, len
\end{tabular} & $\begin{array}{l}\text { kö- } \\
\text { les }\end{array}$ & kukorica & Összesen \\
\hline 1. & Oroszhegy & $227-0$ & $17-0$ & $10-2$ & $233-0$ & $2-0$ & - & - & $22-33 / 4$ & - & - & $512-13 / 4$ \\
\hline 2. & Szentkirály & $218-2$ & $10-0$ & $2-2$ & $208-2$ & $0-1$ & - & - & $19-3 / 4$ & - & $0-1$ & $459-3 / 4$ \\
\hline 3. & Ülke & $117-1$ & $13-1$ & $1-0$ & $171-0$ & - & - & - & $12-23 / 4$ & - & $0-11 / 4$ & $375-2$ \\
\hline 4. & Fancsal & $85-3$ & $6-2$ & $0-2$ & $55-2$ & - & - & - & $5-1$ & - & - & $153-2$ \\
\hline 5. & Tibód & $44-3$ & $7-1$ & $2-2$ & $31-3$ & $0-2$ & - & - & $3-31 / 4$ & - & $0-11 / 2$ & $90-33 / 4$ \\
\hline 6. & Szenttamás & $50-0$ & $6-2$ & - & $48-3$ & - & - & - & $3-1$ & - & - & $108-2$ \\
\hline 7. & Zetelaka & $381-0$ & $1-2$ & - & $313-0$ & - & - & - & $52-3 / 4$ & - & $0-1 / 4$ & $747-23 / 4$ \\
\hline 8. & Fenyéd & $153-1$ & $5-2$ & - & $76-1$ & $0-2$ & - & - & $13-11 / 4$ & - & $0-11 / 4$ & $249-1 / 2$ \\
\hline 9. & Keményfalva & $107-3$ & $7-0$ & $0-2$ & $76-1$ & - & - & - & $9-0$ & - & $0-1 / 4$ & $200-21 / 4$ \\
\hline 10. & Máréfalva & $135-1$ & $14-1$ & - & $139-0$ & - & - & - & $21-23 / 4$ & - & - & $310-3 / 4$ \\
\hline & Összesen & $1580-4$ & $88-3$ & $17-2$ & 1353 - 0 & $3-1$ & - & - & $163-1$ & - & $1-11 / 2$ & $3207-21 / 2$ \\
\hline
\end{tabular}

A tíz falu vetésterülete a 18. század közepén 3207 köböl és 2 1/2 véka férejü 1604 kataszteri hold volt. Ez az akkori Udvarhelyszék 1761-62. évi vetésterületének 7,88 százaléka. (A szék összvetésterülete 40676 köböl, azaz 20338 kataszteri hold volt.) Ez a terület Havasalján 619 család között oszlott meg (az 1750-es conscriptio szerint). Ha ezt a földmennyiséget összehasonlítjuk Kászonszék négy falujának szántójával, ami 1761/62-ben 5214 köböl, azaz 2607 kataszteri hold volt ${ }^{102}$ és csak 420 család között oszlott meg, ${ }^{103}$ akkor azt mondhatjuk, hogy a vizsgált tíz falunak nagyon kevés szántója van, még a hegyvidéki falvak rangsorában sem kerülhetnének vezető helyre ebben a tekintetben.

Ez a nem nagy kiterjedésű szántóterület a következőképpen oszlik meg szabadok és szolgáló emberek között:

Egy szabadra eső szántó Havasalján: ${ }^{104}$

${ }^{101}$ 1761/62. évi vetésterület-kimutatás. MOL. Erdélyi Országos Főszámvevőségi Levéltár. F. 394. 1. kötet. 66-69. A vetésterület összeírásában következetlenségek vannak. Például Havasalja tíz falvában 1750-ben jóval több szántót írtak össze, mint 1761/62-ben. A különbség alapján arra is következtethetnénk, hogy 1761/62-ben nem a falu össz-szántóját, csak az abban az évben bevetett területet írták össze. Viszont Kászonban ugyanez a két összeírás más eredményeket ad, 1750-töl 1761/62-ig nem fogyatkozik a bevetett földek kiterjedése, hanem nő. Az ilyen és ehhez hasonló különbségeket az összeírók pontatlansága, illetve az magyarázza, hogy a földmüvelök nem vallották be a teljes földmennyiséget, tartva az elkövetkező magas adótól, úrbértől.

${ }^{102}$ Imreh-Pataki: Kászonszéki krónika. 114.

${ }^{103}$ Ua. 42.

${ }^{104}$ Az adatok forrása az 1722-es conscriptio és az 1750-es nagy adóösszeírás. (Lásd a bevezetés 8. sz. jegyzetét.) 
(XIV.)

\begin{tabular}{|c|l|c|c|}
\hline \multicolumn{2}{|c|}{} & \multicolumn{2}{c|}{ Egy szabadra eső szántó (köböl) } \\
\cline { 3 - 4 } & $\mathbf{1 7 2 2}$ & $\mathbf{1 7 5 0}$ \\
\hline 1. & Fenyéd & 18,27 & 13,00 \\
\hline 2. & Máréfalva & 10,92 & 9,96 \\
\hline 3. & K.Keményfalva & 11,74 & 9,72 \\
\hline 4. & Zetelaka & 8,65 & 7,50 \\
\hline 5. & Szenttamás & 12,50 & 19,10 \\
\hline 6. & Fancsal & 23,07 & $*$ \\
\hline 7. & Szentkirály & 13,13 & 11,70 \\
\hline 8. & Tibód & 12,50 & 9,62 \\
\hline 9. & Ülke & 19,77 & 15,43 \\
\hline 10. & Oroszhegy & 9,66 & 10,72 \\
\hline & A tájegységben & $\mathbf{1 0 , 7 7}$ & $\mathbf{9 , 9 4}$ \\
\hline
\end{tabular}

Egy szolgáló emberre eső szántó Havasalján: ${ }^{105}$

(XV.)

\begin{tabular}{|r|l|c|c|c|c|}
\hline \multicolumn{2}{|l|}{} & \multicolumn{4}{|c|}{ Egy szolgáló emberre eső szántó (köböl) } \\
\hline \multicolumn{2}{|l|}{} & $\mathbf{1 7 2 2}$ & $\mathbf{1 7 5 0}$ & $\mathbf{1 7 8 5}$ & $\mathbf{1 8 2 0}$ \\
\hline 1. & Fenyéd & 7,12 & 5,03 & 3,50 & 3,57 \\
\hline 2. & Máréfalva & 0,62 & 3,00 & 2,41 & 2,75 \\
\hline 3. & K.Keményfalva & - & 3,62 & 7,33 & 15,50 \\
\hline 4. & Zetelaka & 2,37 & 0,90 & 0,48 & 3,25 \\
\hline 5. & Szenttamás & - & - & - & - \\
\hline 6. & Fancsal & - & $*$ & $*$ & - \\
\hline 7. & Szentkirály & 14,52 & 9,00 & 3,86 & 7,61 \\
\hline 8. & Tibód & 3,06 & 12,31 & 3,36 & 2,75 \\
\hline 9. & Ülke & 20,00 & - & 6,25 & 6,50 \\
\hline 10. & Oroszhegy & 10,21 & 8,93 & 8,18 & 4,08 \\
\hline & A tájegységben & $\mathbf{7 , 2 2}$ & $\mathbf{4 , 9 2}$ & $\mathbf{3 , 3 2}$ & $\mathbf{4 , 2 0}$ \\
\hline
\end{tabular}

A conscriptiók tanúsága szerint az egy szolgáló emberre eső szántó nem nagy Havasalján. Vannak néha kiugróbb számszerüségek egy-egy falu esetében negatív és pozitív irányba is, mint amilyen például a zetelaki 1750 -es és 1785 -ös átlag, ami az egy köblöt sem éri el, vagy az ülkei 1722-es átlag, ami 20 köböl. Az egy szabad emberre eső szántó jóval nagyobb, a legkisebb átlag itt a zetelaki 1750-es, ami 7,50 köböl. Mindez azt mutatja, hogy szántóban szegényebb volt a havasaljai zsellér-jobbágy, mint szabadrendü társa. A statisztika számaiból kiderül, hogy a 18. század első felében a különbség még nem haladja meg a 3-3,5 köblöt, de a század közepén az egy szabadra eső szántóföld nagysága már kétszerese az egy szolgáló emberre esőnek, és ez a különbség a 18. század második felében és a 19. század első évtizedeiben sem csökken. Ennek a jelenségnek a magyarázatát voltaképpen már említettük akkor, amikor a társadalmi rétegződésröl, a szabadrendủek dominációjáról szólottunk. Most csak megismételnénk azt, hogy a terméketlen határ, a földközösségben élő faluközösség, az antiqua sessio mint a közföldből való részesedés kulcsa nem kedvezett, nem tette lehetővé a földesúri birtok terjeszkedését Havasalján. A jelenség másik, sajátos arca ebben a tájegységben, és különösen a legnagyobb községben, Zetelakán az, hogy az olyan szolgáló emberek, az olyan jobbágyzsellérek száma nagy, akiknek személyére jogot kapott, jogot formált egy tehetősebb primipilus vagy bebíró földesúr, de telket, appertinentiát, még lakóházat sem biztosított neki. Ezek az

${ }^{105}$ Uo. 
emberek szolgálnak egyezés szerént, máséban laknak, házbért fizetnek, személyileg függőségben élnek, alárendeltek, de nincs jussuk semmilyen falubeli földhöz. 1785-ben például így vallanak a kérdezőbiztosoknak a zetelaki alárendeltek: „A Méltóságos B. Bornemisszáné Jobbágya is jelen nem lévén erről is hasonlóképpen attestálnak az esküdtek, hogy más Házába lakván minthogy Földes ura jószágot Zetelakán nem bír, ház bért külön fizet, jobbágyi taxába pedig fizet esztendönként a Földes uraságnak három Máriást." ${ }^{106}$ „Én Komsa András hasonloképpen más Ember Házába Lakom és fizetek Ház taxát kis Máté István nevü Primipilus Embernek két rénes forintot, mégis az Asszonynak Nyárba minden héten két-két nap szolgálok télbe pedig tsak egyszer másszor." "A „A Füzi Simon ur Jobbágyai jelen nem lévén ugy referállyák a Hitesek, hogy a Földes uroknak itt Zetelakán nem lévén jószága más ember jószágán laknak $\mathrm{s}$ annak külön Ház bért fizetnek, Jobbágyi taxába pedig fizetnek Földes uroknak egy-egy kompona turót, egyebet nem szolgálnak."108

A szántóföld nagyságára vonatkozó 1785-ös és 1820-as adatokról még meg kell jegyeznünk azt, hogy a szántó nagysága ekkor azért is csökkent, mert a parasztok kevesebbet vallottak be. Ez a két összeírás úrbéri conscriptio, segítségükkel a hatalom akarja a maga javára rendezni a földesúr-jobbágy viszonyt. Sem a földesúrnak, sem a jobbágynak nem érdeke ezen a tájon, hogy pontos bepillantást engedjen a központi hatalomnak a tulajdonviszonyokba. A jobbágy, ha nem is elégedett a sokszor csak szóbeli megegyezés, az elödöktől örökölt szokásrend alapján fizetett taxával, robottal, terményszolgáltatással, nem akar más rendet, mert joggal úgy véli, az nem lesz jobb az eddig megszokottnál. Ezért fogyatkoznak meg a földek az úrbéri conscriptiók hasábjain.

A vetésterület nagyságának problematikáját lezárandó néhány összehasonlító adatot szeretnénk még közölni. Ha összehasonlítjuk a Székelyföld hegyvidéki tájegységeiben az egy före eső szántó nagyságát, érdekes eredményhez jutunk.

A megadóztatott mezőgazdasági terület mennyisége és egy családfőre eső átlaga Kászonszékben, Havasalján és Miklósvárszékben 1750-ben:

(XVI.)

\begin{tabular}{|l|c|c|c|c|}
\hline & Szántó köböl & $\begin{array}{c}\text { Szántó holdra } \\
\text { átszámítva }\end{array}$ & $\begin{array}{c}\text { Egy családföre } \\
\text { esö köböl }\end{array}$ & $\begin{array}{c}\text { Egy családfórer } \\
\text { esö hold }\end{array}$ \\
\hline $\begin{array}{c}\text { Kászonszék } \\
\text { (4 falu) }\end{array}$ & 4969,75 & 2484,875 & 11,83 & 5,92 \\
\hline $\begin{array}{c}\text { Havasalja } \\
\text { (10 falu) }\end{array}$ & 5351,00 & 2675,50 & 8,96 & 4,48 \\
\hline $\begin{array}{c}\text { Miklósvárszék } \\
\text { (9 falu) }\end{array}$ & 10292,0 & 5145,875 & 11,55 & 5,77 \\
\hline $\begin{array}{l}\text { Egész } \\
\text { Udvarhelyszék }\end{array}$ & 53286,0 & 26643,00 & 9,70 & 4,85 \\
\hline
\end{tabular}

A kászonszéki és miklósvárszéki átlagokról azt mondhatjuk, hogy azonosak: a három tájegység 23 falujában 9-12 köböl férőnyi szántó jut átlagosan egy családföre, és ez nagyjából megegyezik az udvarhelyszéki átlaggal is, ami 9,70. Ezt a meglepő hasonlóságot, mondhatni azonosságot a hasonló geográfiai feltételeken túlmenően a termelés módozatának hasonlósága

\footnotetext{
${ }^{106}$ 1785-86-os úrbéri összeírás. MOL. F. 51. 24. csomó.

${ }^{107}$ Uo.

${ }^{108}$ Uo.
} 
okozza, a földközösség különböző formáinak szívós fennmaradása, amely túléli a 18. századot és a 19. század első felét is; ehhez hozzáadódik a székely társadalom konzervativizmusa, amely egyaránt magába foglalta a legkisebb kockázatra való törekvés elvét, gyakorlatát és az értékőrzést a gazdasági, társadalmi, kulturális élet bármely szektorában.

Hogy mit termeltek ezen a két fordulóban müvelt, keveset adó földön, azt pontosan megmutatja a XIII. táblázatba foglalt vetésterület-kimutatás. Vetettek őszi, tavaszi búzát, rozsot, árpát, zabot, tönkölyt, haricskát, termesztettek lent, kendert, borsót, babot, lencsét, kölest, és a 18. század második felében nagyon kis mennyiségben kukoricát. „Oroszhegybe az hó néha még a zabot, és más féle gabonájokotis el rontya; annyi gabonája edgyik falunak se terem, hogy meg érje vele" - jegyzik fel 1789-ben az udvarhelyszéki falvak állapottyát felmérő circulatio 12. kérdésére („Mitsoda Gabonát szoktak vetni? meg érie a nép a terméssel és miképpen lehetne módot találni hogy a' magok határokon elvetett termés szaporítassék ha lehet más Gabonával?" ${ }^{109}$ ) a helybeliek. A központi hatalom modernizáló, új növényeket, elsősorban a krumpli vagy a kor szóhasználatában a földimogyoró termesztését szorgalmazó törekvéseire azt felelik: „Az helynek hideg és sovány természete miatt nem terem az földi mogyoró ezen falukba, az Népnek assertuma szerént." 110

Hogy mekkora volt a hozam, milyenek a terméseredmények a tájegységben, mennyit ereszt egy elvetett mag, azt az 1820-as évre tudjuk megmondani, ugyanis akkor a parasztok bevallják, hogy „Gabona termő Határunknak felibe ha vetünk öszgabonát egy vékát terem utána közönségesen 2 Kalangya, a melly ereszt 3 vékát". ${ }^{111}$ Zetelakán, Keményfalván, Oroszhegyen és Szentkirályon 1 elvetett mag 3-at ereszt, Tibódon 4-et, Fenyéden és Ülkén 4,5-t. ${ }^{112}$ Máréfalva az egyedüli falu a tíz közül, ahol a kérdezőbiztosoknak a határ minemüségére nézve azt felelik a helybeliek: „Most kételenségből három határunk vagyon, de jövendöbe kettöt akarunk tsinálni, trágya nélkül semmit sem terem, jó trágyával pedig meg terem búza, rozs, zab, kender. A törökbúzát tsak az egyik forduló termi meg. Két és négy ökörrel lehet szántani. Határunknak mag[ának] harmada nem is trágyázható."113 Itt 1820-ban még mindig háromfordulós a határ, melynek harmadában 3 szemet ereszt egy elvetett szem, másik harmadában pedig 4,5 szemet, az utolsó harmadról pedig csak annyit jegyeznek meg a bevallók, hogy a „harmadik részibe tsak zabot vetünk." ${ }^{114}$ (Ezekbe a hozameredményekbe természetesen beleszámítódik a vetőmag is.) Látható, hogy a Conscriptio Czirakyana elsősorban a búza hozamát veszi számba, a többi gabonára - rozs, zab, árpa, kukorica - vonatkozólag csak kevés vagy éppen szórványos adatot szolgáltat. A terméshozamok számbavételére irányuló kutatások Erdély viszonylatában még meglehetősen szórványosak, kezdeti fázisukban vannak. David Prodan mérte fel a fogarasi uradalomhoz tartozó falvak helyzetét, ${ }^{115}$ Trócsányi Zsolt pedig az

\footnotetext{
${ }^{109}$ UszLt. Nemzeti láda. 1789/94. p. 74.

${ }^{110}$ Ua. 75.

${ }^{111}$ Conscriptio Czirakyana. 1819-1820. MOL. F. 52. 118. kötet. 226-227.

${ }^{112}$ Ua. 226-227, 275, 412; 197, 162-163, 338-339, 450. Fancsalban és Szenttamásban 1820-ban nem írtak össze colonusokat.

${ }^{113}$ 1785-86-os úrbéri összeírás. MOL. F. 51. 23. csomó.

${ }^{114}$ Conscriptio Czirakyana. 1819-1820. MOL. F. 52. 118. kötet. 126-127.

${ }^{115}$ Prodan, David: Urbariile Țării Făgăraşului. II. Bucureşti, 1976.
} 
Északi Partiumét. ${ }^{116}$ Következtetéseik szerint az egyes helységek, járások adataiból elénk táruló kép meglehetősen tarka. A búza hozamának egy-egy járáson belüli szélső értékeire vonatkozó adatok közül idézünk néhányat: Kraszna megye: a kémeri járásban 2,5 és 6, a krasznaiban 2 és 6, a perecseniben 3,5 és 5, a szilágysomlyaiban 3 és 4,5; Közép-Szolnok megye: a szilágycsehi járásban 1,5 és 6 , a zilahiban 1,5 és 5,5 , a péri járásban 2 és 6 , a tasnádiban 2 és 5. Kővár-vidék: a berkeszi járásban 2,6 és 7, a bunyi járásban 2 és 5 , a nagysomkúti járásban 2 és 6 , a vádi járásban 2 és $4 .{ }^{117}$ Ezekkel az adatokkal összehasonlítva Havasalja falvainak terméseredményeit azt mondhatjuk, hogy azok egyrészt egységesebbek, egymáshoz közelebb állóak, alig mutatnak falvankénti eltéréseket, másrészt pedig, hogy az eddig ismert erdélyi terméseredmények viszonylatában egy alsó-középértéket képviselnek.

Havasalja emberei nemcsak szántóvetők, hanem állattartók is voltak. A mezőgazdaságnak ez a két ága, ahol a köves, agyagos határt inkább csak négy ökörrel, mint kettővel lehetett megszántani, szétválaszthatatlanul egybefonódott. A 18. században és a 19. század elején még a rideg és félrideg állattartás dívott itt, ezért volt olyan fontos a tájegység gazdálkodói számára, hogy mekkora a nyomáshatár. Ökrök, lovak, tehenek, hároméves és nagyobb borjak, csikók, juhok, kecskék, disznók - valamennyit tenyésztik a havasaljai tíz faluban, és valamennyi szerepel a korszak adóösszeírásainak fejlécében mint jövedelmet hozó tulajdon. Messze földre eljutott a híres oroszhegyi ló, amelyről Kővári László, Orbán Balázs és mások is szólanak. Már a 15. században a lótenyésztésről híres Alföldön is szívesen tartják a székely lovakat. ${ }^{118} \mathrm{De}$ most nemcsak az oroszhegyi székely lóra figyelmeznénk, hanem szeretnénk számba venni Havasalja állatállományát, felmérni annak gazdasági súlyát és társadalmi rétegek közti megoszlását, melyet mindig részletesen, de minden összeírás alkalmával különbözőképpen jeleznek a conscriptiók. (Van, amikor együtt tüntetik fel igásállatokként a lovakat és ökröket, máskor külön-külön, helyenként minőségüket is jelzik - jó, közepes, gyenge -, általában külön rovata van a „nevendéknek”, azaz a hároméves és nagyobb borjaknak és csikóknak, külön rovat jár a sertéseknek, és egy rovatba vannak írva a juhok és kecskék.)

Ahhoz, hogy az állatállomány különböző elemeit össze tudjuk hasonlítani, s így összevethessük egyik falu állományát a másikéval, egyik tájegységét a másik tájegységével, az állomány különböző elemeit közös nevezöre kell hoznunk, át kell számítanunk ún. számosállatra. (A használt kulcsszámok a következők: szarvasmarha, ló 0,8; juh 0,07; sertés 0,114. Az EMGE statisztikáiban rendszerint egy szarvasmarhát, lovat, két borjút, öt sertést, tíz juhot tekintettek egy-egy számosállatnyi mennyiségnek. Mi az előbbi redukálási módot alkalmaztuk.)

\footnotetext{
116 Trócsányi Zsolt: Az Északi Partium 1820-ban. A Conscriptio Czirakyana adatai. 96-111.

${ }^{117}$ Ua. 96-97. Vannak helységek, mint például a Kővár-vidéki Tornác és Magura, ahol a rosszabb földeken gyakran a vetőmagot sem adja meg a búza.

${ }^{118}$ Idézi Imreh-Pataki: Kászonszéki krónika. 173. Lásd még Hankó Béla: Székely lovak. Kolozsvár, 1943.
} 
A számosállatok megoszlása falvak szerint 1750-ben a következő: ${ }^{119}$

(XVII.)

\begin{tabular}{|c|c|c|c|c|}
\hline & Szarvasmarha és ló & Juh és kecske & Sertés & Összesen \\
\hline 1. Fenyéd & 109,6 & 11,41 & 2,964 & 123,974 \\
\hline 2. Máréfalva & 174,4 & 23,10 & 6,726 & 204,226 \\
\hline 3. K.Keményfalva & 96,8 & 10,08 & 2,394 & 109,274 \\
\hline 4. Zetelaka & 773,6 & 70,84 & 19,608 & 864,048 \\
\hline 5. Szenttamás & 36,8 & 4,90 & 2,166 & 43,866 \\
\hline 6. Szentkirály & 195,2 & 25,27 & 5,244 & 225,714 \\
\hline 7. Tibód & 36,8 & 3,01 & 0,342 & 40,152 \\
\hline 8. Ülke & 96,8 & 10,22 & 2,736 & 109,756 \\
\hline 9. Oroszhegy & 324,8 & 73,50 & 6,954 & 405,254 \\
\hline Összesen & 1844,8 & 232,33 & 49,134 & 2126,264 \\
\hline
\end{tabular}

A számosállatok szerinti rangsorolás 1750-ben nagyjából követi a falvak nagyságrendjét: Zetelaka a leggazdagabb, állatállománya több mint kétszerese az őt követő Oroszhegyének, Oroszhegy után Szentkirály és Máréfalva következik nagyjából hasonló állatállománnyal. A közepes falvak közül Ülke és Küküllőkeményfalva számosállatainak száma majdnem azonos, Fenyéd egy kevéssel előzi meg öket, és ezektől a közepes helységektől is messze lemaradva, a két törpetelepülés, Tibód és Szenttamás zárja a sort 40, illetve közel 44 számosállattal. Nézzük meg, hogyan oszlik meg ez az állatállomány a szabadrendủek és szolgáló emberek között.

Számosállatok megoszlása Havasalján szabadok és szolgáló emberek között 1722-ben ${ }^{120}$ a következő:

(XVIII.)

\begin{tabular}{|l|c|c|c|}
\hline & Szabadok & Szolgáló emberek & Összesen \\
\hline Ökör & 743,200 & 96,800 & 840,000 \\
\hline Ló & 186,400 & 28,800 & 215,200 \\
\hline Tehén + nevendék & 615,200 & 95,200 & 710,400 \\
\hline Sertés & 183,994 & 23,632 & 207,626 \\
\hline Juh + kecske & 311,210 & 48,510 & 359,720 \\
\hline Összesen & $\mathbf{2 0 4 0 , 0 0 4}$ & $\mathbf{2 9 2 , 9 4 2}$ & $\mathbf{2 3 3 2 , 9 4 6}$ \\
\hline
\end{tabular}

Számosállatok falvankénti és rendenkénti megoszlása 1750-ben: ${ }^{121}$

(XIX.)

\begin{tabular}{|l|l|r|c|r|}
\hline \multicolumn{2}{|l|}{} & Szabadok & Szolgáló emberek & Összesen \\
\hline 1. & Fenyéd & 85,104 & 38,870 & 123,974 \\
\hline 2. & Máréfalva & 166,622 & 37,604 & 204,226 \\
\hline 3. & K.Keményfalva & 87,284 & 21,990 & 109,274 \\
\hline 4. & Zetelaka & 778,504 & 85,544 & 864,048 \\
\hline 5. & Szenttamás & 43,866 & - & 43,866 \\
\hline
\end{tabular}

119 1750-i országos összeírások. MOL. F. 50. 61. téka, 3. csomó. Vö. Kiss Albert - Manczel Jenő: A statisztika módszertana és alkalmazása a mezögazdaságban. Bp., 1965. 329-330. „Az állatállomány egészének átlagos nagyságát csak akkor fejezhetjük ki, ha a különböző állatfajok állatait közös nevezőre hozzuk." Az EMGE Venczel József rendszeresítette gyakorlatáról Imreh István tájékoztatott.

${ }^{120}$ 1722. évi összeírások. MOL. Vegyes conscriptiók. F. 49. 12. csomó. 7. tétel.

${ }^{121} 1750$-i országos összeírások. MOL. F. 50. 61. téka. 3. csomó. 


\begin{tabular}{|l|l|r|c|r|}
\hline 6. & Szentkirály & 186,778 & 38,936 & 225,714 \\
\hline 7. & Tibód & 9,994 & 30,158 & 40,152 \\
\hline 8. & Ülke & 109,756 & - & 109,756 \\
\hline 9. & Oroszhegy & 334,152 & 71,102 & 405,254 \\
\hline & Összesen & $\mathbf{1 8 0 2 , 0 6 0}$ & $\mathbf{3 2 4 , 2 0 4}$ & $\mathbf{2 1 2 6 , 2 6 4}$ \\
\hline
\end{tabular}

Táblázatainkban természetesen itt is, mint bárhol az előzőekben, a szabad és a szolgáló ember megnevezés szabadrendü családföt és jobbágy-zsellér családföt jelöl, hisz az adóügyi összeírások őket tüntetik fel. Felületes szemlélőnek úgy tünhetne, hogy a tájegység szolgáló emberei állatállományban jóval szegényebbek, mint a szabadrendủek. Nem szabad elfelednünk azonban, hogy ezek a számok igazán csak az egyes kategóriákba sorolt családfök számához viszonyítva érvényesek, azok függvényében lehet az állatállomány nagy vagy kicsi, és Havasalján az összlakosság túlnyomó többsége szabad székely. A kép teljessége érdekében meg kell mondanunk, mennyi az egy szabad székelyre és egy jobbágy-zsellérre eső számosállat: 1722-ben egy székely 4,73, egy paraszt pedig 4,43 számosállatot mondhatott magáénak; a század közepén, 1750-ben egy szabadrendü családföre 3,82, egy jobbágy-zsellérre pedig 2,70 számosállat jut. A 18. század második felének és a 19. század elejének átfogó conscriptiói, az úrbéri összeírások nem veszik számba az állatállományt.

Az eddig számba vettek alapján Havasalja társadalmáról azt mondhatjuk, hogy a szabadrendủ módosabb volt ugyan szolgáló társánál, nagyobb gazdasági súlya volt a közösségben, de a különbség közte és szolgáló társa közt nem volt olyan, és nem úgy müködött, hogy megzavarhatta volna az egységként létező (és akként is szemlélhető) közösségi létet és annak normáit.

Egy családfőre eső számosállat 1750-ben: ${ }^{122}$

(XX.)

\begin{tabular}{|l|l|l|}
\hline 1. & Fenyéd & 2,53 \\
\hline 2. & Máréfalva & 3,14 \\
\hline 3. & K.Keményfalva & 3,12 \\
\hline 4. & Zetelaka & 3,51 \\
\hline 5. & Szenttamás & 3,65 \\
\hline 6. & Szentkirály & 4,25 \\
\hline 7. & Tibód & 2,67 \\
\hline 8. & Ülke & 3,22 \\
\hline 9. & Oroszhegy & 3,93 \\
\hline & Összesen & $\mathbf{3 , 4 3}$ \\
\hline
\end{tabular}

Amint ideiktatott táblázatunkban látható, egy gazdaságra ebben a tájegységben 3,43, tehát 3-4 számosállat jut, élösúlyban 1500-2000 kg. Ez a szükségleteknél talán kevesebb, de elég sok ahhoz, hogy láthassuk, milyen jelentősége van itt ennek a termelési ágazatnak. Ha ezt az adatot összevetjük a háromszéki és miklósvárszéki átlaggal, megint ugyanazt a meglepő hasonlóságot kapjuk, mint az egy főre eső szántó összehasonlítása esetében.

Az 1750-es állatállomány Kászonszékben, Havasalján és Miklósvárszéken (számosállatra átszámítva): ${ }^{123}$

\footnotetext{
${ }^{122}$ Uo.

${ }^{123}$ Uo
} 
(XXI.)

\begin{tabular}{|l|c|c|c|c|c|}
\hline \multirow{2}{*}{ Tájegység neve } & \multicolumn{5}{|c|}{ Számosállat } \\
\cline { 2 - 6 } & $\begin{array}{c}\text { Szarvasmarha } \\
\text { és ló }\end{array}$ & $\begin{array}{c}\text { Juh és } \\
\text { kecske }\end{array}$ & Sertés & Összesen & $\begin{array}{c}\text { Egy családfóre } \\
\text { esó számos- } \\
\text { állat }\end{array}$ \\
\hline $\begin{array}{l}\text { Kászonszék } \\
\text { (4 falu) }\end{array}$ & 1092,80 & 293,23 & 31,920 & 1417,950 & 3,38 \\
\hline $\begin{array}{l}\text { Havasalja } \\
(10 \text { falu) }\end{array}$ & 1844,80 & 232,33 & 49,134 & 2126,264 & 3,43 \\
\hline $\begin{array}{l}\text { Miklósvárszék } \\
\text { (9 falu) }\end{array}$ & 2496,80 & 305,97 & 104,082 & 2906,852 & 3,26 \\
\hline $\begin{array}{l}\text { Egész } \\
\text { Udvarhelyszék }\end{array}$ & 18888,00 & 2443,49 & 2206,356 & 23537,846 & 4,28 \\
\hline
\end{tabular}

Nem sokban tér el ez az átlag az erdélyi fejedelmi birtokok jobbágy-zsellér népénél 1650-1750 táján regisztráltaktól sem, amely 3,84-4,70 középérték körül mozog. ${ }^{124}$ Ez a történeti statisztika által megvilágított meglepő hasonlóság adalék a 18. századi és 19. század eleji Székelyföld gazdaságtörténetéhez (és egyben ösztönző az összes székely tájegység gazdaságtörténetének hasonló módon, a történeti statisztika módszereivel történő feldolgozásához).

Az állatállomány-örzés vagy éppen -növelés rendkívüli erőfeszítést követelt. A létszámapasztó tényezők között a fö hely a marhadögvészt illeti meg. 1711 és 1741 között sorozatos járványok pusztítanak Erdélyben és így a Székelyföldön is. Az 1711-est Cserei Mihály így örökítette meg: „Soha is senki nem emlékszik Erdélyben, nem is olvasta a históriákban, hogy ilyen szertelen és rendkívül való marhadöge lett volna valaha Erdélyben; annál egyéb kincse sem vala az országnak, az igaz ítéletű Isten azt is elvevé tőlünk a mi büneinkért. Jó lélekkel merem mondani, hogy hárommillió pénznél több kár esett a marhadöge miatt Erdélyben."125 Ilyen nagyméretű marhavészt a század második felében nem jeleznek a források, bár marhanyavalya mindig van, és járásonkénti, falvankénti előfordulására kíváncsi is az abszolutisztikus módszerekkel kormányzó hatalom. Szenttamáson az 1788-as esztendőben kezdődött, és a „marhanyavalyában meg betegedett, meg döglött, vagy megfordult marhák száma” folyó év december 20-án a következőképpen találtatott feljegyezve: „száma a helységbeli marháknak 650, napja a dög kezdetének - 3 octobri, betegségek - 86, megdöglöttek - 46, megfordultak 37." ${ }^{126}$ Az állatállományt azonban nemcsak a vészek tizedelték, hanem fogyatkozott az a rossz, gondatlan bánásmód miatt is, amiatt, hogy az állatot kergették, karóba szöktették, túlhajtással lesántították, rosszul pásztorolták. A havasaljaiak általában annak jó rendje és módja szerint igyekeztek tartani állataikat, hisz nemcsak a földmüvelés folyamatában, a fuvarban, később pedig az állam által követelt különböző szolgáltatásokban - például a forspontban - voltak nélkülözhetetlenek, hanem jövedelempótlásnak, a határ terméketlenségét pótlónak is szánták például a híres oroszhegyi lovat, amely messze vidékekre elkerült; számuk csak azért nem sokasodik a conscriptiók megfelelő rubrikájában, mert az oroszhegyiek eladták azokat.

\footnotetext{
${ }^{124}$ Berlász Jenő: Az erdélyi jobbágyság gazdasági helyzete a XVIII. században. Bp., 1958. 29-30.

${ }^{125}$ Cserei Mihály: i.m. 473-474.

${ }^{126}$ UszLt. Közigazgatási akták. 1789. évi 230. sz. irattartó. 58.
} 
A falu csordában tartotta az állatokat, és gondozásukra pásztort fogadott (marhapásztort, sertéspásztort, juhpásztort). Már a 17. századi falujegyzőkönyvek számos pásztorfogadási szerződést őriznek, de ez a szokás, az állattartásnak ez a módja fennmaradt 1848 után is. Az oroszhegyi falujegyzőkönyv 1857-ben ezt írja a „sertéspásztori fogadás”-ról: „1857. jan. 22-én sertés pásztornak meg fogadtatott az Eskütti és választmányi gyülésben Oroszhegyen Diafalvi Bálint János Ferentz oly formán, hogy mihelyt az idő engedi, a sertéseket hajtsa legeltetés végett, s mind addig őrizze, míglen az idő engedi, továbbá tartozik minden sertésről mely számadásába adatik elszámolni, ha egészen el vesz, megfizetni, ha a farkas által el károsul, s valami jelit meg mutathassa, felit tartozik fizetni - hogyha valami sértődése találtatik valamely sertésnek, betsü szerint tartozik meg fizetni. Fizetése pedig lészen hat sertéstől egy véka gabona, egy kenyér és 6 krajcár botskor pénz, és egy fő kender." ${ }^{127}$ Ugyanazon a falugyülésen tehénpásztort is fogadott a falu. ,Januarius 22-én az Eskütti és választmányi Gyülésben Oroszhegyi Géter Márton megfogadtatott 1857-ik évre tehén pásztornak, kinekis kötelessége leszen 1-ör Mindenkinek tehenit és mind azon marháját őrizete alá venni, a ki számadásába adgya azokot és mindenkinek marháját östére haza hajtani vagy ha el vész, megkeresni, s elvesztése alkalmával rögtön a tulajdonosnak hirtadni, hogy maga a tulajdonos is láthasson a pásztorral a hosszabb keresés alkalmával utánna, $\mathrm{s}$ ha a határon meg nem találtatik, s elé nem tudgya az elvesztett marhát adni, tartozik megfizetni - azonba hogyha a farkas által károsul és valami jegyeit tudgya mutatni, csak felit tartozik meg fizetni. Fizetése lészen: minden négy marhától egy véka gabona, és kettőtől egy kenyér - mindenik darab marhától egy pengő krajcár bocskor pénz a Kitsi bornyus tehénnek egyszeri teje."128

Hasonlóképpen vigyázta, pásztorolta valamennyi havasaljai falu a juhait is, amelyeket - amint előző táblázataink is mutatják - a kecskékkel együtt írtak össze a conscriptorok, és amelyekből szép számmal bírtak Havasalja lakói, szabadok és szolgáló emberek egyaránt. Az aprómajorságot, tyúkot, libát, rucát, pulykát nem írták össze a központi hatalom megbízottai, de tenyésztésükről tanúskodnak a dokumentumok. Ami jövedelemtermelőnek s így az adó szempontjából számba vehetőnek számított még, az a méhkosár volt. Jóllehet a havasaljaiak nem marhának, jószágnak, hanem csak bogaraknak tekintették öket, azért méhészkedtek, hisz 1722-ben a tíz faluban $233,{ }^{129}$ míg 1750-ben már 356 méhkosarat írtak össze. ${ }^{130}$

Az állattenyésztés, még az olyan kis hasznos bogaraknak a tenyésztése is, amilyenek a méhek, szorosan összefonódott ebben a tájegységben az erdővel, ami a földközösséghez tartozóan erdöközösségként, a falu erdejeként létezett. Többször szólottunk már arról, hogy a havason lévő erdök itt ugyanúgy jövedelemforrásnak számítottak, mint maga a szántóföld vagy éppen a tenyésztett állat, de az idevaló, magát földmívelőnek tartó ember mégiscsak jövedelempótlónak mondja. „Pénzt pedig kapunk - a Havasunkból az benne lévő fenyő fákból, Boronafát zsendellyt letzet, szölö karot csinálunk. Deszkát a fürészeinken vágunk Mester embereink kádat, csebret, kártyát, etzetes Hordot tsinálnak és ezeket a szomszéd havastalan Székekben, Vármegyékben visszük el adni és az ezekből béjövő nyereségből pótollyuk Határunk termék-

127 Románia Országos Levéltára Hargita megyei fiókja. Falujegyzőkönyvek. F. 249. Oroszhegy falujegyzőkönyve. 1851-1858. 90.

\footnotetext{
${ }^{128}$ Ua. 90 verso.

${ }^{129}$ 1722. évi összeírások. MOL. Vegyes conscriptiók. F. 49. 12. csomó. 7. tétel.

${ }^{130}$ 1750-i erdélyi országos adóösszeírások. MOL. F. 50. 61. téka. 3. csomó.
} 
telenségit" - vallják a beesketettek 1820-ban. ${ }^{131}$ A fatermékeknek és magának a tűzifának is volt piaca a környéken. „Udvarhely városa egy ora járás distancia lévén minden naturalékot és ha tettzik minden nap tüzre való fát hozhatunk be el adni” - mondják a conscriptoroknak 1820ban az ülkeiek. ${ }^{132}$ Többször említettük azt a tényt is, hogy Oroszhegy Zetelakával együtt Udvarhelyszék legnagyobb erdőbirtokosa. ${ }^{133}$ Használják is a helybeliek tehetségük szerint nemcsak jövedelempótló faárura, hanem az állattenyésztés céljaira, a sertések makkoltatására is. „Mikor a makknak termése van, akkor sertéseink meg híznak, de igen ritkán szokott teremni és mindnyájan osztatlanul közre használlyuk" - hangzik el 1820 júliusának 29. napján Szentkirályon. És ezzel a szentkirályi felesketettek válaszoltak is arra a kérdésre, amelyet fel akartunk tenni: az erdőközösség valóban erdőközösség volt-e, szabadrendűeknek és jobbágyoknak egyaránt? De feleljünk erre még egyszer az egykoron Oroszhegyen vallomást tevők szép válaszával, melyet a néhai tollforgató vetett papírra: „Az itten bébíró Possessor urak emberei minden Erdőbéli Beneficiumot ugy használnak, mint mü székelek mivel itt az Erdő az Élet tartására legnagyobb eszköz s hogy pedig másuva mennyenek erdölni arra nints szükség." 134

Az erdők legfontosabb jövedelempótló termékéről, a zetelaki és oroszhegyi híres zsindelyröl már szólottunk. Idéztük Oroszhegyi Mihály Deákot, aki már 1655-ben megénekelte a zsindelycsinálás felettébb hasznos voltát, tudjuk, hogy Zetelaka ennek a terméknek köszönhette privilégiumát, lévén maga a falu a kortársak szerint valóságos sendelygyár. Szántóföld, állatállomány, fakitermelés, zsindely - ezek voltak a tájegység fő jövedelemforrásai. A szőlő nem terem meg itt, a szőlőskertek összeírására szánt rubrika Havasalja falvainál mindig üresen marad. Ami még adóztatható lenne, az a ser- és pálinkafózés. 1750-ben egyetlen serfőzőt írtak össze a tíz faluban, pontosabban annak a jövedelmét tüntették fel. Ez Zetelakán volt, és a kérdéses összeg mindössze 50 krajcár. ${ }^{135}$ Égettbort a szabályoknak, törvényeknek nem megfelelően is föztek némelyek, amiért is 1789-ben például Küküllőkeményfalván „az Éget Bor Főzésért zállogoltatott meg némelyeket, de még effectumba nem vette a sz. Bíró", ${ }^{136}$ ugyanekkor Fenyéden is ,Égetbor fözésért bursaliter büntették a mi artioba fel vétetett és falu szükségire elis költetett". "37

Nemcsak az égettbor főzését szabályozták rendeletek, hanem az élet majdnem minden szektorát abroncsként fogták össze az intézmények, hisz a társadalom (a társadalmi lét) elválaszthatatlan intézményeitől. A Habsburgok regnálása alatt, különösen a 18. század második felében, egyre érezhetőbbé válik, hogy a hatalom - jelen esetben a közvetlenül felettes hatalom, a szék - autonómiát ad ugyan a faluközösségnek, a legfontosabb intézménynek, de ugyanakkor parancsot is. A nemes Continua Tábláknak a gonosztevők elfogatására kiadott parancsolata a faluközösségre apellál, amely autonóm módon szabályozta és oldotta meg az ezzel kapcsolatos problémáit, kérvén, hogy „ha a dolog ugy kévánná, maga fogná el a káros, az Birák semmit

\footnotetext{
${ }^{131}$ Conscriptio Czirakyana. 1819-1820. MOL. F. 52. 118. kötet. 413.

${ }^{132}$ Ua. 451.

${ }^{133}$ Bedő Albert: A magyar állam erdőségeinek gazdasági és kereskedelmi leírása. I. 318, 513.

${ }^{134}$ Conscriptio Czirakyana. 1819-1820. MOL. F. 52. 118. kötet. 195.

${ }^{135} 1750$-i országos összeírások. MOL. F. 50. 61. téka. 3. csomó.

${ }^{136}$ UszLt. Nemzeti láda 94/1789. 125 verso.

${ }^{137}$ Ua. 126.
} 
nem várván a Tiszt parantsolattyátol, tartozzanak Hazánk Törvénye szerént 200 forint és a Kárnak meg forditása alatt el-fogni" ${ }^{138}$ a gonosztevőt. A hatalom meghagyja a falunak a falusbíró-választói jogot, ,hogy mind a Királlyi Szolgálatnak jobb moddal valo vitelére, mind a Faluk ügyes, bajos dolgainak hasznosabban való igazgatására, minden Faluban az értelmesebb, tehetősebb, és arra alkalmatosabb Gazda Emberek választhassanak Falus Bírákkat"; elengedi a falusbíró adóját: „Eő felsége az illyen értelmes Falus Bírákknak mindennémü adójokat el engedi, fizetvén azt nem a Bíro maga, hanem a Communitás helyette, és ezen Kivül Semminémü Extraordinarium Servitiummal nem terheltetik, sem Executor házához nem száll s Birát maga előtt nem kergeti”; fizetést adott neki, mondván, hogy „a Falu mivoltához és a maga jo viseléséhez képest fizetése rendeztetik". ${ }^{139}$ Megkapja a hatalomtól a falu polgár- és strázsaválasztási jogát is: „minden Faluban a Faluk minémüségekhez és mekoraságokhoz képest választassék a Bíró mellé anyi Polgár, a'menyi elégséges lészen, Kik a szükséges leveleket hordozzák, és a Bíro által ki-adandó parantsolatokat véghez vigyék [...] és a nagyobb Ország Uttyában lévő Falukban fogadgyon a Falu egy strását, ki is mindenkor a Bironál jelen légyen, és a'mint a' Biro néki parantsol, engedelemmel és Serénységgel teljesitse, nem lévén szabad a Bironak ezen strását Semminémü maga különös dolgaira forditani nagy büntetés által.,"140

Természetesen mindezekkel az intézkedésekkel a központi hatalom célja nem a helyi, a faluközösségi autonómia megerösítése volt, hanem a parasztok jobb currentáltatása végett szerette volna megerősíteni ezeket a tradicionális intézményeket, biztossá, a saját maga számára is átláthatóvá, járhatóvá téve minden utat, amelyen az uralkodói parancs az alattvaló felé halad. Ezért bár a szabad választást meghagyja, a biztosabb ellenőrzés érdekében bevezeti a confirmálás, a jóváhagyás gyakorlatát, már nemcsak a széki, hanem a falusi tisztségviselők elsősorban a falusbíró - esetében is: „Falu közönséges Gyülésében votizálván, három Érdemes Subjectumot repraesentáljon Vice Tiszt atyánkfiának, Kik az értelmesebbek azok közül, Confirmállyák." ${ }^{141}$ A régi haszontalan dolgokat, mint amilyen ,az edig valo haszontalan Faluk hegyekről valo egybe Kiáltozásai, melyek nem egyébre voltak, hanem Kiáltozásra, veszekedésre, és néha verekedésre, a dolgok el-igazittása alat valo lármás el-széljedésekre", ${ }^{142}$ szüntessék meg. A falu bírája, a polgár, a strázsa, a tizenkét vagy (kisebb faluban) a hét esküdt, a notárius, a pap, a mester - a falu megannyi tisztségviselője, de még a falu protocollumának vitele is a felsőbb célt kell hogy szolgálja, azt, hogy a felsöbb ordinatiók rendeltetésszerüen vitessenek véghez. „Az éjjeli és nappali őrizések fenn maradására tett rendeletek” még arra is kiterjednek, hogy mi történjék a faluba érkező cigánnyal, aki „Fö Dulló Passussa nélkül elfogassék”, de ha még van is neki, akkor is ,egy Passussal tovább három holnapnál ne érhessen egy Cigány is, ezen Passussbanis specificálva legyenek cselédgyi viszonyai, tyúkjai, Lovai és Ludai és ha a specificalt majorság után vagy Barmoknal többek lenni tanáltatnának, mindgyárt ell fogadtassék és a specificatión kivül tanáltatott marhák vagy majorságok confiscáltassanak". ${ }^{143} \mathrm{De}$ foglalkozik a körültekintő hatalom a silvestris ordo observáltatásával, a tüzoltással és az arra használatos eszközökkel, az utak és hidak állapotjával, a papok kötelességteljesitésével, a

\footnotetext{
${ }^{138}$ UszLt. Közigazgatási akták. 1776. évi 85. sz. irattartó. 8.

${ }^{139}$ Uo.

${ }^{140}$ Uo.

${ }^{141}$ Uo.

${ }^{142}$ Uo.

${ }^{143}$ UszLt. Közigazgatási akták. 1778. évi 92. sz.
} 
pauperum institutummal és azzal, hogy hiszik-e a népek a boszorkányokat, amire vonatkozólag 1789-ben a circulatio Zetelakán felvett protocollumába azt jegyzi fel az írástudó, hogy „vannak még némelyek, a kik affélét hisznek, de meg magyaráztatott nékiek, hogy az afféle gondolatokat le tegyék". ${ }^{144}$ A legfontosabb kérdés azonban nép és hatalom viszonyában, ami meghatározta ezt a viszonyt, az nem más, mint hogy a contributiót miként fizeti az alattvaló, milyen, mekkora ez az adó, és hogy lehet behajtani.

Az „,adómentes”, „kiváltságos” székelység már a fejedelemséggé szerveződött Erdélyországban rákényszerült a pénzügyi tehervállalásra. Adót fizetett, de szenvedélyesen hangoztatta, hogy nem valamiféle kötelességet teljesít, hanem önkéntesen járul hozzá az államháztartás egyensúlyban tartásához. A Diploma Leopoldinum biztosítja ugyan a székelyeket, hogy adótól, kvártélytól, tizedtől mentesek lesznek, ${ }^{145}$ mégis - bár állandóan protestálnak, immunitásukra hivatkoznak - fizetni kénytelenek a rovatalt. 1700-ban például 13000 forint és 5000 köböl búza az, amit el kellett osztani ,inter sedes Siculicales” (a székely székek között), és amelyböl Udvarhelyszékre 3300 forintnyi pénzadó és 1269 köbölnyi naturálé esik. ${ }^{146} 1710$. május 18-án olyan (egyre gyakrabban érkező) rendelettípust vehet kézhez a szék, melyben újból beszolgáltatásról van szó, ezúttal csak búzáról, amiből 350 köbölnyi jutott Udvarhelyszéknek. ${ }^{147}$ Ezt a mennyiséget kell a széki hatóságoknak tovább repartizálni a járások, falvak felé. Minden ilyen és ehhez hasonlóan kivetett adóból a havasaljai falvak is supportálják a rájuk eső részt. 1730 után az úgynevezett calculusrendszerre tért át Erdély. Ennek megfelelően 100 calculusra osztották az adó összegét, és ebből 17 egység jutott a székely székekre. ${ }^{148}$ Ők ezt kis calculusokra bontották tovább, amit aztán az adóalanyokra vetettek ki. Végül az 1750. évi összeírás után Bethlen Gábor udvari kancellár irányításával 1754-ben a bécsi kormánykörök elképzeléseinek megfelelő adórendszer született, az un. Systhema Bethlenianum, amely az 1763-ban (Systhema Buccowianum) és 1769-ben (Systhema Bruckenthalianum) történt módosítások után lényegében 1848-ig érvényben maradt. ${ }^{149}$ A Bethlen-féle adórendszerröl Szádeczky azt írja: „Komplikált adórendszer volt biz' az, melyben eligazodni nem volt könnyü."150

A Havasalja falvaira a 18. század első felében kivetett adó összege forrásaink ${ }^{151}$ szerint a következő képet mutatja:

\footnotetext{
${ }^{144}$ UszLt. Nemzeti láda. 94/1789. 125.

${ }^{145}$ 1549-1848. évi erdélyi törvények. Corpus Juris Hungarici. 495.

${ }^{146}$ UszLt. Közigazgatási akták. 1700. évi 2. sz. irattartó. 47.

${ }^{147}$ UszLt. Közigazgatási akták. 1710. évi 7. sz. irattartó.

${ }^{148}$ Csetri Elek-Imreh István: Erdély változó társadalma 1767-1821. Bukarest, 1980. 17-18.

${ }^{149}$ Szádeczky Kardoss Lajos: A székely nemzet története és alkotmánya. Bp., 1927. 327-333.

${ }^{150}$ Uo. 328. Az új adórendszer szerint Erdély három osztályba (classis) soroztatott a vidékek pénzforgása szerint, minden vidék pedig termékenysége arányában négy kerületre (plaga). A classisok és plagák szerint rovatott ki a fejadó és a különbözö termékek adója.

${ }^{151}$ Az 1722-es, 1748-1749-es adatok az 1722, illetve 1750-es conscriptiókban feltüntetettek. Az 1754es adatokra vonatkozóan lásd UszLt. Közigazgatási akták. 1754. évi 180. sz. irat.
} 
(XXII.)

\begin{tabular}{|r|r|r|r|r|r|r|r|r|r|}
\hline \multicolumn{2}{|c|}{} & \multicolumn{2}{|c|}{$\mathbf{1 7 2 2}$} & \multicolumn{2}{|c|}{$\mathbf{1 7 4 8}$} & \multicolumn{2}{|c|}{$\mathbf{1 7 4 9}$} & \multicolumn{2}{c|}{1754} \\
\cline { 3 - 10 } & Rfrt. & Kr. & Rfrt. & Kr. & Rfrt. & Kr. & Rfrt. & Kr. \\
\hline 1. & Fenyéd & 207 & - & 203 & 18 & 231 & 42,5 & 147 & 24 \\
\hline 2. Máréfalva & 96 & - & 359 & 44 & 448 & 39 & 255 & 48 \\
\hline 3. & K.Keményfalva & 32 & - & 194 & 36 & 246 & 37 & 140 & 11 \\
\hline 4. & Zetelaka & 447 & - & 420 & 27,5 & 378 & 12 & 934 & 56 \\
\hline 5. & Szenttamás & 15 & - & 58 & 2 & 120 & 13 & 57 & 39 \\
\hline 6. & Fancsal & 300 & - & $*$ & $*$ & $*$ & $*$ & 73 & 15 \\
\hline 7. Szentkirály & 132 & - & 255 & - & 317 & 28 & 242 & 53 \\
\hline 8. & Tibód & - & - & 45 & 51 & 48 & 40 & 44 & 57 \\
\hline 9. & Ülke & 33 & - & 233 & 56,5 & 249 & 43,5 & 150 & 45 \\
\hline 10. & Oroszhegy & 216 & - & 393 & 53 & 442 & 7 & 359 & 4 \\
\hline & Összesen & $\mathbf{1 4 7 8}$ & - & $\mathbf{2 1 6 4}$ & $\mathbf{4 8}$ & $\mathbf{2 4 8 3}$ & $\mathbf{2 2}$ & $\mathbf{2 4 0 6}$ & $\mathbf{5 2}$ \\
\hline
\end{tabular}

Az adó állandó növekedésben van. A rovatal nagysága, amint az várható volt, követi a falvak nagyságrendjét. A legtöbbet Zetelaka és Oroszhegy adózik, legkevesebbet Tibód és Szenttamás. A Systhema Bethlenianum már krajcárnyi pontossággal meghatározza, mennyivel fizet többet a szabad székely, mint a jobbágy, de 1750 előtt is így volt ez, a szabadrendü jóval többet adózott úri szolgálatra elkötelezett falusfelénél. Vegyük reprezentatív példának Máréfalvát, ahol az 1750-es conscriptio tanúsága szerint 1748-ban egy szabadrendüre átlagosan 7,08 rénes forint adó esett, egy jobbágyra 2,08, míg egy inquilinus és subinquilinus családfö átlagosan mindössze 1,35 forintot fizetett. A következö évben, 1749-ben - melyet szintén 1750-ben vesznek számba - az abszolút szám, azaz az adó összmennyisége növekszik ugyan, de az arány, a contributiónak a társadalmi rétegek közötti megoszlása ugyanaz marad. Egy szabad székely családföre ekkor átlagosan 8,43, egy jobbágyra 2,66, egy zsellérre vagy ház nélküli zsellérre 1,75 forintnyi adó jut Máréfalván.

Természetesen szép számú a különböző okok miatt mentesítettek serege, a curialistáké elsősorban, akiknek a meghatározása - hogy tudniillik ki számít curialistának - a 18. század folyamán állandóan változik. 1721-ben elkészült például „az egész nagy Udvarhely Székbe található lelkészek, molnárok, harangozók és béresek jegyzéke, akik falvanként minden vagyonukkal a régi összeírások szerint és a falvak korábbi kivonatai szerint mentesítettek". ${ }^{152}$ E szerint a conscriptio szerint Havasalja tíz falujában 29 lelkész, 5 molnár, 1 harangozó és 2 nyomorék özvegye volt mentesített.

A pénzadón kívül súlyosbította a helyzetet a porció, a kvártély és forspont gondja, hisz amint már említettük, a pénzadó csak egyik eleme a contributiónak. A porcióhoz, az egy katona ellátását biztosító adóegységhez mindig társul az élelem- és takarmányszolgáltatás együttese is, a naturálék fizetése. 1702-ben például Havasalja falvai 34 köböl és 3 véka búzát, 156 köböl zabot, 80 és fél szekér szénát, ${ }^{153}$ 1706-ban pedig 107 köböl búzát, 331 köböl és 1 véka zabot, 155 és fél szekér szénát ${ }^{154}$ szolgáltattak be naturáléként. A porciószedést a királybíró szintjén határozták el, a kivetést és behajtást a számadó commissarius igazgatja, de a végrehajtás a communitás tisztségviselöit terheli. Gyakran felparázslik az elégedetlenség a falusbírák és porciót fizető falusfeleik között, a behajtást rágalmazások, gyanúsítások kísérik. A széna,

\footnotetext{
${ }^{152}$ Az 1721. évi összeírások. Vegyes conscriptiók. MOL. F. 49. 8. csomó. 3. tétel. 18-19.

${ }^{153}$ UszLt. Közigazgatási akták. 1702. évi. 3. sz. irattartó. 50.

${ }^{154}$ UszLt. Közigazgatási akták. 1706. évi. 5. sz. irattartó. 31.
} 
gabona árának kiszámítása egy-egy megvesztegethető lajtnan esetében gyakran lesz vádpont: a falusiak a bírót vádolják, hogy az ő kárukra történt a kiszámítás. A hamis mércék használata is igen gyakori vád. A zab- és búzaporciót általában a stációnak kijelölt helységekbe kellett szállítani, ezekben az esetekben a hivatalnokok a szállítást végző szekereseket gyanúsítgatják, hogy útközben néhány köbölnyit eladtak a gabonából.

A forspont, vectura körül tehát alig megszámlálhatóak a visszaélések és az azokkal kapcsolatos különféle panaszok, melyek közül a panaszosok egyesekre a Széknél, a Tekintetes Nemes Officiolátusnál, a vice ispánynál keresik igazukat, mint az a máréfalvi is, aki úgy vette észre, hogy „Máréfalvi Curialis Jószágomban ben Lako fogadot Molnáromat minden vecturákra, forspontokra, és a mire szükség az mostani circumstanciákban minden felé hajtják, és ez nekem igen nagy káromban forog, mint hogy az egész joszágomnakis gondviselése ezen egy fogadott emberemre vagyon bízva, én az én csekély elmém szerint úgy gondolom, hogy mint fogadott cselédemet nem hajthatnák semmi vecturára, mivel ezen cselédemnek magának semmi jószágais Nintsen, melyről kellenék néki szolgálni." 155 Így hát a felmentetteket, a curialistákat is hajtották szolgálatra helyenként, hisz a törvény, a paragrafus helyi alkalmazása igen színes, ritkán egyértelmü, és a fellebbezési fórumok általában messze esnek a jogtalanul porcióztatott falusitól, aki jussát, igazát keresné náluk. Gyakori az olyan példa is, hogy taxás helyek, privilegizált községek panaszolnak a rájuk kirótt adó miatt, mint ahogy teszi azt 1777. október 22-én Zetelaka, mert a Continua Tábla felmentése ellenére újból agraválták a naturalék administratiójával. $^{156}$

A faluközösség mint intézmény felelös a tagjaiért, és ez a felelősség a porciózás kapcsán időnként hangsúlyosabbá válik. Az ülkei communitás egyik instantiájában 1728-ban arra kéri igen alázatosan a fókirálybírót, hogy mivel ,az mü Falunkbul Ulykébül ment el három portiozo Személy, egyik Udvarhelyre, másik Agyagfalvára, harmadik Oroszhegyben, kik is nálunk Economikálnak az portiojuk miszerint maradot, kérjük aként az Méltóságos Urat és az Tekintetes Nemes Széket, azok portiojukat transformálja azon falukba, hová magokat verificaltatták". ${ }^{157}$ A falu felelősséggel tartozott tehát - az adóügy kapcsán pedig fokozott felelősséggel - tagjaiért a székkel, az állammal szemben.

Nem kis nehézséget okozott a különböző speciális szolgáltatások behajtása sem, mint amilyen például az udvarhelyi várbéli katonaság fával való ellátása, ahová Havasalja kilenc faluja (Tibód kivételével) 1741-ben 80 szekér fát szállított. ${ }^{158}$ A kvantum, naturálé, forspont és különleges szolgáltatások mellett a tájegység viselte a beszállásolás és tyro fogás terhét is. A tiszteket Máréfalván szállásolták el, ott volt a quartélyház, ellátva mindennel, a katonaság számára való istállókkal is, melyekbe két-két ló is elfért. ${ }^{159}$

Udvarhelyszék levéltárában számos tyroállítást szorgalmazó rendelet található. Az állam pontosan elöírta, sokszor meglepő részletekig pontosította, hogy milyen katonát kíván. Egy 1778-as rendelet szerint: „Nem kell katonának bé venni a felettébb formátlan embereket, a Kiknek egész vagy fél ábrázattyuk veres fótokkal 's varakkal tellyesek”; „A katona légyen 18

\footnotetext{
${ }^{155}$ UszLt. Közigazgatási akták. 1790. évi. 233. sz. irattartó. 115.

${ }^{156}$ UszLt. Közigazgatási akták. 1777. évi. 88. sz. irattartó.

${ }^{157}$ UszLt. Közigazgatási akták. 1728. évi. 36. sz. akta.

${ }^{158}$ UszLt. Közigazgatási akták. 1701. évi. 2. sz. irattartó. 35.

${ }^{159}$ UszLt. Közigazgatási akták. 1778. évi. 92. sz. irattartó. 28.
} 
esztendőstől fogva negyven esztendősig inclusive, de ha 18 esztendősnél kisebb, negyven esztendősnél nagyobb lészenis, tsak erős tagos, izmos, a hadi szolgálatra alkalmatos légyen bé kell venni”; „A legkisebb Tyronak kell lenni 5 lábnyi és 2 hüvejkni magasságu, ha pedig az ollyan ifjak közül, kiknek nevekedésekhez reménység vagyon, külömben jo erős izmos lészen, az mértéknél egy lineával kűssebb lészenis, bé vétetik; nemzettségbe, vallásba nem kell vállogatni. Tsak Limitaneus Székelly katonákat nem kell bévenni úgy Utonjárokat, kereskedőköt, egyik hellységböl más hellységbe magok vagy urak dolgában jo Passussal járókot nem kell akadályoztatni, annális inkább el fogni, sőtt Senkitis erővel Katonaságra nem kell húzni”. ${ }^{160}$ Katonaságra, bármilyen szépen hangzik is a szék, a falu fórumán megszólaló császári parancs, nem önként mentek az emberek, a tyrókat fogták, különösen Udvarhelyszékben, ahol nem volt határőrkatonaság. A communitás tisztségviselői és a falu szegényebbjei között tyrofogás után mindig kiéleződhetett a feszültség, hisz a szegényebb falusfelek, akik közül kikerültek a tyrók, részrehajlással, megvesztegethetőséggel vádolták általában a falusbírót, azzal, hogy a tehetősebbeknek kedvez. A faluközösség kóbor elemei, a vagik, cigányok szintén gyakran estek áldozatául a tyrofogásnak.

A paraszti hétköznapokat tanulmányozó historikusnak, amikor az adó, porció, kvártély, forspont, tyrofogás problémáit vizsgálja, különösen kell vigyáznia, nehogy kizárólagosan siralmas, nyomorúságos sorsokat lásson és láttasson, nehogy csak azok krónikása legyen. Ez a problémakör viszont - valljuk be - a legobjektívabb vizsgálódás mellett sem tükrözhet sok derüt. A 17. században és a 18. század elején ezek a problémák mindennaposak: az emberek együtt éltek velük Havasalján éppúgy, mint másutt, belefoglalták őket népköltészeti alkotásaikba is: „Vagyon hazánkban két gonosz ember, / Portio Pál és Forspont Péter; / Ez a Portio mindent földhöz vér: / Forspont pediglen ökröt, lovat kér."161

Áttekintettük Havasalja társadalmi, gazdasági, demográfiai viszonyait, legfontosabb intézményének, a faluközösségnek az államhoz, a hatalomhoz való viszonyulását. Előttünk áll egy mikrotársadalom struktúrája, egy modell, a székelyföldi hegyvidéki tájegységek modellje, melynek gazdasági, társadalmi, demográfiai sajátosságait részletezően elemeztük.

Havasalja társadalma többségében szabadrendủ társadalom. A szabadrendủek száma itt meghaladja a 60, esetenként a 70 százalékot is. Lakosai, bár a havas aljában élnek, rossz minőségü földön gazdálkodnak, mégis egységesen földművelőknek mondják magukat. A tájegység valamennyi falvában léteznek és müködnek a földközösség különböző formái, a szántóközösség, rétközösség, erdőközösség. A föld müvelési technikája azonos a tájegység valamennyi falvában (kettős nyomásrendszer, esetleg a 18. század vége felé elszórtan hármas vetésforgó). A lakosság eltartásához a földmüveléssel egyenlő, esetenként nagyobb mértékben járul hozzá az állattenyésztés és a jövedelempótló famesterségek, melyeknek nyersanyagforrása az erdő. A nagybirtok nem itt tud gyökeret verni.

Ezek a vonások - mivel itt modellről van szó - valamennyi székely hegyvidéki, havasalji tájegység esetében fellelhetőek. Természetesen számítanunk kell bármely más tájegység esetében eltérésekre, az átlag körüli szóródásokra, ami azonban nem akkora, hogy megkérdőjelezze a modell érvényességét. Havasalja gazdasági elemzése - az egy före eső szántó-, illetve az egy családföre jutó számosállat-mennyiség - során néhány (sokszor megdöbbentő) hasonlóságot

\footnotetext{
${ }^{160}$ UszLt. Közigazgatási akták. 1778. évi. 92. sz. irattartó. 3.

${ }^{161}$ Idézi Imreh-Pataki: Kászonszéki krónika. 222.
} 
már bemutattunk. A felsorolt tényezőket a hegyvidéki tájegységek egész 1848-ig konzerválják. Konzervatív, de ugyanakkor értékőrző társadalmak is. A székely faluközösség alkonya ezekben a tipikusan hegyvidéki földrajzi adottságokkal rendelkező tájegységekben tovább tart, és végkifejlete később következik be, mint a kedvezőbb természeti adottságokkal rendelkezőknél. 


\section{Függelék}

Ebben a függelékben az udvarhelyszéki Havasalja néhány falujára vonatkozólag az 1713, 1785-86. és 1820. évi úrbéri összeírások anyagát közöljük.

A közlés módjával kapcsolatban a következöket kell elörebocsátanunk:

A jegyzőkönyvek közül az 1713-as és az 1785-86-os párhuzamos (latin-magyar) szöveggel készült. Itt viszont csak a magyar nyelvü rész közlésére szorítkozunk.

A jegyzőkönyvek szövegéből - a szövegismétlődést elkerülendő - kiemeltük a kérdezőbiztosok típuskérdéseit; azokat az egyes években megejtett úrbéri összeírások élén közöljük, míg a falvaknál csak a feleleteket.

A szövegközlés során lemondtunk az egyes jegyzőkönyvek latin nyelvü preambulumainak közléséröl. A jegyzőkönyvek záradékában ugyanis még egyszer megtalálható a kérdezőbiztosok neve, a falubeli „hites emberek" névsora, valamint a jegyzőkönyv felvételének helyére és időpontjára vonatkozó adatok.

A jegyzőkönyvekben használt rövidítéseket $($ Sz. Király $=$ Szentkirály, L.B. $=$ liber báró, tit. $=$ titulatus, Mlgs. = méltóságos, ag. $=$ agilis, ttes $=$ tekintetes, flor.ung. $=$ florenis ungaricalis stb.) feloldottuk.

A közölt szövegek helyesírását a mai helyesírási szabályokhoz közelítettük, megőrizve azonban a nyelvjárási és a korabeli nyelvállapotra utaló sajátosságokat.

V.M. 
1713. augusztus 24., h. n.

\author{
Az Erdélyi Főkormányszék utasításai az 1713. szeptember 14-én az adóösszeírásra \\ kiküldendő vizsgálóbiztosok számára \\ Eredeti: az Országos Levéltár Kolozs megyei Igazgatósága (Arhivele Naționale. Direcția \\ Județului Cluj). Udvarhelyszék Levéltára, Székely láda, 21. sz.
}

\title{
Instructio
}

pro investigatoribus commissariis pro die 14 mensis Septembris anni currentis 1713 exmittendis expedita.

1: Mindeneknek elötte investigator uraimék ökegyelmek az elejekbe adandó hitnek formulája szerént hiteket le tegyék és az hova investigátióra mennek, azon vármegyéből, székből, várasokból rendeltetvén melléjek olyan értelmes jólelkü emberek, kik annak elötte vagy tisztségban voltak, vagy ha nem is, de az helynek mivoltát tudgyák, sőt az hol kívántatik a commetaneus faluk öreg hiteles emberei közzül hármat vagy négyet pro certiori indagino convocállyanak, kiket is meg eskessenek és az tisztektől kezekben vééndő regestrum szerént falunként magokkal hordozzanak, hogy a mi kívántatik igaz informatiót tehessenek.

2: Investigátor uramék minden városokat, falukat és azoknak határit elsőbben megjárják, mind ez okon, hogyha valami csalárdságot akarnának el követni az lakosok az investigátiónak idején, elő nem akarván mondani szöleit, szántóföldeit, szénafüveit és egyéb minden haszonvevő hellyeit, hogy az nagy és tapasztalható hazugságokot meg ismerhessék és ne admittállyák, mind penig hogy az hellyeknek minden qualitásit, jó és rossz voltát megszemlélvén írásban igaz informátiót tehessenek rólla.

3: Fel kell írni az hellyeknek situssit, földnek termékeny vagy terméketlenségét, ide értetvén az irtoványföldek is, a mellett szükség felírni, hogy ennek vagy amaz városnak, falunak határa délre néz-e inkább vagy északra, vizes-é vagy száraz, az föld fekete-é, agyagos-é vagy fövenyes, hány ökörrel szántható, kétszeri szántásban vetnek-é vagy háromszoriban, ganéjozzák-é az földet vagy nem, hány fordulója vagyon, kettö-é vagy három, ha határa vagyon is az colálásra alkalmatos-é vagy nem, jól felvizsgálván mindazonáltal qualitását az határoknak, réttye is, szénafüve is mennyire vagyon, tiszta buzát terem-é az határ avagy elegyest vagy csak rosot vagy nagyobbára tavasz vetést, és azt is inkább zabot, mint őszvetéseket. Határokat másoknak nem zálogosították-é el, és ha elzálagosították, mennyit s kinek és most kik bírják. Vagyon-é folyóvize, tója halászatra való és kereskedését gyakorolható-e vagy nincsen és ha káros folyóvize vagyon, mennyire káros. Malma a maga határán vagyon-é és ha vagyon, az falujé-e vagy valami adózni tartozó emberé, vagy dominus terrestrisé és mindenkor forog-é, vagy nem, jó haszon hajtó-é vagy nem és ha nincsen, hány méllyföldnyire kell malomban járni. Erdeje vagyon-é vagy nincsen, és ha vagyon, elegedendö-e vagy nem maga tüzire, azonkívül makktermö és épületre való erdeje vagyon-e vagy nincsen. Réttje vagy szénafüve minemủ vagyon, szölőhegye is vagyon-é vagy nincsen, és ha vagyon, jól termö-é vagy rosszul termö és jó bort-é vagy rosszat terem. Marsusban vagyon-é vagy nincsen és micsoda gradusban, városhoz közel vagyon-é az falu az holott egyetmásit eladhatván kereskedésit üzhesse, búzájából, szénájából és egyéb oeconomijájából. Valami bányája vagy hámora vagyon-é, az városnak falui, jószági vadnak-é és minémü proventussi és azon falukból minémü haszonvehető házai, korcsmái és sokadalmi proventussi. Minemü kereskedésnek módgya, egyszóval micsoda jövedelmi lehetnek annak az városnak, ide nem értvén az dominus terrestrisek és jószágos nemesemberek szőlői, szántóföldei, szénafüvei, réttyei, tilalmas erdei, tavai, malmai és akarminémű haszontévő hellyei az uraknak és nemesembereknek, úgy az hétbíráknak vagy más szász vagy magyar városoknak, ha találtatik az vármegyében valami jószágok, abban lévö olly majorságföldei, szölei, réttyei, malmai vagy egyéb hasznot adható appertinentiái, mellyeket ugy mint dominus terrestrisek bírnak és usuálnak, az minémüek bolkácsi, sitvei, szebeni rész és több jószágok az mellyek az szász nátióval tött contractusban az őkegyelmek jurisdictiója alá bocsátották, de azelőtt az vármegyékhez tartoztak. 
4: Noha az egyházi nemes ember csak az ő szegénysége miá nem tetethetik alábbvalóvá quoad jus et praerogativam nobilitatem az jószágos, gazdag, úr, fö, nemesembereknél, mindazonáltal mivelhogy az Compilátabéli üdőtől fogva, minden koron contribuálni szokott volt, azért az egyházi nemes emberek dolga investigátiójában így procedállyanak. Ebben az faluban vagy városban, aminémü Sárd, Igen, Benedik, Déva, Hunyad, Hattzeg, Fejérvár, Vincz, Borberek és több hasonló taxás, rész szerint nemes, rész szerint jobbágyból álló városok; egyházi nemes ember hány vagyon, kinek híjják, maga nemes fundussán lakik-é vagy parasztfunduson, bír-é ezen falu vagy város határán valami paraszt fundus után járó szőlöt, szántóföldet, rétet vagy valami akármi névvel nevezendö haszonvévő hellyet és alkalmatosságot az illyént fel kell írni; de ha mit maga nemes fundussa után bír, azt nem kell felírni. Ezt az egyházi nemes emberek regestrumát külön kell írni, és a parasztok regestrumában nem kell elegyíteni.

5: Enyed, Thorda, Deés, noha nemrégen egészszen nemessé löttek, és így talám vendicálhatnák azt magoknak, ami ide fellyebb az egyházi nemes emberek nemes fundussának és ahhoz tartozó nemes földeknek, appertinentiáknak fel nem iratása felöl iratott, de mivelhogy az említett városok ma is per jus regium másoknak adatott dézsma- vagy quárta adással tartoznak, azért mind külső appertinentiájoknak, mind belső facultasoknak, kinek-kinek meg kell vizsgáltatni és fel iratni, nem illettetvén mindazonáltal azok az házak, amellyek azokban az várasokban a várasoknak egész nobilitátiója elött is nemes és exemptus házak voltak, sem azok, az kik az ország eddig bévött rendtartása szerint ha rovatallyok vagyon s arról contribuálnak és így egyházhelyi nemesember számban nem tartatnak, ide értetik Kolozsvár várossa is, ha szintén nobilitátiójából régi civilis statussára redeált is, hogy ott azoknak az házok, mellyek ante nobilitationem cum jure regis exempták voltak, ne irattassék fel.

6: Tudott-e ebben a faluban vagy városban vagy székben vagy vármegyében kicsodák az kik az adózásból, portiózásból és egyéb közönséges teherviselésből exemptusok löttek volna ezekben az elmúlt esztendőkben és micsoda mértékben és mint löttek az ollyan exemptiok, ki czidulájával vagy authoritássával.

\section{Az nemes székely nátion való modálitásról}

7: Valamint az Vármegyéken az jószágos urak, fő és rovatalról contribuálható nemesembereknek semmi jószága fel nem iratik, úgy az Székelységen sem. 2: Hasonlóképpen az armálisok, egyházi nemes emberek is per omnia úgy investigáltassanak, az mint a vármegyéken az egyházi nemes emberekről írtuk articulo proximo $4^{\text {to }}$. 3: A lofó és darabonti rend az szerint investigáltassék az mint az Thordai, Enyedi, Deési, egyházi nemesség. 4: A Jobbágyság amint a vármegyéken lévö jobbágy az szerint.

8: Mivelhogy in genere az egész országban a városi embereknek akár magyar, akár szász városok légyenek, az értékek nagy részén nem az mezei és marhabéli alkalmatosságban áll, hanem a kereskedés, kalmárság és kézi mesterségben, azért investigátor uraim akiknek mind belső, mind külső értékek találtatik, azt az szerint, akiknek penig semmi külsö értékek nem találtatik, a belsöt minél szorgalmatosabban lehet investigállyák, hogy kinek kinek hasznot hajtható háza, boltja, kereskedése és egyéb akármi alkalmatossága hány száz, vagy ezer forintig való hasznot hajthat esztendönként ordinarie, mint erről odafel is in $3^{\text {tio }}$ puncto emlékeztünk.

A városoknak penig in mensura, majori vel, in genere kereskedésre való alkalmatossága más országból micsodás, sokadalminak, hetivásárinak, város számára való bor, ser korcsmáinak, vámos hídgyainak, havassinak, malmainak és egyszóval akármi egyéb közönséges jövedelminek alkalmatossága mennyire terjedhet, cum circumstantiis per dominos investigatores pro renata deprehendendis uti et superius $6^{\text {to }}$ puncto meminimus. Vadnak-é a városokban sive respectu officiorum universorum, sive ordinis ecclesiastici, vel scholastici, vel alios ob quales comque respectus exemptusok és micsoda mértékben, mennyi üdőtől fogva. Ez az $8^{\text {dik }}$ punctum és odafel az $3^{\text {dik }}$ punctumnak az vége illeti az becsületes szász nátiot is a Városok iránt. Ami pedig

9: A Regius Fundusokon lévö falukat illeti, mivel ott nemes fundus igen kevés találtatik, úgymint Margondán, Halmágyon vagy másutt akárhol, ha ollyan találtatik, ollyant ki hagyván, minden Regius Funduson lévö Faluk lakossinak nemit, mivoltát és minden külső, belső értékeket fel kell irni, szintén úgy, mint az vármegyén lévö vármegyei jobbágyrendeket, nem csak az valóságos és állandó lakossit penig az falunak, hanem akármi 
alkalmatosságokkal élö, lakó, kereskedő vagy tekergő selléreket és vándorembereket cum omnibus illorum vivendi modis et mediis, aminthogy ennek a vármegyéken, Székelységen és városokban is mindenütt így kell végben menni cum hac observatione, hogy az illyen sellér, vándor, minden faluban az örökös emberek után külön classisban irattassék.

His generalibus praemissis in particulari

10: Meg kell kérdeni, hogy hány egész paraszt házhely vagyon azon faluban, akik után nyilat szoktak adni, szántóföldből, szénafüből és erdőből.

11: Végére kell menni hitelesen egy embernek hány hold szőlője vagyon, hány ember kapálhatná meg egy nap, minémü bora terem és középárán, mennyin adhattják el vedrit és terméketlenségben, a középtermésnek idején hány vedret terem. Hasonlóképpen hány köbölre való szántóföldje vagyon és hány szekér szénát termő szénafüve vagy réttye, és nominanter ez mostan tilalmosban lévő fordulóra hány köböl vetése vagyon mindenféle, ide nem értvén az nemes földekben való vetésit az paraszt embereknek, úgy az nemes és szénafüvekben termett vagy teremhetö szekér szénákot, úgy mindazonáltal, hogy az ki eddig nemesföld nem volt, hanem parasztföld volt most nemesföldé ne csinállyák, ezen investigátiónak alkalmatosságával, hogy ez mostani investigátió ne defraudáltassék vélle.

12: Meg kell tudakozni, hogy abban a faluban vagyon-e valami tekergő ember aki sem jobbágy sem sellér és semmi külsö appertinentiákat nem bír, hanem valami kézi munkájával vagy kereskedésivel élő ember, és ha vagyon, mennyire extendálható kereskedése és értéke lehet, az pedig akar micsoda nátioból álló légyen, fel kell írni minden értékével és kereskedésével. Ide nem értvén az egy cigány nemzettség. Az urak, förendek, udvari jobbágy cselédgyek penig az kiknek az urok csináltat házat és ház után nyil földeket nem bír, külön regestrumban irattassék fel.

Szükség ennek felette annak is szorgalmatoson végire menni, ki mennyivel, kinek és mioltátúl fogva adós, abba $\mathrm{s}$ annak interessében mennyit s mikor fizetett, miképpen szokta interessezni és még mennyivel adós.

Hogy penig ezen investigatió alkalmatosságával minden fraus és dolus praescindáltassék, meg kell azt is vizsgálni, ki hadta el maga előbbi lakóhelyit és mikor, volt-é ott oeconomiája vagy valami facultássa, mellyet elöbbi hellyén hagyott volna, és maga vagy más inductiójából indíttatván ment-e el, gabonáját kire bízta vagy adta, vagy ki által hová takaritotta és most hol s miképpen vagyon. Efelett

A Dézmaadó hellyeken observálni kell, hogy a dézmákról való hiteles extractusokot kivánnyák és kérjék elö őkegyelmek, mellyeket az falukbéli praedicatorok, bírák és esküttek fide mediante tartoznak producálni.

13: Hogy penig az Isten látogatását nagyobb mértékben az sok hamis hittel ez szegény hazára ne vonnyák, nem kell az parasztembereknek hiteket pro fundamento fel venni, hanem minden helybéli vicetisztek sub amissione honoris et officii, hogy az falukra mennyi quantumot vetettenek akármellyik nevezetes adóból, tartozzanak kiadni és az szerént annak szorgalmatoson kell végére menni, hogy egy nyílföldre mennyi esett abból az adóból, és ha szintén az paraszt emberek ki nem akarnák adni azt, hogy mennyi esett volna egy nyílra, de a parte végire kell menni, füstre és marhára mennyi esett és így ugyan kitanulhattyák mennyi az szántóföld, sőt az hol lehet a falunak rovásit és az városok regestrumit előhozassák, hogy abból ha mire végire mehetnek szorgalmatoson munkálodgyák, nem kötvén mindazonáltal azt is ki, hogy az hol szükség, nem csak az falusbirókat, de az embereknek értelmesét is meg eskessék. Ha hol penig aziránt valami fraust tapasztalnának, sine omni remissione, az illyenekben impingalón 40 forintot exequállyanak, kiről is regestrumok légyen, hogy hol mit exequálnak, hogy azon mulcták az ország adójában mennyenek akinek penig pénze és annyira való értéke nem lészen, az 40 forint helyett hatvan pálczát adgyanak néki.

Ad mandatum Excelsi Regii Gubernii Transilvanici

Die 24 Augusti 1713. Extradata per

Samuelem Alvinczi mp. 
Tibód, Szentkirály, Ülke, Oroszhegy falvak leírása az 1713. évi összeírás során

MOL. F. 49.

\section{Descriptio possessionis Tibold}

Situssa hegyes völgyes, oldalos, ganyézással termékeny, délre áll. Száraz és vizes, köves, két fordulója vagyon, rétye és széna füve nincsen, elegyes búzát terem, zabot terem a tavasz vetés, négy ökörrel szántyák, határokat nem zálogositották el. Folyó vizek kis patak, másuva járnak malomban fél méjföldnere, hitván cseplyes erdejek, makkos erdejek is vagyon a havason magok számokra. Városhoz fél méjföldnere laknak, semmi kereskedések nincsen, hanem tüzre való fából valamit... Adósok florenis 51. templom számára és küvül való embereknek. Interessit fizetik egy napi dologgal vagy denariis 12 .

Exemptus senki.

\section{Descriptio possessionis Szent Király}

Situssa hegyes-völgyes oldalos, köves, ganéjzással termékeny, délre áll nagyobbára, földe száraz inkább, vizes is van. Két fordulója. Réttye kevés, elegyes búzát terem, tavaszvetés zabot terem. Határokat nem zálogosították másnak. Folyó vizek kicsin patak, malmok nincsen. Fél méjföldnére járnak malomban. Tüzre való fájok elég, makkos erdejik is vagyon, épületre is. Városhoz fél méjföldnére vadnak. Városra tüzifát visznek eladni, azzal kereskednek. Gyümölcs fájok is vagyon. Exemptus egy asztalos vagyon, hogy ha az Szék szükségire kivántatik, oda dolgozik.

Adósok florenis ungaricalis 300. Interesse denarii 9. Templom számára. Erdejik extendálódik fél méjföldnére a hossza.

\section{Descriptio possessionis Ülke}

Situssa ezen falunak oldalos, völgyes, ganyézással egyik határa jó, termékeny, a másik úgy is sovány. Egyik határa délre, másikja északra néz. Száraz egyik határa, másikja vizes. Fekete föld egyik határa, másikja sárga agyagos, négy ökörrel szántható, kétszeri szántásban vetnek, két fordulója vagyon. Réttye nincsen, széna füve kerttel, melyet is tartanak nagyon kevés. Elegyes búzát terem, zabot terem, tavasz vetések, azt is ganyézással. Határokat nem zálogosították. Folyóvizek kicsin patakocska, malmok nincsen, fél méjföldnére járnak malomban. Makktermö, épületre való fájok havason vagyon magok szükségükre, tüzifájok maguk határokon kevés. Városhoz fél méjföldnire laknak. Csebret csenálnak eladni, tüzifát visznek eladni. Exemptusok nincsenek.

Adósok florenis 392. Interesse modalitas denarii 12. Marsusban nincsenek.

\section{Descriptio possessionis Oroszhegy}

Situssa ezen falunak oldalos hegyes-völgyes, ganyézással közép szerint termékeny egy része határoknak, más része köves, határa nagyobb része délre néz, harmada északos, nagyobb része száraz, közben források és fokadások vadnak, a földe veres, fejér agyagos, négy ökörrel szántanak kétszeri szántásban vetnek. Két fordulója vagyon. Rétye nincsen, szénafüvük vagyon határokon, erdejeken is. Elegyes búzát terem, tavasz vetési zabot inkább. Határokat másoknak nem zálogositották. Folyó vizek egy patakocska. Az erdön vagyon egy fürész akin deszkát metszenek egy méjföldnére a Küköllö folyamján. Malomban szárazságnak idejin fél méjföldnére járnak. Erdejek elég vagyon melynek is egy méjföld a hossza és fenyő erdejek, tűzre való fájok is elegendö. Városok egy méjföld. Tüzifával, deszkával, zsendellyel kereskednek, léccel is pénzek után kereskednek. Marsusban nincsenek. Exemptus nincsen.

Adósok florenis ungaricalis 300. Creditores Ugron István urunk, azomban ittvaló falusi emberek.

Interesse solvent egy napi dologgal, item denarii 10. 


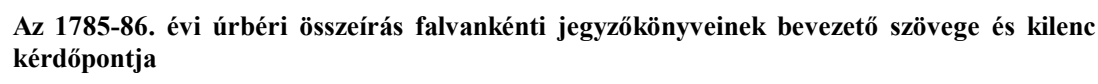

Examen ad novem puncta interrogatoria in possessione... inclyto comitatui Udvarhelly adjacente in praesentia judicis ejusdem possessionis [...] et juratorum [...] singulorum libertinorum siculorum reliqorumque incolarum ac dominorum terestium qui ad praesentem operationem venire non praetermiserunt, anno ... institutum et peractum,

\section{Puncta interrogatoria}

\section{[A kérdőpontok:]}

$1^{\text {sö } V a g y o n-e ́ ~ m o s t a n s a ́ g ~ u r b a ́ r i u m a ~ e z e n ~ h e l l y s e ́ g n e k ? ~ h a ~ v a g y o n, ~ m i n e ́ m u ̋ ~ a z ? ~ m e n n y i ~ u ̈ d o ̋ t o ̋ l ~ f o g v a ~ h o z a t o t t ~}$ bé?

$2^{\text {dik }}$ Ha urbáriuma nincsen a jobbágyi kötelességet teszik-é contractus szerént mind a jobbágyok, mind a zsellérek? mennyi ideje már annak, hogy azon bévett szokás kezdődött, avagy contractusra lépett ezen hellység a földesurasággal? Nemde nem ezen urbárium vagy contractus tétele előtt is voltanak mások és ha voltak, minémüek és mikor kezdödött ezen mostani szokásban lévö kötelességnek praestatiója?

$3^{\text {dik }}$ Az hol urbáriumok vagy contractusok nincsenek, miből álló a jobbágyságnak és zselléreknek földesurok számára való praestatiója, szolgálattya és kötelessége, amelly mostanság szokásba vagyon, mikor és mi módon hozatott bé azon kötelesség és adózás?

$4^{\text {dik }}$ Minémű haszonvételei vannak ezen helységnek és határjainak? avagy ellenben minémü károk szokták közönségesen érni a helységet és határját?

$5^{\text {dik }}$ Hány és minémű szántóföldgye és réttye vagyon egy egész házhellyes gazdának és hány szebeni vékát vethet edgyik hold szántóföldgyébe? Ollyanok-é réttyei, hogy kétszer is lehessen kaszálni?

$6^{\text {dik }}$ Minémű és hány napi munkát vitt egy-egy gazda eddig végben és hány vonómarhával? és amidőn robotra mentek és visszajöttek, bé számláltatott-é azon járásnak-kelésnek ideje is a napi számhoz?

$7^{\text {dik }}$ Adnak-é az itt való lakosok a földesuraságnak kilencedet? ha adnak, minémű termésből és javakból adgyák azt? s mennyi üdőtől fogva? és vagyon-é a kilencedbéli adózás ezen nemes vármegyében más földesuraságnál is bévett szokásban? ezen kívül más adózás fejében mit szokott ekkoráig egy-egy jobbágy adni esztendönként az uraságnak, nevezetesen pedig ollyatén, akár készpénzül, akár más egyébböl adatott praestatio és ajándék miből álló volt?

$8^{\text {dik }}$ Hány pusztahelly vagyon ezen hellységben? mennyi üdőtől fogva? mi okból pusztultak el? és azon hellyeket appertinentiáival edgyütt kik bírják?

$9^{\text {dik }}$ Ezen hellységnek lakossi örökös jobbágyok-é vagy nem? 


\section{5. október 26. Oroszhegy}

\section{Az oroszhegyiek válaszai az úrbéri vizsgálat kilenc kérdőpontjára}

MOL. F. 51.

\section{Responsio}

$\mathrm{Az} 1^{\text {sỏre }}$ nintsen urbárium nálunk.

$2^{\text {dikra } I t t e n ~ s e m m i ~ u r b a ́ r i u m ~ v a g y ~ c o n t r a c t u s ~ n e m ~ l e ́ v e ́ n, ~ r e ́ g e n ~ u g y a n, ~ m i k o r ~ m a ́ s ~ f o ̈ l d e s u r u n k ~ v o l t, ~ k o ̈ n n y e b b ~ v o l t ~}$ a mi jobbágyi szolgálatunk, hanem már 13 esztendőktől fogva terhesebb és inkább meg kéványák a szolgálatot; ezelött is semmi egyezés nem volt mi és az uraság közt.

$3^{\text {dikra }}$ Mi kik Török Pál uram jobbágyi voltunk, gyalogszerbe minden héten három nap szolgáltunk, marhával pedig télbe-nyárba kétnapi szolgálatot tettünk egy héten. Mi pedig oláh jobbágyi Diffán Péter és István, kik juhpásztorsággal élünk, heti szolgálatot nem tettünk, hanem esztendőre adtunk két kompona turót és némellykor egyéb szolgálatot is tettünk, melly együttvéve esztendőnként megtett volna 5 magyar forintokot. Mi a méltóságos liber báró Henter Antal úr jobbágyi minden esztendőben 6 magyar forint taxát adtunk. Én pedig Czincere András nem lakván földesuram jószágába, minden esztendőben 3 magyar forintokat adtam. Én, Szombatfalvi János uram jobbágya, midőn nyárba és ősszel dolog ideje volt, két, s némellykor három hétig is szüntelen az uram udvarába tettem a szolgálatot $\mathrm{s}$ télbe is egynéhány szekér fát vittem $\mathrm{s}$ egyébkor semmi szolgálatot nem tettem. Én, Ugron Andrásné asszonyom zsellére minden esztendöre adtam 4 báránt és két sajtot. Én János Máté Regius Fiscus jobbágya esztendöre adtam 2 rénes forintot. Mi titulatus Török Elek uram jobbágyi félannyi szolgálatot tettünk, mint a Török Pál uré. Én Tibád Ferenc uram jobbágya, nem lakván az uramnak jószágán, minden esztendőben két kompona túrót adtam földesuramnak. Ételt pedig nékünk mindnyájunknak, mint jobbágyoknak, mint zselléreknek midőn úrdolgára mentünk, földesuraink adnak ételt.

$4^{\text {dikre }}[\ldots]$

$-1^{\text {re }}$ Határunk kettő vagyon, mellyeknek edgyütvéve a negyedik része a tiszta és elegyesbúzát, úgy a rosot jól megtrágyázva megtermi, a több részein a soványság, kövek, kősziklák és haszontalan hegyek miatt meg nem teremnek. A zab is ritka érhetik meg a hideg miatt, egyébféle gabona meg nem terem, négy ökörrel lehet szántani, de kettővel nem.

$-2^{\text {re }}$ Rétyeink nincsenek, hanem a havasokon az erdők közt vannak szénafüveink, mellyeket csak egyszer lehet kaszálni, ahol is egy hold szénafü közönséges terméskor mintegy 3 mását terem, marha legeltetésre alkalmatos a széna.

$-3^{\text {ra }}$ Vásáros hellyünk Udvarhelly, mellynek uttya hágós, löjtös, köves és felettébb alkalmotlan, a bémenetelbe belételik terhes szekérrel 4 óra.

$-4^{\text {re }}$ Marha legeltető hellyünk teheneinknek, jármos ökreinknek és egyéb aprómarháinknak legeltetésére mint kaszálás előtt, mint kaszálás után alkalmatos és elegendö.

$-5^{\text {re }}$ Az edgyik határunkon elegendő a víz, de a másikon szük, úgy a faluban is a nagy hidegek miatt elfogy sokszor a vizünk.

$-6^{\text {ra }}$ Mind tüzre, mind épületre való fánk vagyon, de az úttya felettébb alkalmatlan. Tüzifát fél nap, épületre valót pedig egy egész nap hozhatunk.

$-7^{\text {re }}$ Szőllőnk nincsen. 
$-8^{\text {ra }}$ Makk termő erdőnk közönséges és osztatlan vagyon, mellynek midőn közönséges termése vagyon, a magunk sertésseink meghíznak. Efelett külső sertéseket is két vagy némellykor háromszázat is vehetünk be fizetésért.

$-9^{\text {re }}$ Itten a Fiscus arendájának, tizednek, kilencednek semmi hellye nem volt, mint Székely Földön.

$-10^{\text {re }}$ Gyümöltsös kertyeink, szilvássaink jobb részére vagyon mindnyájunknak, de az elein való hidegek miatt ritkán vehettyük hasznát. Káposztás kertyeink is vannak a faluba.

$-11^{\text {re }}$ Nádunk nincsen, szükségünk sincsen reá.

$-12^{\text {re }}$ A sókereskedésből semmi hasznot nem veszünk, mivel a bánya messze vagyon hozzánk és az úttya is igen rossz.

$-13^{\text {ra }}$ Kiki mesterséget közönségesen gyakorlunk úgy mint kádározást, zsendélly- és deszkacsinálást, mellyel a gabonabéli szükségünket segítsük és a királlyi contributiót fizettyük.

$-14^{\text {re }}$ Vizen való kereskedés semmi nincsen, nem is lehet.

$-15^{\text {re }}$ Közelébb nincsenek jó szöllőhegyek, hanem 6 vagy 7 mértföldre.

$-16^{\text {ra }}$ Sem mész-, sem szénégetéssel nem kereskedünk, mivel kövünk nincsen arra való.

$-17^{\mathrm{re}}$ Ezen communitásnak sem sokadalma, sem kortsomája, sem réttye, sem szántóföldgye nincsen, mellyböl hasznot vehetne.

$-18^{\text {ra }}$ Kenderünk kevés terem, vizünk sincsen áztatásra alkalmatos.

$-19^{\text {re }}$ Malmunk ugyan egy patakon kettő vagyon, de száraz és hideg üdőben nem örölhetünk és ollyankor két órát tartó hellyre kell mennünk őrleni.

\section{$\underline{\text { De maleficiis responsum est in beneficiis }}$}

$5^{\text {re }}$ Itt eddig nem volt szokásba egész és fél sessiók szerént osztani a szántóföldeket és szénafüveket, innen egynek több, másnak kevesebb szántóföldgye és szénafüve vagyon. Egy hold szántóföldbe belé lehet vetni 8 szebeni vékát. A kaszálók iránt a 3-dik kérdésben meg van a felelet.

$6^{\mathrm{ra}} \mathrm{A}$ jobbágyi szolgálatot miként tettük és hány vonómarhával, hasonlóképpen a 3-dik kérdésben meg vagyon a felelet és itt is csak ezt felellyük, a jövetelünk és menetelünk pedig mindenkor imputáltatott, mivel egy fertálly mértföldre mentünk szolgálni.

$7^{\text {re }}$ Mi kilencedet soha sem adtunk s nem is tudunk, hogy ezen nemes vármegyében sohult adtak volna kilencedet vagy más akármelly ajjándékot vagy adózást sem pénzben sem naturában.

$8^{\text {ra }}$ Ezen hellységbe vagyon egy ollyan puszta jobbágysessio, mellyen régentén lakott egy Antal András nevezetủ jobbágy, ennek halála után a ház is a sessioval elpusztult és így redeált Bándi András uramra, halála után a feleségére, Szeredai Veronika asszonyra, aki is most bírja, edgyik szegeletire egy újparaszt egy kis házacskát építet, s azért 1 magyar forint taxát fizet az említett aszszonynak. A több benvaló részét a külső appertinentiáival edgyüt, tudniillik szántóföldekkel és szénafüvekkel edgyüt Berketzi Mátyás, Péter Lőrintz és Gergelly István székely szabademberek taxára bírják. Van 32 esztendeje, hogy el pusztult.

$9^{\text {re }}$ Ezen hellység lakossi mindnyájan szabadszékelek, kivévén a fellyebb említett jobbágyokat, akik mindnyájan örökös jusson biratnak.

[Hitelesítő záradék latinul] 
[Aláírások:] Michael Árvay de Sz. Lélek

exmissus comissarius

et Ladislaus Tamási

exmissus comissarius

[A nyilatkozók, nevük után kereszttel:]

Franciscus Gergelly +

Franciscus Márton +

Petrus Kováts +

Andreas Vas +

Franciscus Albert +

Andreas Dénes +

Joannes Bálint + 


\section{5. július 13. Szentkirály}

\section{Az úrbéri összeírás kilenc kérdőpontjára a szentkirályiak által adott feleletek}

MOL. F. 51.

Ad $1^{\text {um }}$ Nincsen és nemis volt a mü üdőnkben.

Ad $2^{\text {dum }}$ Contractusunk sincsen, hanem a régi bévett szokás szerént szolgáltunk eddig.

Ad $3^{\text {tium }}$ Mü minyájan jobbágyokul eddig az ideig kézi munkával: fészével, faragással, kaszálással, kapálással s aratással és az hogy kévántatott egy héten elég étel mellett két napokon szolgáltunk.

Ad $4^{\text {tum }}$ quo ad beneficia

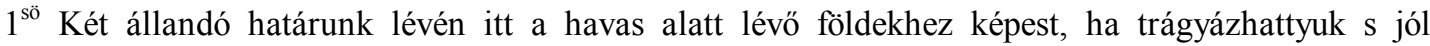
megmívelhettyük, mindenféle gabonát megteremnek a málén kívül, mindazonáltal nem a jó, hanem a középszerü határokhoz hasonlithatók, az holott jól elkészülvén az földek, keverés és vetés idején két ökörrel is lehet szántani, vetni, amelljeknek edgyik része jó, az második csak középszerü termékeny, az harmadik pedig északos, vizes.

$2^{\text {do }}$ A szénarétünk pedig ben a térségben midőn a szárazság vagy az hegyekről egybegyült vizek árja meg nem rontya, jó szénát teremnek s ollykor kétszer is egy esztendőben meg lehet kaszálni és egy hold kaszáló tizenkét mázsa szénát terem meg, bizonyosan nem tudgyuk.

$3^{\text {tio }}$ Udvarhelly hozzánk jövőleg-menőleg négy óráni járóhellj, amelljnek uttya is a sáros üdőn kívül nem alkalmatlan.

$4^{\text {to }}$ Marhalegeltető helljünk elég vagyon.

$5^{\text {to }}$ Itatóhelljünk is bővön vagyon.

$6^{\text {to }}$ Mind tủzi, mind pedig épületre való fánk elég vagyon az havasunkon, mellj nincs messze töllünk $\mathrm{s}$ alkalmatos úttya vagyon.

$7^{\mathrm{mo}}$ Szöllöshelljünk nincsen.

$8^{\circ} \mathrm{Az}$ havasunkon a közönséges heljünkben elég makkos erdőnk vagyon.

$9^{\text {no }}$ Semmiféle dézma- és kilencedadás nincs helljségünkben.

$10^{\mathrm{mo}}$ Gyümölcsös- és veteményeshelljünk magunk szükségére a komlón kívül elég vagyon, komlónk nincsen.

$11^{\mathrm{mo}}$ Nádashelljünk nincsen.

$12^{\mathrm{mo}} \mathrm{Az}$ parajdi sóbányát az ottvaló mulatáson kivül két napok alatt meg lehet járnunk, két mélljföldre lévén hozzánk.

$13^{\text {mo }}$ Udvarhelljt vátig mindenféle mesterember elég vagyon.

$14^{\text {to }}$ Semmiféle hasznunk nincsen az vizeken való járásban, mert ollyan vizünk nincsen.

$15^{\text {to }}$ Négy mélljföldre jó borokat lehet kapni.

$16^{\text {to }}$ Szén- és mészégetöhelljünk sincs.

$17^{\text {to }}$ Itt a falunkban ki-ki árulhat bort, sert, pálinkát, módgya lévén, egyéb beneficiumunk nincsen.

$18^{\text {to }}$ Kenderásztatohelljünk pedig elég vagyon.

$19^{\text {no }}$ A falunk végein kétfelől két csapómalom is vagyon.

$20^{\circ}$ Ecetnek való vadgyümölcs fánk is elég vagyon. 
Maleficia autem inter enumerata beneficia complectuntur

Ad $5^{\text {tum }}$ Nékünk minnyájon jobbágyokul eddig az ideig bizonyos számból álló kiszabott hold szántóföldeink $\mathrm{s}$ kaszálóink nem voltanak, hanem a régi szokás szerént ami kevés birodalmunkban volt abból éltünk, a szénahelljeink pedig ritkán kétszer kaszálhatók s itt is egy hold szántóföldet nyolc szebeni véka búzával vetünk bé.

Ad $6^{\text {tum }}$ Megmondottuk az harmadik kérdésre tett feleletünkben lévő szolgálatunkot.

Ad $7^{\text {mum }}$ A meg mondott szolgálaton kívül semmit egyebet nem adtunk.

Ad $8^{\text {tum }}$ Egy pusztahelljet sem tudunk.

Ad $9^{\text {um }}$ Minket eddig elé úgy szolgáltatott a földesuraság minnyájunkot, mint ősjobbágyokot.

Haec juratorum pagi nomina sequuntur

N. Lörincz Ferenc +

Felső Balás János +

Laszlo András +

Fábián András +

Löriz [!] János mpp +

Gergely István +

Benedek András +

Martinus Miklosj de Fenyed

inclyti comitatus Udvarhelly juratus assessor et in hae urbariali conscriptione exequens magistratualis comissarius

et Franciscus Pálffi de Székely Kocsárd et Szombatfalva

inclyti Comitatus antea sedis siculicalis Udvarhelly juratus assessor et in praesenti urbariali conscriptione exeqvens magistratualis comissarius. 


\section{5. augusztus 13. Tibód}

\section{Az úrbéri összeírás kilenc pontjára a tibódiak által adott feleletek}

MOL. F. 51.

Ad $1^{\text {um }}$ Nincsen urbáriumunk.

Ad $2^{\text {dum }}$ Contractusunk sincsen, hanem a szolgálatot a régi usus szerént tettük eddig.

Ad $3^{\text {tium }}$ Egy héten hol ökörrel, hol pedig más kézi munkával, amint az uraság kévánta két napokon szolgáltunk.

$\underline{\operatorname{Ad} 4^{\text {tum }} \text { quo ad beneficia }}$

$1^{\circ}$ Mindenféle gabonát trágya után, két határunk lévén melyek állandók, megteremnek, hanem két ökörrel nem lehet szántanunk a mü határinkban a melljeknek két része jócska, az harmadik pedig sovány.

$2^{\mathrm{do}}$ A mü határinkban rétek, kaszálóheljek jók nincsenek s ami a mezőkben vannak, azok nem kétszer kaszálandók, külömben jó szénát teremnek de szükön úgy, hogy edgy hold kaszálóhelj négy mázsa szénánál többet nem terem.

$3^{\text {tio }}$ Száraz üdőben jövőleg-menőleg Udvarhelly várossa hozzánk négy óráni járóhellj, az holott holmiből lehetne könyen pénzt szerezni, leginkább pedig fából s gabonából.

$4^{\text {to }}$ Marhalegelö helljünk kevés van, az falunk s határaink kicsin lévén és szoros.

$5^{\text {to }}$ Itatóhelljünk pedig elég van.

$6^{\text {to }}$ Mint épületre, mint pedig tüzre valo erdőnk a Szent Királljiakkal közös lévén, kevés a havason vagyon. Idehaza is az határunkban kevés cziheres Erdőnk vagyon, ahonnan az magunk tüzifánkot megszerezhettyük.

$7^{\mathrm{mo}}$ Szőllőshelljünk nincsen.

$8^{\mathrm{mo}}$ Fenn a havason az közönségesben kevés makkoshelljünk vagyon.

$9^{\text {mo }}$ Nem lévén szokásban a mü vármegyénkben, semmiféle dézma s kilencedbeli adózást nem tettünk, hanem a cantornak s a tisztelendő pater plébánosnak.

$10^{\mathrm{mo}}$ Kevés gyümölcsösünk $\mathrm{s}$ veteményes helljünk benn vagyon a falunkban. Künn pedig nincsen $\mathrm{s}$ komloshelljünk sincsen.

$11^{\mathrm{mo}}$ Nádashelljünk nincsen.

$12^{\mathrm{mo}}$ Depositorium nállunk nincsen, hanem a parajdi bányát, ha megszabadulhat az ember hamar onnan, két napok alatt meg lehet járni, két mélljföld lévén hozzánk.

$13^{\text {tio }}$ Udvarhelljt találtatik mindenféle mesterember.

$14^{\text {to }}$ Hajózásbéli hasznunk semmi sincs.

$15^{\text {to }}$ Négy mélljföldre jó borokat lehet kapni.

$16^{\text {to }}$ Szén- s mészégetö helljünk nincsen.

$17^{\mathrm{mo}}$ Afféle beneficiumaink sincsenek, hanem itthon ki-ki pálinkát, sert, bort ha módgya volna, árulhatna.

$18^{\mathrm{mo}}$ Kenderásztató helljünk pedig elég vagyon. 
$19^{\text {mo }}$ A Falunk mellett vagyon a malom.

$20^{\text {mo }}$ Ecetnek való vadgyümölcsfáink is vannak a mezökben és az erdőkön.

$\underline{\text { Maleficia inter enumerata beneficia complectuntur }}$

Ad $5^{\text {tum }}$ Kiszabott bizonyos számból álló hold szántóföldeink s kaszálóink nem voltanak eddigelé $\mathrm{s}$ a mi kaszálóink pedig egy esztendőben nem kétszer kaszálandók, mivel rétünk nincsen. Egy hold szántoföldben nállunk is nyolcz szebeni vékát szoktak vetni.

Ad $6^{\text {tum }}$ Feljebb az $3^{\text {dik }}$ kérdésre meg feleltük a napi szolgálatot, hanem akinek négy ökre volt néggyel, a kinek pedig két ökre volt, két ökörrel tettük.

Ad $7^{\text {mum }}$ Az megmondott napi szolgálaton kívül egyebet nem adtunk, mivel azon szokás nem volt az vármegyénkben.

Ad $8^{\text {um }}$ Nem tudunk edgy pusztahelljet is.

Ad $9^{\text {um }}$ Ősjobbágyoknak lenni ismértettünk.

[Hitelesítési záradék]

Haec iuratorum nomina sequuntur

Balas Ferencz Hites falusbíró ac mpp

Péter János +

Vas Ferencz +

Martinus Miklosj de Fenyéd

inclyti comitatus Udvarhely juratus assessor et in hac urbariali conscriptione exequens magistratualis commissarius.

et Franciscus Gálffi de Székely Kocsárd et Szombathfalva

inclyti Comitatus antea sedis siculicalis Udvarhelly juratus assessor et in praesenti urbariali conscriptione exequens magistratualis commissarius. 


\section{5. november 28. Ülke}

\section{Az ülkei jobbágyok és zsellérek feleletei az úrbéri összeírás kilenc kérdőpontjára}

MOL. F. 51.

Ad $1^{\text {um }}$ Ezen hellységnek nincsen urbáriuma, mindeddig nem is volt soha.

Ad $2^{\text {dum }}$ Münékünk az jobbágyi és zselléri szolgálatunkról sem urbáriumunk sem pedig contractusunk nincsen; hanem amint az eleink kezdették az jobbágyi szolgálatot, mi is azon módon mindeddig tettük a szolgálatot az földesurainknak.

Ad $3^{\text {ium }}$ Az mi jobbágyi és zselléri szolgálatunk abból állott, hogy a mire kévántattunk, úgymint szántást, vetést, kaszálást etc. az földesurunk számára dolgoztunk minden héten két nap, hol ökörrel, hol pedig gyalogszerben, de emellett semmifélével nem adóztunk mü földesurunknak.

\section{Ad $4^{\text {tum }}$}

$1^{\text {mo }} \mathrm{Az}$ mü hellységünk nem éppen közél vagyon az havashoz, a mellyet ha trágyázhatunk mindenféle gabonát megterem, kivált az fele határunknak, az más részeis határunknak megteremné, ha curálhatnok, de határunknak negyedrészit az nagy hegy miatt nem lehet trágyázni és igy el soványodott erőssen. Itten az mü helységünkben csak néha-néha lehet két ökörrel szántani.

$2^{\text {do }}$ A mi kevés szénafü-hellyeink vadnak, mind künn határainkon, mind benn az falu között, marhalegelni és hizlalni igen jó, de olyan külső szénafü-hellyeink nincsenek, ahol kétszer lehessen kaszálni, az falu között pedig mindenütt lehet kétszer kaszálni edgy esztendőben, az árvíz szénahelyeinket igen ritkán rontya. Itten müköztünk edgy hold szénafü-hellyen megterem jó hat mása széna.

$3^{\text {io }} \mathrm{Az}$ város Udvarhely mühozzánk két órányi járóföld, ahol is amit vihetünk eladni, úgymint fát, gabonát, tejet, vajat, gyümölcsöt etc. mindenféle elkél pénzért, az Utya pedig csak esőss időn alkalmatlanocska.

$4^{\text {to }}$ Az határunk marhalegelésre edgyik elegendő és igen jó; de a másik igen szük, különben jó.

$5^{\text {to }}$ Vizünk az határainkon kivált szározságnak idén igen szük, hogy még más határról is élnek marháink víz dolgából.

$6^{\text {to }}$ Tüzi- és épületfa az falunkhoz közél nincsen, de vagyon havasunk s abból élünk; melynek alkalmatlan az utya és nehezen jutunk hozzá.

$7^{\text {mo }}$ Az mü hellységünkön Szőllőhegy nincsen, de az jó bor földe mitőllünk négy-öt méllyfödnyire esik.

$8^{\text {mo }}$ Münékünk egész falustól itten az faluhoz közél semmiféle makkos erdőnk nincsen, hanem a havason van bükkmakkos erdőnk, mely ritkán fizet.

$9^{\text {mo }}$ Ezen hellységben lakók mindeddig sem felséges királlyunknak, sem pedig földesurainknak semmiféle árendát, vagy dézmát nem adtunk soha.

$10^{\text {mo }}$ Ezen mü hellységünk terem gyümölcsöt is, de nem mindenkor, hanem káposzta és mindenféle kerti vetemény az magunk szükségünkre elegendő s jó terem.

$11^{\mathrm{mo}} \mathrm{Az}$ mü hellységünkön náddal nem tüzelünk, minthogy fát csak kapunk elegendőt.

$12^{\text {mo }}$ Az sóbánya Parajd mühozzánk két napi járóföld ahonnét élünk só dolgából és aki akar $\mathrm{s}$ van módgya benne, kereskedhetik is belölle, mind hogy nincs messze.

$13^{\text {tio }}$ Ha mi mesterember ezen faluban nem találtatik, közél lévén a város Udvarhelly, eleget találunk az magunk szükségünkre. 
$14^{\text {to }}$ Ezen mü hellységünkben nincs olyan nagy follyóvíz, az mellyen kereskedést indithatnánk.

$15^{\text {to }}$ Ezen punctumra az $7^{\text {dik }}$ punctumban meg feleltünk.

$16^{\mathrm{a}}$ Az mü hellyünkön, vagy határunkon sem meszet, sem szenet nem égetünk, mivel nincsen amiböl égessünk; hanem faedényböl lehetne kereskedni, ha mesterségit üznék, egynémellyek szoktak is csinálni fa edényeket, és el is adni.

$17^{\mathrm{mo}}$ Itten ezen hellységnek semmi közönséges jövedelme nincsen, mivel sem sokadalma, sem valami közönséges faluhellye, sem korcsomája nincsen, minthogy félrevaló helly, nincs nagy országúttya, hanem mikor valami kevés makkunk terem.

$18^{\text {vo }}$ Kenderásztatni való tónk az mü hellységünkben igen kevés vagyon.

$19^{\mathrm{mo}} \mathrm{Az}$ mü falunkban malom nincsen, hanem örletni az Küküllöre kell járni, de az úttya nem rossz, és két órára legtovább háromra meg lehet járni.

Ad $5^{\text {tum }}$ Itten a mü hellységünkben edgy hold szántóföldben szoktunk vetni szebeni mértékkel nyolc véka gabonát; nem volt pedig szokásban a sessiókot meghatározni, ki nagyobban, ki küssebben lakik, künn is ki többet, ki kevesebbet bír, mivel mindenkor az helly állandó.

Ad $6^{\text {tum }}$ Én Kando András titulatus Török Pál uram jobbágya és Gabor Peter titulatus Sebestyén Josef uram jobbágya, mü mindketten amint az $3^{\text {dik }}$ punctumra meg mondok, minden héten télben-nyárban, mikor parantsolták, két-két napot szolgáltunk, hol ökörrel, hol gyalogszerben. Én pedig Modi Mihály, titulata Orbány Sigmondné asszony jobbágya minden héten nyárban két nap, télben pedig egy-egy nap szolgáltam kézi szert. Mikor pedig robotára mentünk, mind menetelünköt, mind jövetelünköt a titulatus földesuraink az napszámba belé tudták, ételt adtak nékünk.

Ad $7^{\text {mum }}$ Mü mind közönségesen az földes urunknak sem kilencedet, sem egyébb akármi névvel nevezendő dézmát, vagy ajándékot nem adtunk soha is, minthogy sohasem is kévánták tőllünk, úgy egyebüt is ezen nemes Udvarhely vármegyében, hogy afféle dézmát, vagy akármi ajándékot is adtak volna, soha sem hallottuk.

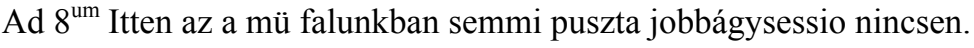

Ad $9^{\text {num }}$ Ezen hellység mind szabad emberböl áll, csak mü egy néhányan vagyunk örökös jobbágyok és zsellérek.

\section{[Hitelesítési záradék]}

Gál Márton mp.

Osvát Mihály m. a. +

Balás Mihály m. a. +

Ambrus Gergelly m. a. +

Péter Márton m. a. +

András Ferencz m. a. +

Demeter János falusbíró m. a. +

Stephanus Boer mpr. nobilis commissarius

et Samuel Szent Györgyi mpr. nobilis commissarius 
A Conscriptio Czirakyana kérdezőbiztosok számára előírt kilenc kérdőpontja

MOL. F. 52.

\section{Elöszer:}

Vallyon és minémű urbárium vagyon ma follyamatban? és az miólta hozatott be?

\section{Másadszor:}

Ahol pedig most semmi urbárium nincsen, a szolgálatok a parasztoktól, az azok eránt költ egyezések szerint vétettnek-e fel? vagy pedig a bévett szokás szerint? az afféle szokás vagy pedig aziránt költ edgyezések mitől fogva kezdőttek és vétettek be? vallyon a mostani contractusok vagy urbáriumok előtt mások nem voltak-e? és ha voltanak azok millyenek voltak? és a mostani kötelezésbéli szokás mikor kezdődött el?

Harmadszor:

Ahol semmi urbárium vagy egyezés nincsen, a bévett szokás szerint való szolgálatok miben állanak? és azok mikor s mi móddal hozattak be?

Negyedszer:

Edgyenként minden hellységnek minémü hasznai? s viszont micsoda terhei vadnak?

\section{Ötödszer:}

Egy egész telken lakó collonusnak hány és millyen szántóföldgyei és kaszállóréttyei vadnak? és mindenik hold föld hány bécsi mérőjü és vallyon a kaszálló réteken lehet-e sarjút is kaszálni?

\section{Hatodszor:}

Eddigelé külön-külön minden szolgáló ember hány napi szolgálatot tett? és azokot hány jármas marhákkal tette? továbbá az ők menetelek és jövetelek szolgálattyokban feltudattanak-e vagy sem?

\section{Hetedszer:}

Vallyon az urbarialis tized (:dézma:) vagy ahol eddigelé szokásban volt a Kilenced miólta és nevezet szerint mikből adatott? és vallyon ezen tized vagy kilenced adása ennek azon vármegye, szék vagy vidékben lévö más uradalmokban szokásban van-e? efelett a parasztok ezenkívül más daciák (:tartozásbéli adományok:) színe alatt eddigelé földesuroknak esztendőnként mit adtanak? és nevezetesen az amit a földesúr ez alatt a szín alatt készpénzül vagy naturában tőllök felvett miből állott?

\section{Nyolcadszor:}

Minden hellységben hány pusztatelkek vadnak? azok miólta? mi okból? és ki által használtatnak?

Kilencedszer:

Vallyon a szolgáló emberek az erdőlést úgy használhattyák-é, hogy abból kereskedhessenek is? és továbba az uraságnak a hellység határán kívül lévő erdejét használhattyák-e? és végre a telkeknek szabad eladása és vevése szokásban van-e? 
9.

1820. június 26., Oroszhegy

Az oroszhegyiek válaszai a Cziráky-összeírás kérdőpontjaira

MOL. F. 52. Udvarhelyszék. Oroszhegy. V. köt. 411-448. lap

Ezen follyo $1820^{\mathrm{ik}}$ esztendőben júniusnak $26^{\mathrm{dik}}$ napján follytataték az urbarialis conscriptio itten nemes Udvarhelly székben a fartzádi járásban Oroszhegyben az Agilis falusbíró Gergelly Josef lakóházánál exequens magistratualis Szent Léleki Pakot Elek és Kis Kedei ifj. Imreh György conscriptorok által, a bébíró possessor urak meg nem jelenvén, a falunak elöljárói és a commetaneusok előtt és által

Commetaneusoknak béesketvén

A székelek részéröl

1 - Gergelly Joseff falusbíro

2 - Gergelly Ferentz

3 - Tamás Ferentz

4 - Peter István

5 - Marton Antal

6 - Major István

7 - Dénes Péter

A sellérek részéről

A sellérek a havason messzüre lévén majorság és pakulárság follytatására, a feleségeiket pedig bé nem eskethetven substituáltuk hellyekben a libertinusokot.

8 - Nagy János meg halálozott

9 - Nagy András

10 - Páll Antal

Kiket is az esküvés formája szerint meg esketvén, a következendő urbarialis vallatópontokot terjesztettük eleikben.

[A kérdöpontra adott feleletek a következők:]

Elöszer

Itten urbárium soha nem volt és hirit is mostanig nem hallottuk.

Másadszor

Itten nem hogy urbárium szerint való szolgálat volna, de még szokás vagy contractus szerint való szolgálat is nincsen, mivel a bébíró possessor uraknak jószágát vagy a benne lakó emberek vagy mi szabad székellyek pénzzel vagy más naturabeli praestatiokért arendállyuk ki. 


\section{Harmadszor}

Az előbbeni kérdésre amint megmondottuk, hogy itt semmiféle szolgálat nincsen, hanem a bébíró possessor urak a jószágokot arendára birassák azért erre a kérdésre ezt felellyük

\section{Negyedszer}

Következnek a beneficiumok illy renddel

a - Vagyon két fordulló határunk köves, oldalos helljeken fekvő és csak négy ökörrel mivelhető s a legjobb mívelés után is a határunknak egy harmadrésziben ha vetünk egy véka őszgabonát, megterem utánna két kalongya, amelly ereszt 3 vékát, a más két résziben csak zabot vetünk $\mathrm{s}$ ez is hasonlóképpen terem.

b - Mindenféle marhatartásra megkivántató szénánk terem, és a ki trágyázza a kaszálóit annak elég van, de aki nem trágyázza a sok hellyen is kevés gyül és csak a faluban s a falu körül lévő kertekben lehet sarjut csinálni.

c - A város Udvarhelly ide 3 óra járás distantia, ahová minden míveinket és amink van eladni való, mint tőtőre járható alkalmatos úton visszük eladni.

d - Legelöhellyünk jó és böven van mindenfele marháinknak.

e - Itatóhellyeink jók és alkalmatosok vadnak.

f - Mind épületre, mind tüzre meg kivántató fánk egy mérföldni distantiára elég van, közelebb a falu mellett is volna, de ezt a makkolásra a szegény marha nélkül valo emberek számára és hogy ha valami marhadög lenne, hogy akkor közelebb kaphassuk avégre erős tilalomban tartunk.

g - Szőllőhegy sem itt sem közél nincsen.

h - Mikor a makknak termése van, amelly igen ritkán terem, akkor a falu sertéssei meghíznak és ha a szegény embernek nem volna, szabad fizetésért a maga számára be hozni.

i - Semmiféle dézma itt nincs szokásban.

k - A határunkon nincsenek semmi gyümölcsösseink, a vadgyümöltsfákon kívül, mellyeket ecet csinálására használunk ha nem a falunkban házunk mellett kinek-kinek vagyon egy kevés gyümölcstermö fáink.

1 - Nádtermő hellyünk nincsen.

m - A Sóakna ide 2 mérföld, de nem kereskedünk velle.

\section{Pénzt pedig kapunk}

A havasunkból az benne lévö fenyőfákból, boronafát, zsendellyt, lécet, szőllőkarót csinálunk. Deszkát a fürészeinken vágunk, mesterembereink kádat, csebret, kártyát, eceteshordót csinálnak és ezeket a szomszéd havasatlan székekben, vármegyékben visszük eladni és az ezekböl béjövő nyereségből pótollyuk határunk terméketlenségit, de segíttünk még magunkon a juh, kecske, ménes és szarvasmarha tartással.

n - Hammuzsír-főző fabrika van de bizonytalan üdőig áll.

o - Hajókázható vizünk nincs kezünk ügyibe.

p - Szőllőhellyünk sem itt, sem közel nincs. ${ }^{162}$

\footnotetext{
${ }^{162}$ A jegyzőkönyvben az egész p) pont áthúzva.
} 
q - Sem meszet, sem szenet nem égetünk.

r - Állandó közjövedelmünk nincsen, hanem mikor a falunknak nagy szüksége érkezik, akkor a hammuzsírnak való fákot el adjuk, ollyan esetben a legelöhellyünkből is egy-egy darabot arendába kiadunk.

s - Alkalmatos kenderásztato hellyek vadnak.

t - Itten vagyon ött malom. Az egyik két kövü, Gergelly Ferentzé és Jósefé, a másik Kováts Ferentzé testvéreivel edgyütt, a harmadik Vas Andrásé és Josefé, a negyedik Tamás Ferentzé, az ötödik Márton Antale, mely malmok a szárazságban, amikor nem forognak is, a Zatalaki Küküllőn lévö malmok két óra járó distantiára vadnak, ahol commode őrölhetünk.

u - Az erdők nincsenek felosztva. Pascumotis senki sem arendál.

x - Bolt nincs, meszárszék, kortsomálás, pálinkafőzés köz.

y - Mesteremberek kovács 1., szőcs 3, csizmadia 1, kádár 10 vagyon.

z - Köépületre való kő vagyon.

A maleficiumokra a beneficiumok soraiban meg feleltünk.

Ötödszer

Közönségesen is megtudnok mondani, hogy hány sellér van itten, mennyi férö földjük van a mi mértékünkkel, de mi a hold, mi a bécsi mérő, azt nem tudjuk, azért a conscriptióba a mi mértékünkel fel is fogjuk adni. Sarjú itt terem a falu közöt lévö kertekben.

\section{Hatodszor}

Amint fennebb is megmondottuk, itten szolgálatra jószágot a sellérek nem bírnak, hanem ki-ki hogy megegyezhetik taxára esztendönként földesurával aszerint fizet. u. m. méltóságos liber báró Henter Antal úr őnagysága 3 colonnussai 40 Rforintot, tekintetes Szombathfalvi Jánosné tekintetes Török Maria asszony 1 colonnussa, 2 inquilinusa 15 Rforintot, Jaroban vadban Tekintetes Matyus Josef deserta sessiojáért Jaroban 10 Rforintot. A Bandi successorok a többi el adván tekintetes Hegyesi István úrnak fizetnek 18 Rft. És tekintetes Salamon N. úrnak 1 Rforintot s egy véka szilvát, mikor pedig szilva nem terem 2 Rforintot, mindöszve az egész faluban esztendőre arendát fizetnek 82 Rforintot és 3 krt.

\section{Hetedszer}

Semmiféle dézma nincs szokásban.

\section{Nyoltzadszor}

Itten a faluban hány pusztatelkek vadnak, a conscriptioban fel fogjuk adni az mellyekröl az ház el posztult s úgy lettek puszták s most a földesuraknak fizetnek érte taxát.

\section{Kilentzedszer}

Az itten bébíró possessor urak emberei minden erdőbéli beneficiumot úgy használnak, mint mủ székelek, mivel itt az erdő az élet tartására legnagyobb eszköz s hogy pedig másuva mennyenek erdőlni, arra nincs szükség. - A telkek eladása nem csak hogy nem szabad, sőt meg is van tiltva. 
Jegyzés

A mi a határ minémüségit, termékenységit nézi, amint a falunak elöljárói a Commetaneusokkal a beneficiumok A alatti positiójában megdisputálták, megállították úgy tetszik nékünk is $\mathrm{s}$ az is a vélekedésünk, hogy mind havas torkában lévö határ és csak igen kicsin része a határnak is gabonatermő, annak egyharmad részit közepesnek, a más két részit alábbvalónak lehet venni.

Hogy ezen vallomások általunk lelkiesméretünk és hitünk szerint anyai magyar nyelven felvétettek, felolvastattak és a fentirt béeskütt bírák és lakosok részszerint kezek írásával, részszerint akik írni nem tudnak kezek keresztvonásával, minthogy a hellységnek pecséttye nem volt, meg erösítettek - Usualis pecsétünk és subscriptiónk által recognoscállyuk. Költ a fentirt hellyen, esztendőben és napon -

\section{Gergelj Ferentz mpp}

Gergelj Joseff +

Tamás Ferentz +

Péter István +

Márton Antal mpp

Major István mpp

Dénes Péter +

Nagy András +

Páll Antal +

Szt. Léleki Pakot Elek mppja [pecsét]

és KKedei Ifj. Imreh György mppja [pecsét]

Exequens urbarialis conscriptorok 
10.

\section{0. július 29. Szentkirály}

\section{A szentkirályi úrbéresek feleletei a Cziráky-féle összeírás kilenc kérdőpontjára}

MOL. F. 52.

$\operatorname{Ad~N}^{\text {ro } 2113 . ~} 821$

Ezen follyó $1820^{\text {ik }}$ esztendőben júliusnak $29^{\text {ik }}$ napján follytatódik az urbariális conscriptió itten nemes Udvarhelly székben a fartzádi járásban Szent Királlyon az agilis felső Balás Antal házánál exequens magistratuális Szent Léleki Pakot Elek és Kis Kedei ifjabb Imreh György conscriptorok által, tekintetes Sebestyén Moses és Székelly Ferentz possessor urak s más faluban lakó székelly emberek jelenlétekben.

Commetaneusoknak felvévén

A székelek részéröl

1 Balás Antal

2 Üdösebb Balás János

3 Lörintz István

4 Lörintz Joseff

5 Bodo István

6 Felső László István

A sellérek részéről

7 Tiboldi István, méltóságos Ugron Ferentz úr embere

8 Sima Ferentz $\{$ mindketten tekintetes Székelly Ferentz úr emberei

9 Sima Mihaly

10 Tiboldi Márton méltóságos Ugron János úr embere

Kiket is az esküvés formája szerint megesketvén, a következö urbariális vallatópontokot terjesztettük eleikbe:

[A kérdőpontokra adott feleletek a következők:]

(1) Itten hogy urbárium lett volna, nem hallottuk mostanig azt sem tudtuk mit tészen azon szó urbárium.

(2) Itten se nem urbariális se nem contractuális szolgálat módgya van; hanem szokás szerint tésszük a szolgálatott, amelly szokás még az apáinkról maradott reánk, és hogy más Szolgálattétel módgya lett volna, nem is hallottuk.

(3) A mi szokás szerint való szolgálatunk áll - az egy kézi és marhával valo dologtételben hetenként étel adás mellett, és mikor kezdődött arra nem emlékezünk, egyebet ennél nem adunk. 
(4) Következnek a beneficiumok illy rendel:

a - Hegyek közt fekvő agyagos határunkot két fordullóban használjuk s inkább négy ökörrel mint kettővel mívelhettyük, vetünk belé rosot, árpát és zabot és ha összel egy véka rosot elvetünk, megterem a határunknak fele résziben utánna 2 kalongya, amelly megereszt 3 vékát, a más feliben csak zabot szoktunk vetni s az is hasonlólag egy véka után terem két kalongya, melly két kalongya 3 vékát ereszt.

b - Mindenféle marhának tartására, meghízlalására alkalmatos szénánk terem oldalos havasos egyszer kaszálható hellyeinken középszerü mértékben, mikor pedig jó termése van a fünek, akkor bőv mértékben vagyon.

c - Udvarhelly várossa ide 3 fertály mérföld ahová is félórányi distantiáig alkalmatos úton, az után pedig mindenütt csinált töltött úton a természetnek minden jovait és míveinket visszük eladni, ahol commode distrahállyuk is.

d - Mindenféle marháinknak, sertéseinknek, ménesünknek legeltetésére megkívántato pascuumunk középszerü mértékben vagyon.

e - Itatóhellyeink jók és bőven vadnak.

f - Tüzelésre megkívántató fánk elég van, de fenyőfánk a havasunkon nem lévén, a szomszéd havasos faluktól olcsón kapunk s hozunk, mivel bükkfából építteni nem szoktunk, vagyon csak ugyan csereerdőnk talpnak és eszköznek való, mellyet tilalomban tartunk.

g - Sem itt, sem közel szőllöhegy nincsen.

h - Mikor a makknak termése van, akkor a sertésseink meghíznak, de igen ritkán szokott teremni és minyájan osztatlanul közre használlyuk.

i - Semmi féle dézma nincs szokásban.

k - Különös gyümölcsös kerteink a határon nincsenek vadgyümölcsfákon kívöl, mellyeket ecetcsinállásra használunk, hanem kinek-kinek a faluban a háza mellett szükségére megkívántató alma, körtvély, szilva gyümölcstermő fáink vagynak, úgy a kertek mellett is komló terem.

1 - Nádtermő hellyünk nincsen.

m - A sóakna ide két mérföld és amég így meg nem drágult a só, addig inkább kereskedhettünk velle, de most a házunk szükségére valót is alig tudgyuk kiszerezni.

\section{Pénzt pedig kapunk}

Udvarhelly várossában ki-ki szabadon hordja a tűzifát, a feleségeink tejet, tojást, vajat, tyúkot, csirkét és veteményt hordnak eladni, emellett, most a havassunk el levén posztulva, a szomszéd havasos faluktól vagy pénzzel, vagy a nyereségből fordulandó gabonával fenyőt arendálunk ki, és abból boronafát, edényeket, szőllőkarót és más egyébb míveket csinálunk s hordjuk eladni és az ezekből jövő nyereségből segíttünk a határunk terméketlenségin.

n - Semmiféle fábrika sem itt, sem közél nincs.

o - Hajókáztató vizünk itt a határon nincsen, hanem a szomszéd falu határán folly a Küköllő és ha havasunk arravaló volna, kereskedhetnénk rajta.

p - Kikötőhelyünk sem itt sem közel nincsen. ${ }^{163}$

q - Sem meszet sem szenet nem égetünk.

r - Közjövedelmünk semmi sincsen.

s - Kenderásztató hellyeink alkalmatosok vadnak.

${ }^{163}$ Az eredeti jegyzőkönyvben a p) pontra adott felelet utólag kihúzva. 
t - Itt a falu között vagyon két kétkövü malom, az edgyik tekintetes Sebestyén Moses úré több részesseivel edgyütt, a másik Balás Antalé több atyafiaival edgyütt.

u - Mesterembereink vadnak Szöts 2, kádár 4, szabó 1, kovács 1, marhaorvos 2, kik is a publicumnak nagy hasznára vadnak.

x - Bolt nints, mészárszék, kortsomálás, pálinkafőzés köz.

y - Épületre való kő van.

\section{A maleficiumokra a beneficiumok soraiban meg feleltünk.}

(5) Közönségesen meg mondani nem tudjuk, hanem a conscriptióban kinek-kinek neve után felfogjuk adni úgy azt is, hogy a mi mértékönkkel mennyi férőüek, mivel mi légyen a hold, mi a bécsi mérő, azt sem tudjuk. Sarjú pedig itt nem terem.

(6) Tekintetes Székelly Ferentz úr 4 colonusai egész esztendő alatt ökörrel 416 napot és ha tenyérrel kívántatik akkor is ennyit. Tekintetes Sebestyén Moses úr 3 collonusai tenyérrel szolgálnak 208 napot. Tekintetes Sebestyén Péter úr 1 sellére 52 napot. Tekintetes Török Ferentz úr 1 Collonusa 104 napot. Méltóságos Ugron Ferentz Ur 1 collonusa 104 napot. Méltóságos Ugron János úr 1 collonusa 104 napot. Tekintetes Dakó Sandor úr 1 collonussa 104 napot. Tekintetes néhai Lukatsfi Elek úr árvái collonusa árendát fizetnek 14 Rénes forintot és így mindöszve a hellységbeli szolgálóemberek ökörrel 624 napot, tenyérrel 468 napot, fizetnek 14 Rf. árendát, a szolgálatra való menés-jövés nem érdemel consideratiót.

(7) Mü semmiféle dézmát sem adunk és azt semmivel is nem váltyuk meg.

(8) A faluban egy pusztatelek sincs másnak, hanem Sebestyén Moses úrnak égy, mellyet maga használ.

(9) Az erdőlést minden szolgálóember ahogy teccik úgy mint mü székelly emberek használlyák és kereskednek velle. - A telkek eladása nemcsak hogy nem szabad, sőt meg is van tiltva.

Jegyzés

Ami a határ münemüségét és a termékenységit nézi, amint a possessor urak és más falusiak a commetaneusokkal a beneficiumok A alatti positiójában meg disputálták és meg állították, azt gondollyuk mü is, amint kitanolhattuk, hogy a Szent Királlyi határnak a felit a havas alatt lévő határokhoz mértékelve közepesnek, a más felit rosszabbnak lehet venni.

\section{Balás Antal mp}

Idösb Balás János +

Lörintz István +

Lörintz Josef +

Bodo István +

Felső László István +

Tibodi István +

Sima Ferentz +

Sima Mihálly +

Tibodi Márton +

Sz. Léleki Pakot Elek mp [gyürüs pecsét]

és K. Kedei Ifj. Imreh György mp [gyürüs pecsét]

Exequens urbarialis conscriptorok 
11.

1820. június 8. Tibód

A tibódi úrbéresek feleletei az úrbéri összeírás kilenc kérdőpontjára

MOL. F. 52. V. könyv. 161-192 lap.

Ad. Nr. 2113. 821.

Ezen follyó $1820^{\mathrm{ik}}$ esztendőben júniusnak $8^{\mathrm{ik}}$ napján follytatatik az urbarialis conscriptio itten nemes anya Udvarhelly székben a Fartzádi járásban Tibodban a méltóságos Ugron Gáspár úr curiájában levő Házánál tekintetes Török Sándor és Ferentz méltóságos Ugron Gáspár possessor urak személlyes jelenlétekben, ugy méltóságos Mara Joseff úr személlyese, Ferentzi Antal uram és KKedei ifj. Imreh György conscriptorok által a falusiak jelenlétekben Szent Léleki Pakot Elek.

Commetaneusoknak bé esketvén

A székelek részéröl

$1^{\circ}$ Balás Ferentz

2 Balás János

3 Magdo András

A sellérek részéről

4 ifj. Ferentzi János falusbiró titulatus Székelly Ferentz úr embere

5 András János titulatus Török Ferentz úr embere

6 Kovats Ferentz titulatus Török Sándor úr embere

7 Laszlo Ferentz méltóságos Mara Joseff úr embere

8 Horváth János tekintetes Török Miklós úr embere

9 Beretzki János titulatus Sebestyén Moses úr embere

10 Ferentzi Joseff méltóságos Ugron Gaspar úr embere

Kiket is az esküvés formája szerint megesketvén a következendő urbarialis vallato pontokot terjesztettük eleikben:

[A kérdőpontokra adott feleletek a következők:]

Előszer

Itten urbárium nincsen és hogy lett volna is mostanig semmi hírit sem hallottuk.

Másodszor

Amint fennebb is meg mondok itten urbárium nincsen, azért ahogy apáink vagy nagyatyáink a földesuraink eleivel ahogy meg egyezhettek mü is azon szokásá vált egyezés mellett tészszük a szolgálatot. 


\section{Harmadszor}

Ami szokás mellett téendö szolgálatunk áll, akinek marhája van marhával, akinek nincs tenyérrel való dologtételben (:tehetségünkhez képest:) Hetenként ételadás mellett és ezen kívül semmi dáciákot praestatiókot nem adunk, nem tészünk.

\section{Negyedszer}

Következnek a beneficiumok illy rendel

a - Határunkot két fordullóban használlyuk, és két ökörrel is mivelhetők szántóföldgyeink s ha a határunknak fele résziben ha vetünk egy véka öszgabonát jól mívelve megterem utánna 4 kalongya amelly annyi vékát ereszt, a más résziben egy véka után megterem két kalongya, amelly két vékát ereszt. Termesztünk pedig a határunkon búzát, kétszerest, rosot, árpát, zabot.

b - Mindenféle marhatartásra megkévántató szénánk egyszer kaszálható, hellyeinken elegedendő terem. A határunkon keresztülfollyó Busnyák nevezetű patak mellett egynéhányunknak, akiknek ott kaszállója van, amikor kiárad kárt tészen, de akkor is nem posztíttya el mindenkor.

c - Mindenféle marhatartásra megkívántató legelőnk itt a határon is középszerü mértékben vagyon, de emellett a földesuraink a havasos falukban mind bébírók és ha tettzik, oda is fizetés nélkül el hajthassuk.

d - Itatóhellyeink jók és bőven vadnak.

e - Az erdők fel lévén osztva takarékosan a közrehagyot erdőből és az urunkébol is engedelemmel tüzre kapunk. Épületre valót pedig az urunk bé bírása után csakugyan ingyen kapunk.

f - Szőllőhegy sem itt, sem közel nincsen.

g - Amikor a makknak termése van, akkor a házunk szükségére való sertések meghíznak, a többi kitelelnek.

h - Semmiféle dézma nincs szokásban.

i - Udvarhelly várossa ide egy mérföld, ahová fél órányi distantiáig nem töltött úton, de azután mindenütt csinált úton visszük a természetnek minden jovait.

k - Különös gyümöltsös kerteink nincsenek, hanem a faluban a házunk mellett lévö kertekben alma-, körtövélly-, szilvatermö fáink vadnak, amellyeknek mikor jó termése van, akkor a szükségen fellyül el is adhatunk. - Komló a kertek mellett terem.

1 - Nádtermő hellyünk nincsen.

m - A sóakna ide 1 1/2 mérföld ahová is egy fertálly distantiáig nem csinált úton, azután pedig töltött úton menyünk és amíg így meg nem drágult, addig kereskedtünk is velle, de azután házunk szükségére is alig tudunk szerezni.

\section{Pénzt pedig kapunk}

A naturaléknak Udvarhellyt valo eladásából, napszámoskodásból, pálinkafőzésből, korcsomálásból.

n - Fabrika sem itten, sem közel nincsen.

o - A Küköllő fél orai distantiára van és kereskedhetnénk rajta, de nem szoktunk.

p - Kikötöhellyünk sem itt, sem közél nincsen.

q - Sem meszet, sem szenet nem égetünk.

r - Semmi közjövedelmünk nincs.

s - Alkalmatos kenderásztató hellyünk van. 
t - Itt a falu között follyó patakon vagyon tekintetes Török Ferentz úrnak egy kétkövü malma, amelly mikor nem forogna is, a Küköllőn lévő malmok fél órányi distantiára vadnak, ahol commode őrölhetünk.

u - Az erdő fel van osztva pascumot senki nem arendál.

$\mathrm{x}$ - Bolt nincs. Mesterembereink nincsenek.

y - Köépületre való kö, füveny van.

z - Mészárszék, kortsomárlás, pálinkafözés mindennek szabad.

A maleficiumokra a beneficiumok soraiban meg feleltünk.

Ötödszer

Közönségesen meg mondani nem tudgyuk, hogy hány szántó- és kaszállóhellyeink vadnak, hanem a conscriptióban kinek-kinek a neve után fel fogjuk adni, hogy hány darab szántó- és kaszállóhellye van és azok a mértékünkel mennyi férők, mivel mi a hold, mi a bécsi mérő, azt sem tudjuk. Sarjút pedig nem lehet csinálni.

\section{Hatodszor}

Tekintetes Török Ferentz úr 1 collonussa és 4 inquilinussa 416 napokot egész esztendö alatt, méltóságos Mara Joseff úr 2 collonusai 208 napokot, méltóságos Ugron Gáspár úr inquilinnussa 104 napokot, tekintetes Török Miklós úr 1 collonussa 104 napokot, tekintetes Török Sándor úr 1 collonussa 104 napokot, tekintetes Székelly Ferentz úr 1 collonusa 104 napokot, tekintetes Sebestyén Moses úr 1 inquilinussa 52 napokot, mindöszve ezen faluban a collonusok és inquilinusok szolgálnak ételadás mellett 1092 napot, akinek ökre van ökörrel, akinek nincs tenyérrel, ahogy földesurának tettszik, csak avval a külömbséggel hogy ökörrel csak délig szolgálnak. - A jövés-menés hogy fel vétessék nem érdemli meg, mivel vagy itt vagy a szomszéd falu határán tésszük a szolgálatot.

\section{Hetedszer}

Mü se dézmát, se nonát nem adunk és azt semmivel is nem váltyuk meg.

Nyolcadszor

Itten pusztatelkek nincsenek.

\section{Kilencedszer}

Amint fellyebb is meg mondottuk, itt az erdők fel vadnak osztva, azért fával másunnan is urunk bébírása után, hogy máshonnan kereskedni fát hordjunk, nem fizeti meg a messzeség mian. A telkek eladása nem hogy szabad volna, sőt meg van tiltva nagyon.

\section{Jegyzés}

Ami a határ termékenységit, minémüségit illeti, amint a possessor urak a commetaneusokkal megdisputálták, megállították a beneficiumok $\mathrm{A}$ alatti positiójában, onnan a mi vélekedésünk az, hogy a határnak felit közepesnek, a más felit alábbvalónak lehet venni.

Hogy ezen vallomások általunk lelkiesméretünk és hitünk szerént anyai magyar nyelven feltétettek, felolvastattak és a fennírt béesküdt bírák és lakosok által, egyik is írni nem tudván, miért hogy a hellységnek petséttye nem volt, kezek kereszt vonásokkal meg erösítettek - usualis pecsétünk és subscriptiónk által recognoscállyuk - költ a fennírt helyen, esztendöben és napon. 
Balás Ferentz +

Balás János +

Magdo András +

Ferentzi János +

András János +

Kováts Ferentz +

Laszlo Ferentz +

Horváth János +

Beretzki János +

Ferentzi Josef +

Sz. Léleki Pakot Elek mp. [gyürüs pecsét]

és KKedei Ifj. Imreh György mp. [gyürüs pecsét]

exequens urbarialis conscriptorok 
12.

1820. június 22. Ülke

Az ülkei úrbéresek feleletei az úrbéri összeírás kilenc kérdőpontjára

MOL. F. 52. 118. kötet. 449-455. lap

Ad. No. 2123. 821.

Ezen follyo $1820^{\text {dik }}$ esztendőben júniusnak $22^{\text {ik }}$ napjain follytatatik az urbariális conscriptió itten nemes Udvarhelly székben a fartzádi járásban Ülkében a tekintetes Orbán Antal úr curiájában lévö házánál exequens magistratuális Szent Léleki Pakot Elek és Kis Kedei ifj. Imreh György conscriptorok által; possessor csak ugyan titulatus Orbán Antal úr és a falu elöljárói jelenlétekben.

Commetaneusoknak fel vévén

A székelek részéről

1 Amburus János falusbíró

2 Amburus Ferentz

3 Balás András

4 Vass Elek

5 Vass András

A sellérek részéröl

6 Modi János, titulatus Orbán Antal úr embere

7 Vass Ferentz méltóságos Mara Joseff úr embere

Kiket is az esküvés formája szerint megesketvén, a következő urbariális vallatópontokat terjesztettük eleikben.

[A kérdőpontokra adott feleletek a következök:]

Elöszer

Itten urbárium nincsen és hogy lett volna is mostanig semmi hírit nem hallottuk.

Másadszor

Urbárium itten nem lévén, szokás mellett tésszük a szolgálatot, amelly szokás még atyáinktól maradott réánk, és hogy valami más különös szolgálat módgya lett volna ennél, nem is hallottuk.

Harmadszor

Szokás mellett praestalandó szolgálatunk áll hetenként ökörrel és tenyérrel való dologtételben étel adás mellett, s ennél egyebet semmit is nem adunk. 
Negyedszer

Következnek a beneficiumok illy renddel

a - Oldalos hellyeken fekvő határunkot két fordullóban használljuk és ha vetünk belé, jól mívelve, egy véka őszgabonát, megterem utanna 3 kalongya. Kalongyája megereszt $11 / 2$ vékát, a rosszában pedig zabot vetünk amely hasonloképpen terem és ereszt. Határunkot pedig két ökörrel is mivelhettyük, termesztünk is mindenféle gabonát.

b - Mindenféle marhának megkívántató széna egyszer kaszálhato hellyeinken, kivévén a falu között körül lévő tanorokokot, ahol sarjút is lehet kaszálni, középszerü mértékben terem. A falu határán keresztülfollyó patak kárt is tészen ritkán a szénarétekben.

c - Udvarhelly várossa ide fél mélyföld distantia, ahova egy fertálly óráni distantiára nem töltött úton, azután pedig mindenütt csinált uton menyünk és ami eladni valónk van, visszük.

d - Közönséges pascuumunk vagyon jó.

d [!] - Itatóhellyeink jók vadnak.

e - Tüzre meg kívántató fánk is itten a falu határán elegedendő nincsen, hanem a havas ide egy mértföld, ahol mind tüzre, mind épületre való fát eleget kapunk s hozunk járható úton.

f - Szőllőhegy nincs.

g - Mikor jó termése van a makknak mind most, akkor a falu sertéssei meghíznak.

h - Semmiféle dézmát itt senki nem ad.

i - Különös gyümöltsös kerteink nincsenek; hanem a faluban házunk mellett lévő veteményes kerteinkben gyümölcstermö fáink vannak, ezen kivül ecetcsinálásra vadfáink a mezőn elegendök vadnak.

k - Se nád, se komlótermő hellyeink nincsenek.

1 - Sódepositorium nincsen, hanem a sóbánya ide más[fél] mérföld és meddig a só így meg nem drágult, a pénz is így meg nem szükült, addig kereskedtünk a sóval. De már most házunk szükségére valót is alig tudunk szerezni.

\section{$\underline{\text { Pénzt pedig kapunk }}$}

Udvarhelly várossa ide egy óra járó distantia lévén, minden naturalékot és ha teccik minden nap tủzre való fát hozhatunk be eladni. Palinka fözésböl Botskor arulasbol és Fenyö Borona fánk el adásából.

m - Fabrika nincsen.

n - A Küköllő egy óra járó distantia és ha kereskedni szoktunk volna, tutajjal kereskedhetnénk, fenyőnk elég lévén, de minthogy nem szoktunk, azért nem is kereskedünk.

o - Kikötöhelly nincs. ${ }^{164}$

p - Se meszet, se szenet nem égetünk.

q - Közjövedelmünk nincs.

$\mathrm{r}$ - Kenderásztató hellyeink vadnak.

s - Malom itten nincsen, hanem Szent Tamáson, amelly falu a millyenkkel egyben ragadva, vagyon egy patakon lévő malom, de ez is szárazságban nem forog, hanem a Küköllőn lévő malmok ide egy óra járó distantiára vadnak, ahol commode örölhetünk mindenkor.

t - Bolt nincs, mészárszék kortsomáláskor.

u - Mesterembereink nincsenek.

$\mathrm{x}$ - Épületre való kő van.

${ }^{164}$ Az eredeti jegyzőkönyvben az o) pontra adott felelet utólag kihúzva. 


\section{A maleficiumokra a beneficiumok soraiban meg feleltünk.}

\section{Ötödszer}

Közönségesen is meg tudnok mondani, hogy kinek-kinek hány darab szánto- és kaszállóhellye van és azok a mi mértékünkkel mennyi férők (:de mi légyen a bécsi mérő és hold, azt nem tudgyuk:) amint a conscriptióban kinek-kinek neve után megteccik. Sarjút pedig itt a tanorokokon kivül nem lehet csinálni.

\section{Hatodszor}

A jószág jövedelmihez képest és a benne lakó emberek tehettségihez képest, amint a conscriptióban ki-ki a maga neve után fel fogja adni, hogy hány napot szolgál. Akinek pedig négy ökre van néggyel, akinek kettő van kettövel, akinek egy sincs, tenyérrel tészi a szolgálatot, a jövés-menés nem érdemli hogy fel vétessék, mivel vagy itt a faluban, vagy félóra járó distantiára tesszük a szolgálatot. - Mindöszve esztendő alatt titulatus Orbán Antal úr 1 colonussa 76 napot, méltóságos Mara Jóseff úr 1 Colonnussa 104 napot, méltóságos Toldalagi Lászlóné őnagyságának 25 Rénes forint árendát fizetnek mindöszve az egész faluban ételadás mellett. A collonusok, inquilinusok esztendő alatt 180 napot fizetnek, 25 Rénes forint taxát, egyebet semmit sem.

\section{Hetedszer}

Itten se dézma se nona adása nincsen szokásban és azt semmivel is a sellérek nem váltották meg.

\section{Nyolcadszor}

Itten a faluban gróf Korda Annának vagyon egy emberi emlékezettől fogva mindég puszta telke, mellyet a külsőivel edgyütt árendára bírat.

\section{Kilencedszer}

A falu határán, amint fellyebb is megmondottuk, éppen elegedendő tüzifa nincsen, hanem a havason elegedendő van, ahonnét mind tüzelésre, mind kereskedésre szabadon hordhassák a sellérek is és hogy másuva mennyenek erdőlni urok bébírása után is nincs szükség reá, de ha teccenék, senki sem ellenezné. A telkek eladása és vevése nem csak hogy szabad ne volna, sőt keményen meg is van tiltva.

\section{Jegyzés}

Ami a határ termékenységit és minémüségit illeti amint a beneficiumok A alatti positiójában a commetaneusok a falusiakkal és titulatus possessor Orban Antal úrral megállították, onnan a mi vélekedésünk is az, hogy a határnak felit közepes jóságúnak, a más felit alábbvalónak lehet venni.

Hogy ezen vallomások általunk lelkiesméretünk és hitünk szerint anyai magyar nyelven felvettük, felolvastuk és a fennírt béesküt bírák és lakosok által edgyik is írni nem tudván, egyiken kívül, minthogy a hellységnek pecséttye nem volt, kezek keresztvonásokkal meg erösítették, usuális pecsétünk és subscriptiónk által recognoscályuk.

Költ a fenn írt hellyen, esztendőben és napon.

Ambrus János falusbíró +

Ambrus Ferencz +

Balás András mp.

Vas Elek +

Vas András +

Modi János +

Vas Ferencz +

Sz. Léleki Pakot Elek mp. [gyürüs pecsét]

és KKedei Ifj. Imreh György mp. [gyürüs pecsét]

exequens urbarialis conscriptorok 


\section{AZ ERDÉLYI MÚZEUM-EGYESÜLET KIADÁSÁBAN MEGJELENT:}

\section{Erdélyi Múzeum}

Az Erdélyi Múzeum-Egyesület Bölcsészet-, Nyelv- és Történettudományi,

valamint Jog-, Közgazdaság- és Társadalomtudományi Szakosztályainak közlönye:

55. kötet. 1993. 1-2. és 3-4. füzet; 56. kötet. 1994. 1-2. és 3-4. füzet; 57. kötet. 1995. 1-2. és

3-4. füzet; 58. kötet. 1996. 1-2. füzet, 58. kötet. 1996. 3-4. füzet, 59. kötet. 1997. 1-2. füzet és

3-4. füzet, 60. kötet. 1998. 1-2. füzet.

\section{Múzeumi Füzetek}

Az Erdélyi Múzeum-Egyesület Természettudományi és Matematikai

Szakosztályának Közleményei: 2. 1993.; 3. 1994.; 4. 1995.; 5. 1996.; 6. 1997.; 7. 1998.

\section{Orvostudományi Értesítő}

Az Erdélyi Múzeum-Egyesület Orvostudományi Szakosztályának közleményei: 64. kötet. 1991.;

65. kötet. 1992.; 66. kötet. 1993.; 67. kötet. 1994.; 68. kötet 1995.; 69. kötet. 1996.; 70. kötet. 1997.

\section{Müszaki Tudományos Füzetek}

1. Jodál Endre: Számítástechnika az ezredforduló küszöbén.

2. Pálfalvi Attila: Porkohászat.

\section{Erdélyi Tudományos Füzetek}

213. Emlékezés Széchenyi Istvánra Erdélyben 1991-ben.

Csetri Elek, Fábián Ernő, Benkő Samu, Nagy György írásai.

217. Bura László: A Szatmári Református Kollégium és diákjai (1610-1852).

218. Az Erdélyi Magyar Nyelvmívelő Társaság 200 éve (1793-1993). A marosvásárhelyi tudományos ülésszakon elhangzott előadások.

219. Emlékezés Kossuth Lajosra Erdélyben 1994-ben. Az EME 1994. április 16-án tartott emlékülésén elhangzott előadások.

220. Szentkatolnai Bálint Gábor.

Borcsa János, Bodor András, Péntek János, Berta Árpád, Bakk Pál és Senga Toru tanulmányai.

222. Jakó Zsigmond: Ezerszáz esztendő.

223. Benkő Elek-Demeter István-Székely Attila: Középkori mezőváros a Székelyföldön.

224. Egyed Emese: Levevék fejemről Múzsák sisakomat. Barcsay Ábrahám költészete.

225. Coroi Artúr: Adalékok Háromszék iskolatörténetéhez.

\section{Erdélyi Történelmi Adatok}

VI. 1. Wolf Rudolf: Torda város tanácsi jegyzőkönyve 1603-1678.

\section{Romániai Magyar Bibliográfiák}

1. Romániai magyar könyvkiadás 1944-1949.

2. Romániai magyar könyvkiadás 1950-1953.

Benedek István: Repülőmodellezés Kolozsváron.

Deé Nagy Anikó: A könyvtáralapító Teleki Sámuel.

Entz Géza: Erdély építészete a 11-13. században.

Entz Géza: Erdély építészete a 14-16. században.

Emlékkönyv Jakó Zsigmond születésének nyolcvanadik évfordulójára.

Gábos Zoltán: Termodinamika. Fenomenológiai rész.

Kékedy László: Műszeres analitikai kémia.

Sepsi Árpád-Kohl István: A kárpáti barnamedve. 